
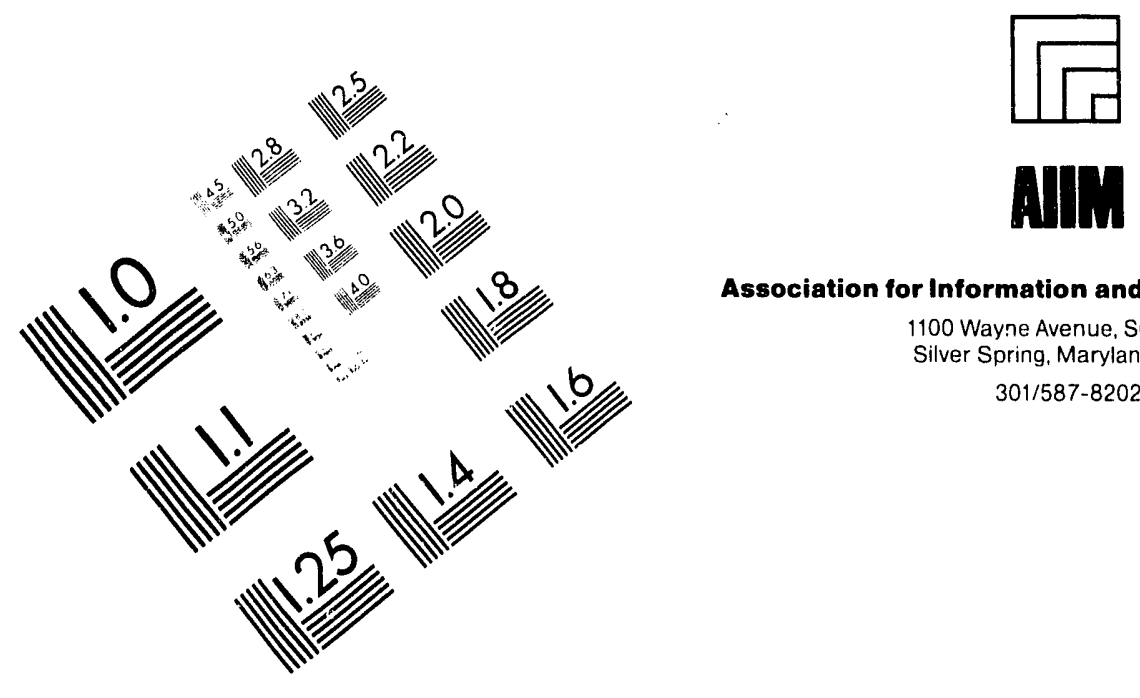

Association for Information and Image Management

1100 Wayne Avenue. Suite 1100

Silver Spring, Maryland 20910

301/587-8202

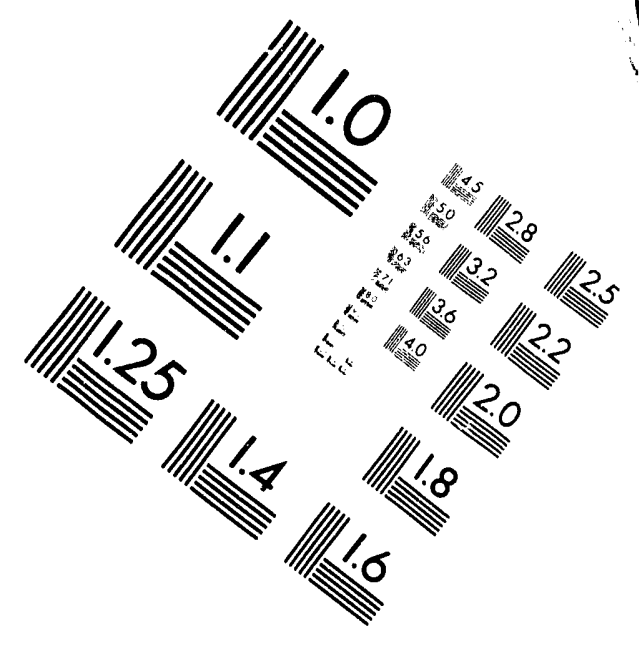

\title{
Centimeter
}

$\begin{array}{llllllllllllllll}1 & 2 & 3 & 4 & 5 & 6 & 7 & 8 & 9 & 10 & 11 & 12 & 13 & 14 & 15 & 15\end{array}$

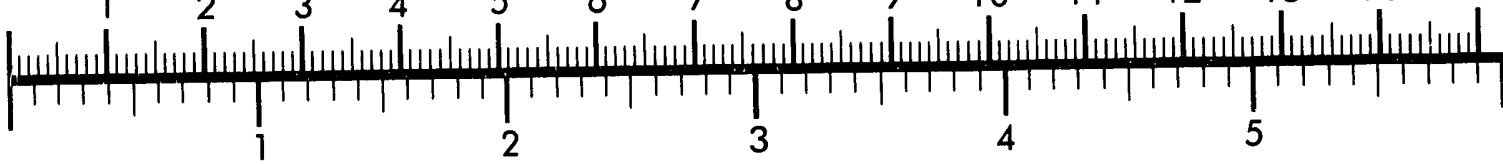
Inches
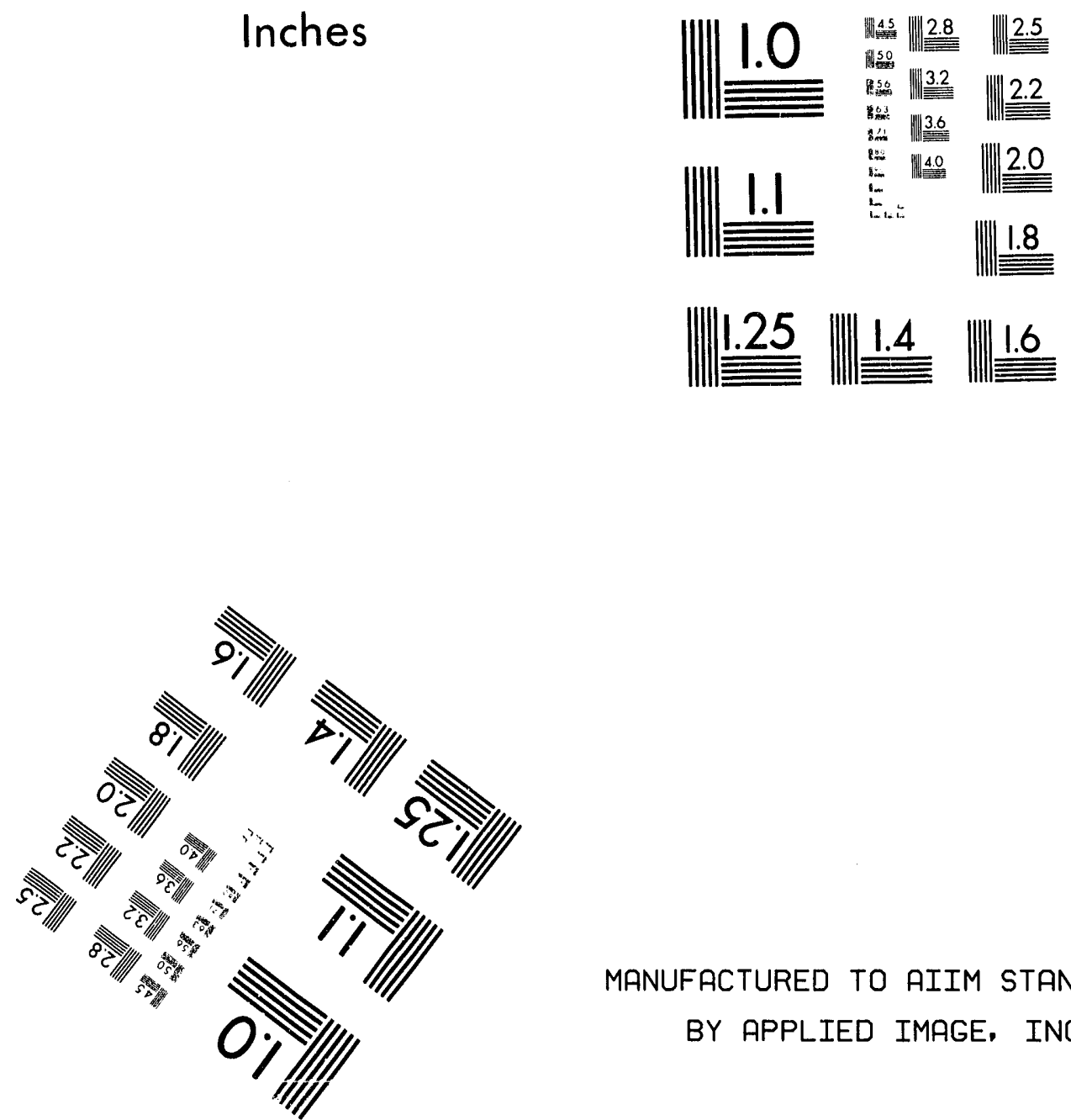

MANUFACTURED TO AIIM STANDARDS

BY APPLIED IMAGE, INC.

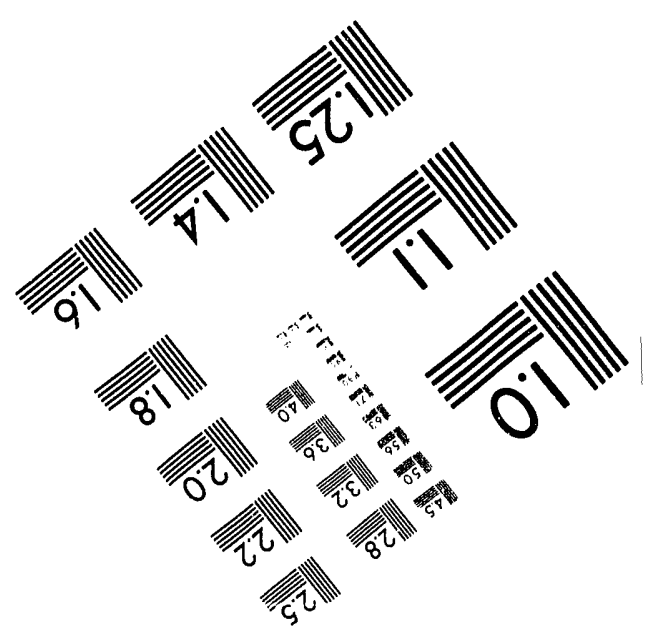



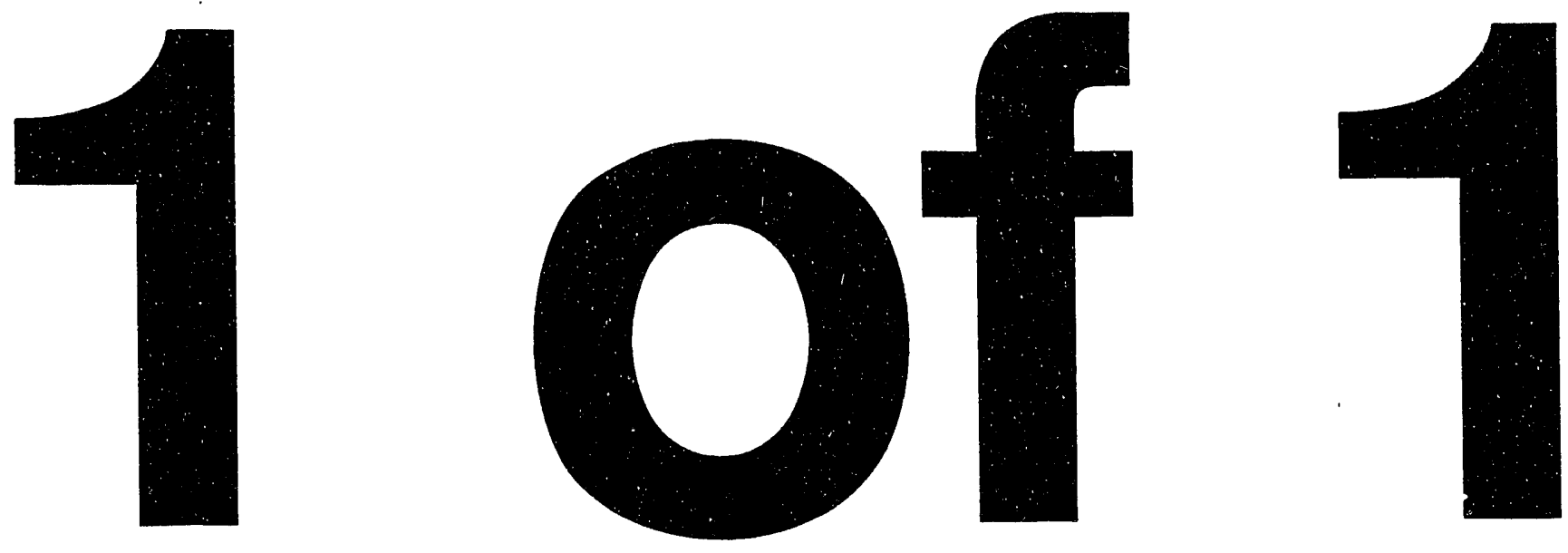
GRI-91/0158

LBL-30376

$\mathrm{UC}-000$

\section{ANALYSIS OF THE IMPACTS OF ENERGY CONSERVATION CODES IN NEW SINGLE-FAMILY HOMES}

TOPICAL REPORT

\section{Prepared by}

R.L. Ritschard, J.W. Hanford, and A.O. Sezgen

Lawrence Berkeley Laboratory

Applied Science Division

Berkeley, CA 94720

For

Gas Research Institute

GRI Contract No. 5086-800-1318

GRI Project Manager

James M. Fay

Residential/Commercial

Technology Analysis Program

Through U.S. Department of Energy

under Contract No. DE-AC03-76SF00098

December 1992
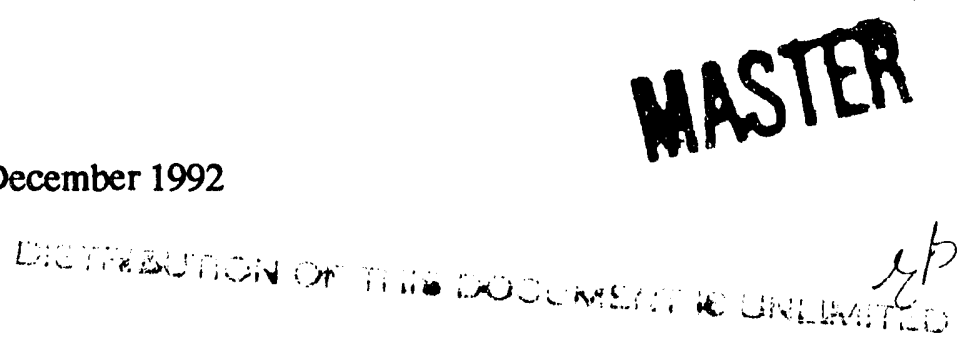


\section{GRI DISCLAIMER}

LFGAL NOTICE: This report was prepared by Lawrence Berkeley Laboratory as an account of work sponsored by Gas Research Institute (GRI). Neither GRI, members of GRI, nor any persons acting on behalf of either:

1. Makes any warranty of representation, expressed or implied, with respect to the accuracy, completeness, or usefulness of the information contained in this report, or that the use of any apparatus, method, or process disclosed in this report may not infringe on privately owned rights; or

2. Assumes any liability with respect to the use of, or for damages resulting from the use of, any information, apparatus, method, or process disclosed in this report.

This report is available from National Technical Information Service, U. S. Department of Commerce, 5285 Port Royal Road, Springfield, VA 22161. 


\section{RESEARCH SUMMARY}

TITLE

CONTRACTOR

PRINCIPAL

INVESTIGATOR

REPORT

OBJECTIVE

TECHNICAL PERSPECTIVE
Analysis of the Impacts of Energy Conservation Codes in New Single-Family Homes

Lawrence Berkeley Laboratory

Applied Science Division

1 Cyclotron Road

Berkeley, California 94720

R.L. Ritschard

May 1990 - May 1991

To analyze the energy implications of two thermal codes (ASHRAE 90.2P and 1990 Model Energy Code) and the National Appliance Energy Conservation Act (NAECA) of 1987 and Amendments of 1988 on energy use in prototypical new single-family buildings in the U.S.

Within all 50 states, some form of code or standard for energy conservation in new building construction has been introduced. These codes or standards are of special importance to GRI because when fully implemented they will influence the heating and cooling requirements of single-family building types. The study provides estimates of the impacts of these standards on annual and peak energy usage for space heating and cooling and annual energy usage for water heating and nonHVAC end uses.

RESULTS The two thermal standards, ASHRAE 90.2 and Model Energy Code, and appliance and equipment efficiency requirements (NAECA) can be effective in reducing annual energy use for both natural gas and electricity. In many U.S. climates this will result in significant reductions in annual energy costs. The thermal codes are not effective in lowering cooling energy use since they are mostly "envelope" codes and not equipment codes. 
TECHNICAL APPROACH

PROJECT IMPLICATIONS
Single-family prototypical buildings with 1990 s construction characteristics were simulated in 16 base cities representative of U.S. climates using a state-of-the-art hourly building energy code, DOE-2.1D. These simulations were performed with and without the requirements of the two thermal codes and provisions of the NAECA. Domestic hot water usage and non-HVAC electricity use were also calculated using standard engineering methods. The results include annual and peak energy consumption for natural gas and electricity end-uses for each prototype and base city. In addition, annual cost savings are calculated for a few selected cities with high natural gas or electricity usage.

The energy impacts of two building energy codes and the NAECA on 1990s prototypical single-family homes will provide useful information to GRI's R\&D programs about natural gas requirements in new residences. These annual and peak energy requirements for space heating and cooling, water heating, and non-HVAC end uses will provide insights for further analysis into important issues related to the use of energy technologies in the single-family homes.

\section{Project Manager}

Mr. James M. Fay

Residential/Commercial

Technology Analysis 


\section{Table of Contents}

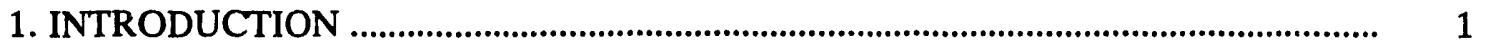

2. DESCRIPTION OF CODES …................................................................................. 3

THERMAL CODES ...................................................................................................... 3

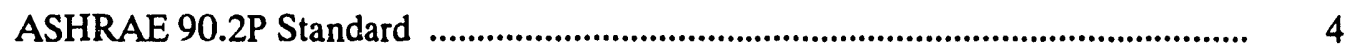

Model Energy Code .................................................................................................... 4

EQUIPMENT AND APPLIANCE CODES ...................................................... 6

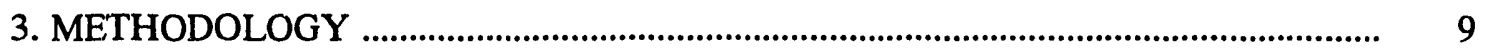

SELECTION OF BASE CITIES ................................................................... 10

STRUCTURAL ASSUMPTIONS _.................................................................. 10

Building Prototypes ............................................................................................... 10

Building Geometry ...................................................................................................... 15

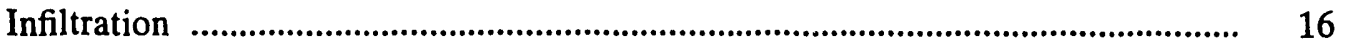

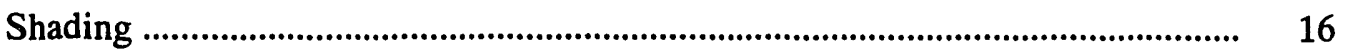

Foundation Heat Loss ............................................................................ 17

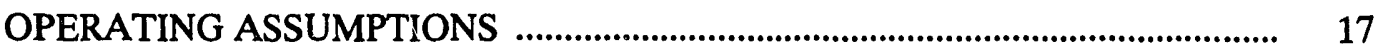

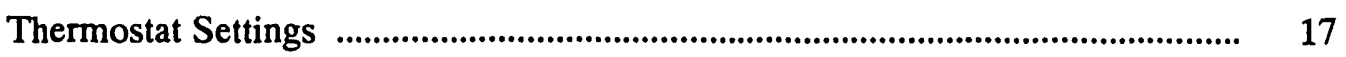

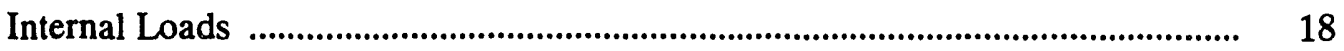

Non-HVAC Energy Consumption Methodology .................................................. 20

Domestic Hot Water Methodology ............................................................................... 20

HVAC Energy Use Calculation ................................................................................... 24

METHODS FOR CALCULATING ENERGY COST SAVINGS .......................... 24

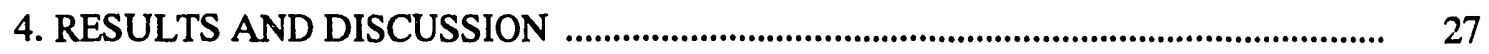

STANDARDS IMPACTS ON NATURAL GAS CONSUMPTION ...................... 28

Effects on Gas Space Heating Consumption ............................................................ 28

Effects on Appliance Gas Use .................................................................................... 35

STANDARDS IMPACTS ON ELECTRICITY CONSUMPTION .......................... 35

Effects on Cooling Energy Consumption ......................................................... 35 
Effects on Non-HVAC Electricity Consumption .................................................. 38

SUMMARY OF INTERNAL GAINS INTERACTIONS …...................................... 39

TOTAL HOUSE ENERGY SAVINGS …............................................................ 39

ENERGY COST SAVINGS ............................................................................ 41

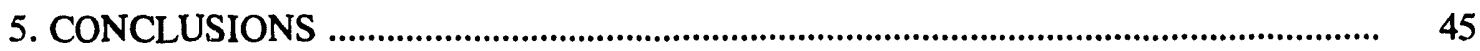

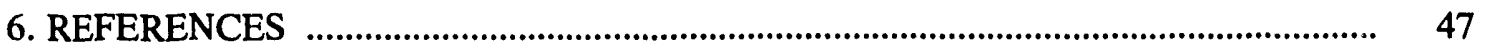

APPENDIX A: Heating and Cooling Loads Tables ........................................................ 51

APPENDIX B: Requirements of the Proposed ASHRAE 90.2 Standard ............................ 55

APPENDIX C: Requirements of the Model Energy Code ................................................... 59

-vi- 


\section{LIST OF TABLES}

Table No.

Title

Page No.

1 ASHRAE 90.2P Code Thermal Integrity Requirements (R-values)

2 Model Energy Code Thermal Integrity Requirements (R-values)

3 Appliance Energy Use and Equipment Efficiency

Improvements Under NAECA

$4 \quad$ Base Cities for Building Prototypes and Climates

5 General Specifications for Prototype Buildings

6 Building Envelope Parameters for Base Case and Code Compliance Buildings

71984 RECS Data Tape Results for Single-Family Detached DwellingsAppliance Saturations and Types by Census Division 19

8 Annual Appliance and Lighting Energy Use 20

9 Estimated Non-HVAC Electric and Gas Consumption and Internal Loads 22

10 Average Air and Well Temperatures for Base Cities 23

11 HVAC Equipment Efficiency Assumptions 24

12a Calculation of Natural Gas Energy Costs 26

12b Calculation of Electric Energy Costs 26

13 Annual Hot Water Use and Water Heat Energy

by Fuel and Location $\quad 28$

14 End Use Energy Consumption Under Efficiency Standard Combinations 29-31

15 Change in Heating and Cooling Loads and Energy Use from Changes in Internal Gains $\quad 40$

16 Base Case Energy Use and Total House Energy Savings from Standards Measures $\quad 41$

17 Annual Energy Cost Savings for Natural Gas 44

18 Annual Energy Cost Savings for Electricity 44 


\section{LIST OF FIGURES}

Figure No.

Title

Page No.

1 Average Floor Area for New Construction

U.S. Single-Family Buildings, 1980-1989

2 Construction Type for New Construction

U.S. Single-Family Buildings, 1980-1989 13

3 Internal Loads Profiles for Prototype Buildings 21

$4 \quad$ Space Heating Gas Use with Envelope Standards 33

5 Space Heating Gas Use with NAECA Standards 33

6 Space Heating Gas Use with Combination Standards 34

$7 \quad$ Appliance Gas Use with NAECA Standards 34

8 Cooling Electricity Use with Envelope Standards 36

9 Cooling Electricity Use with NAECA Standards 36

10 Cooling Electricity Use with Combination Standards 37

11 Appliance Electricity Use with NAECA Standards 37

12 Change in Heating and Cooling Loads with Change in Internal Gains $\quad 40$

13 Annual Energy Cost Savings for Natural Gas 43

14 Annual Energy Cost Savings for Electricity 43 


\section{EXECUTIVE SUMMARY}

Within the 50 states some form of federal code or standari for energy conservation in new building construction is typically incorporated into state and local codes. Two of these codes, the Model Energy Code (MEC) and the proposed ASHRAE standard 90.2P are of special importance to the residential data base developed by the Gas Research Institute (GRI) because they influence thermal requirements and have either been recently updated or will be revised in 1992.

In this study, we evaluate the impacts of these two thermal codes on the energy performance and energy consumption of prototypical new single-family buildings. Base case buildings, with characteristics typical of current building practices, are modified to meet the thermal envelope standards and are simulated with the DOE-2.1D building energy simulation program. In addition, we also model the effects of appliance and heating and cooling equipment efficiencies promulgated under the National Appliance Energy Conservation Act (NAECA) of 1987 (P.L. 100-12) and of the NAECA Amendments of 1988 (P.L. 100-357).

We compare heating and cooling loads and energy use for the prototypical house for several cases: the base case, with 1980s vintage thermal envelope and appliance and equipment efficiencies; with ASHRAE 90 thermal requirements; with Model Energy Code thermal requirements; with NAECA appliance and HVAC efficiencies; and with combinations of the ASHRAE 90 Standard or Model Energy Code and the NAECA appliance and equipment efficiency improvements. The results provide a glimpse of how these standards will affect future end-use energy consumption in new single-family buildings, both alone and in combination as they would occur in the "real" world.

The simulations and other calculations suggest that these new standards could lead to significant changes in energy consumption for particular end uses, with the following major conclusions.

- The greatest annual energy savings for both natural gas and electricity are from the combination of the ASHRAE Standard and full provisions of the NAECA. In the most extreme climates, the standards will potentially reduce space heat energy use by $31 \%$, or $42 \mathrm{MMBtu}$ for natural gas heat, and can reduce space cooling energy use by up to $20 \%$, or $1032 \mathrm{kWh}$ for electric air-conditioning.

- The requirements of the combined ASHRAE Standard and the appliance and equipment provisions in NAECA also provide large peak savings of natural gas and electricity. Gas peak savings for space heat reach $13.6 \mathrm{kBtu} / \mathrm{hr}$ and electricity peak savings for cooling reach $0.8 \mathrm{~kW}$. 
- The ASHRAE 90 Standard alone has the largest impact on space heating energy use, particularly in colder climates. The maximum annual gas space heat savings for ASHRAE are 37.9 MMBtu in Minneapolis, the coldest climate studied. Typical savings in colder climates are about $22 \mathrm{MMBtu} / \mathrm{yr}$, or $27 \%$. The ASHRAE standard typically has more stringent requirements than the MEC, and thus is more effective in reducing gas space heating energy usage than the Model Energy Code in all but one location (Fort Worth). In some locations, the MEC did not challenge current construction practices.

- In all locations, the appliance standards of the NAECA slightly increase annual space heating gas use by 2 to $4 \%$ and slightly decrease cooling electricity consumption by 4\%. These changes arise from a decrease in internal heat gains from the more efficient appliances.

- Improvements in furnace efficiency under the NAECA standards save $9 \%$ in both annual and peak natural gas consumption for space heating in all climates.

- Improvements in air-conditioner efficiency (i.e., changes in SEER) in the NAECA equipment standards reduce space cooling energy consumption by $10-14 \%$, or up to $750 \mathrm{kWh} / \mathrm{yr}$, annually in the hotter climates.

- The thermal envelope standards have a varied effect on cooling. They reduce energy consumption in the south and west, and slightly increase cooling in the north and midwest. The increase in electricity use is a result of the new balance point temperature established by the insulation levels in the colder climates. In total, changes in cooling energy use from the envelope standards are small compared to the equipment standaids.

- The non-HVAC electricity savings resulting from the NAECA are $10 \%$ to $15 \%$ of the base case appliance electricity consumption, or an annual average of about 1125 $\mathrm{kWh}$. The appliance savings are greater than the space cooling savings in all climates.

- Rate schedules can influence the effectiveness of the thermal and appliance standards. That is, cost savings may be greater even though the annual energy savings are not.

These standards, if fully implemented, could significantly change end-use energy requirements in new single-family buildings. The overall conclusions are that new thermal standards and appliance and equipment efficiency requirements can be effective in reducing total annual energy use for both natural gas and electric heating, cooling, and appliance end uses, and in turn, can substantially reduce annual energy costs in many U.S. climates. 
INTRODUCTION

Within the 50 states some form of federal code or standard for energy conservation in new building construction is typically incorporated into state and local codes. There are several existing energy codes that cover residential buildings, typically applying to the singlefamily and low-rise multifamily building types. Two of these codes are of special importance to the residential data base developed by the Gas Research Institute (GRI) because they influence thermal requiremenis and have either been recently updated or will be revised in 1992. The Model Energy Code (MEC), developed by the Council of American Building Officials (CABO) with assistance from the Building Officials and Code Administrators International, Inc. (BOCA), the International Conference of Building Officials (ICBO), the Southern Building Code Congress International, Inc. (SBCCI), and the National Conference of States on Building Codes and Standards, Inc (NCSBCS), was updated in 1989 to provide simplified nomographs for making thermal envelope "tradeoffs" between wall and roof/ceiling requirements for new residential buildings. ${ }^{1}$ The technical requirements of the MEC were also updated from the previous 1983 version.

A second equally important building energy standard is ASHRAE 90-85 (Energy Efficient Design of New Low-rise Residential Buildings) developed by the American Suciety of Heating, Refrigerating and Air-conditioning Engineers, Inc. An updated version of the ASHRAE 90 Standard is currently being reviewed and may be adopted in $1992 .{ }^{2}$ The revised ASHRAE 90 Standard (90.2P) will consider, for the first time, both heating and cooling requirements. In previous versions, only space heating, along with some minimum requirements for water heating and lighting, are considered. ASHRAE 90.2P will also be based on regional energy costs as well as climate variations. Only climate variations had been considered in previous versions. The ASHRAE standards continue to serve as technical bases for state building energy codes.

In this study, we evaluate the impacts of the requirements in the two thermal envelope standards on the energy performance of prototypical new single-family buildings. Base case construction and modified standards buildings are simulated with the DOE-2.1D building energy simulation program. The base case building characteristics and operating conditions are designed to emulate new buildings which will be built in the 1990s with no new standards in place and no increase in thermal envelope, appliance, or equipment efficiencies. Thus, the base case is an estimated 1990 vintage building in terms of building size, shape, etc., yet with insulation characteristics typical of buildings built in the 1980s, or between 1980 and 1989. In addition, we also model the effects of appliance and heating and cooling equipment efficiency standards promulgated under the National Appliance Energy Conservation Act (NAECA) of 1987 (P.L. 100-12) and of the NAECA Amendments of 1988 (P.L. 100-357). ${ }^{4}$ The impacts of 
the NAECA are evaluated separately (i.e., improved appliance efficiency and improved efficiency of space conditioning equipment) and also in combination with either the Model Energy Code or the ASHRAE 90.2 Standard.

The overall focus of this work is to demonstrate what changes can be expected in new single-family building types with regard to end use (heating, cooling, water heating, and nonHVAC $\ddagger$ energy) and total building energy consumption and peak HVAC energy use. In analyzing the effects of the ASHRAE 90 Standard, 16 cities are studied that are part of the GRI single-family loads data base, while only a subset (7) of these cities were used for the study of the Model Energy Code. The cities for which the MEC impacts are analyzed are in states where the MEC has been adopted, either in full or in part, as part of the state building code.

In the report, we compare heating and cooling loads and energy use for the prototypical house for several cases: the base case, with 1980s vintage thermal and equipment efficiencies; with ASHRAE 90 thermal requirements; with Model Energy Code thermal requirements; with NAECA appliance and HVAC efficiencies; and with combinations of the ASHRAE 90 Standard or Model Energy Code and the NAECA appliance and equipment upgrades. These comparisons offer a way to evaluate the energy effects of the thermal and appliance standards alone as well as in combination as they exist in the "real" world.

The remainder of the report is organized into four additional sections. First, we present the nature of the various thermal envelope, appliance, and efficiency standards as they affect each prototypical building type in each location. This section provides a list of the assumed thermal conditions or appliance and equipment efficiencies for each standard. Second, we summarize the methods and technical approach, including discussions of the selection of weather tapes and base cities, structural assumptions, and building operating conditions. Next, we present the results for each energy standard or a combination of standards assumed in the overall analysis. The results are discussed in light of the impacts of the various building standards on annual heating and cooling energy use and peak heating and cooling loads and energy use. Finally, in the last section, we present the major conclusions of this study.

¥HVAC denotes heating, ventilation, and air-conditioning systems 


\section{2 \\ DESCRIPTION OF CODES}

To more fully characterize the end-use impacts of the standards considered in this project, we consider each standard separately, and even parts of each standard separately. This section defines the requirements in each standard that we consider. For example, we define the ASHRAE and MEC codes as "thermal" or "envelope" standards. That is because the primary component of these codes is minimum thermal requirements for the major building heat gain and loss components such as roofs, walls, floors, foundations, windows, and infiltration. As we discuss below, ASHRAE and MEC both contain standards for HVAC equipment and water heater efficiencies. However, we consider the furnace and air-conditioner requirements to be "equipment" standards and the water heater standards as an "appliance" standard. Standards

enacted under NAECA include hoth minimum efficiency requirements for "equipment" -- furnaces, air-conditioners, and heat pumps -- as well as typical household appliances such as refrigerators, clothes washers, water heaters and television sets. We distinguish between the two because they affect end-use energy consumption in different ways.

\section{THERMAL CODES}

The thermal codes considered here are national standards; they are meant to serve as technical and programmatic bases for energy codes throughout the U.S. even though the requirements vary between regions. Thus, the requirements contained in either the ASHRAE standard or the MEC are likely to be later incorporated in state building energy standards.

ASHRAE 90.2P is a proposed update to the ASHRAE 90-1985 standard, which itself was an improved version of ASHRAE 90A-1980. This family of national energy conservation standards is the basis for almost all state and local government building energy codes. In some cases, the ASHRAE standard is adopted in full. In others, some of the ASHRAE standard provisions are modified to suit local conditions. ${ }^{5}$

The Model Energy Code is also updated every several years. The first standard, entitled "Model Code for Energy Conservation in New Building Construction 1977" (MCEC) was based on the technical provisions of ASHRAE 90-75. The next major version, "Model Energy Code 1983", was based on ASHRAE 90A-1980. The latest Model Energy Code, which the following work will analyze, is a version released in 1989 and still maintains ASHRAE 90A as its technical basis. ${ }^{5}$ Thus, the Model Energy Code revisions follow revisions to the ASHRAE standard, and lag it in time by two to three years. The Model Energy Code (MEC) is adopted by reference in the Uniform Building Code (UBC). 


\section{ASHRAE 90.2P Standard}

The purpose of the ASHRAE 90.2P standard is "to provide design requirements for energy efficient new residential buildings." For the building stock, it covers residential buildings of three stories or less and manufactured housing. In terms of the systems covered in the standard, it includes specifications on the building envelope, space heating equipment, space cooling equipment and domestic water heating. Furthermore, it allows for two methods of compliance: a prescriptive approach and a systems analysis approach. ${ }^{2}$

In this analysis, we model the code as solely a prescriptive code. Because the systems analysis approach allows a combination of many varied conservation strategies, we chose to simplify the approach by applying the prescriptive code to the building prototypes on a component-by-component basis. Since the systems analysis approach allows for trading undercompliance on one building component with overcompliance on another, the final energy consumption should be roughly equivalent. Our assumption that individual components would each be upgraded independently to meet the standard, while the other components maintained at current levels, also introduces some error, although we found that where the base case currently meets or exceeds the minimum standard, it is only by a small amount. As previously noted, we consider only the building envelope provisions of the ASHRAE 90 standard. The standards which apply to space heating and cooling equipment and water heating appliances and systems are included as part of the equipment code analysis under NAECA.

Table 1 provides the essential thermal requirements of ASHRAE 90.2P for single-family detached buildings in each of the climate zones under investigation. Requirements for the full range of building envelope components are given in Appendix B. The R-values and U-values are taken from nomographs and reflect the heating degree days and cooling degree hours of the local climate. For each building component two nomographs are given; one for buildings with the ducts in the conditioned space, and one for ducts outside of the conditioned space. For this analysis we chose the latter since it is the more typical construction practice. Since the requirements are more stringent when the ducts are outside the conditioned space, we may be slightly overestimating the savings due to the envelope requirements.

The ASHRAE code also gives requirements for air leakage. However, these are based on test values for building components such as windows and doors and not on whole-building or component performance estimates in real-life conditions. The method used in estimating infiltration in the base case and standards case buildings will be discussed in the following chapter.

\section{Model Energy Code}

The intent and scope of the Model Energy Code are similar to that of ASHRAE 90.2. It covers the same building types, components, and systems. Furthermore, it also allows for multiple methods of compliance: a systems approach, a component performance approach, and 
Table 1. ASHRAE 90.2P Code Thermal Integrity Requirements (R-Values)*

\begin{tabular}{|c|c|c|c|c|c|c|c|c|}
\hline City & HDD65** & $\mathrm{CDH} 74^{* * *}$ & Wall & Roof $\dagger$ & Floortt & $\begin{array}{c}\text { Bsmt } \\
\text { Wall } \neq\end{array}$ & Slabł‡ & $\begin{array}{l}\text { Window } \\
\text { (U-value)§ }\end{array}$ \\
\hline Boston MA & 5596 & 5358 & 16 & 28 & 21 & $16 \mathrm{~F}$ & $8(2)$ & 0.36 \\
\hline New York NY (JFK) & 5171 & 7634 & 16 & 28 & 21 & $16 \mathrm{~F}$ & $5(2)$ & 0.36 \\
\hline Chicago IL & 6459 & 6606 & 16 & 28 & 21 & $16 \mathrm{~F}$ & $8(2)$ & 0.36 \\
\hline Minneapolis MN & 8010 & 6806 & 24 & 48 & 21 & $16 \mathrm{~F}$ & $8(2)$ & 0.36 \\
\hline Kansas City MO & 4814 & 20256 & 16 & 28 & 21 & $16 \mathrm{~F}$ & $5(2)$ & 0.36 \\
\hline Washington DC (Dulles) & 5005 & 7715 & 16 & 28 & 21 & $16 \mathrm{~F}$ & $5(2)$ & 0.36 \\
\hline Atlanta GA & 3025 & 16803 & 16 & 28 & 14 & $6 \mathrm{~F}$ & $4(2)$ & 0.87 \\
\hline Miami FL & 198 & 39401 & 16 & 28 & 14 & $0.6 \mathrm{~F}$ & $4(2)$ & 1.31 \\
\hline Dallas-Ft Worth TX & 2420 & 36294 & 16 & 28 & 14 & $5 \mathrm{~F}$ & $5(2)$ & 0.87 \\
\hline New Orleans LA & 1490 & 28605 & 16 & 28 & 14 & $5 \mathrm{~F}$ & $4(2)$ & 0.87 \\
\hline Denver CO & 6023 & 5908 & 16 & 28 & 21 & $16 \mathrm{~F}$ & $8(2)$ & 0.36 \\
\hline Albuquerque NM & 4415 & 11012 & 16 & 28 & 21 & $16 \mathrm{~F}$ & $5(2)$ & 0.36 \\
\hline Phoenix AZ & 1444 & 54404 & 16 & 28 & 14 & $5 F$ & $5(2)$ & 0.87 \\
\hline Seattle WA (urban) & 4684 & 897 & 16 & 28 & 21 & $16 \mathrm{~F}$ & $5(2)$ & 0.36 \\
\hline San Francisco CA & 3078 & 216 & 16 & 28 & 14 & $6 \mathrm{~F}$ & $4(2)$ & 0.87 \\
\hline Los Angeles CA (LAX) & 1595 & 4306 & 16 & 20 & 14 & $5 \mathrm{~F}$ & - & 0.87 \\
\hline
\end{tabular}

* All values are for ducts outside the conditioned space. $\mathrm{R}$-value in $\mathrm{hr}-\mathrm{ft}^{2}-{ }^{\circ} \mathrm{F} / \mathrm{Btu}$.

** HDD65 is heating degree-day, base $65^{\circ} \mathrm{F}$

*** CDH74 is cooling degree-hour, base $74^{\circ} \mathrm{F}$

$\dagger$ Roof values are for ceilings with attics.

†† Floor values are for floors over unconditioned space.

$\ddagger$ Basements with exterior insulation. $F=$ full basement height.

$\ddagger$ Number in parentheses is depth of insulation in feet.

$\S$ Fenestration U-value including framing.

specified acceptable practice. ${ }^{1}$ As with the ASHRAE analysis, we model the code as solely a prescriptive code. We also consider only the building envelope provisions of the MEC, neglecting the HVAC system and infiltration requirements of the code. The HVAC requirements are considered as NAECA equipment standards. The infiltration assumptions are considered in the next chapter.

Table 2 gives the important requirements of the Model Energy Code, while the full list is given in Appendix C. These requirements are also taken from nomographs. However, the Model Energy Code requirements are based only on the heating degree days of the climate. Note that the wall requirements are an overall average of wall and window conductance. This allows tradeoffs between wall insulation, window $u$-value, and window and wall area. 
Table 2. Model Energy Code Thermal Integrity Requirements (R-Values)

\begin{tabular}{|lr|ccccc|}
\hline City & HDD65* $^{*}$ & Wall $^{* *}$ & Roof & Floort & Bsmt Wall $+\dagger$ & Slab $\neq$ \\
\hline Boston MA & 5596 & 8 & 37 & 20 & $10 \mathrm{~F}$ & $5(2)$ \\
New York NY (JFK) & 5171 & 8 & 34 & 20 & $11 \mathrm{~F}$ & $5(2)$ \\
Chicago IL & 6459 & 9 & 40 & 20 & $11 \mathrm{~F}$ & $5(4)$ \\
Minneapolis MN & 8010 & 9 & 40 & 20 & $11 \mathrm{~F}$ & $6(4)$ \\
Kansas City MO & 4814 & 7 & 32 & 20 & $10 \mathrm{~F}$ & $4(2)$ \\
Washington DC (Dulles) & 5005 & 8 & 33 & 20 & $10 \mathrm{~F}$ & $5(2)$ \\
Atlanta GA & 3025 & 6 & 25 & 20 & $7 \mathrm{~F}$ & $4(2)$ \\
Miami FL & 198 & 3 & 20 & 13 & - & - \\
Dallas-Ft Worth TX & 2420 & 6 & 23 & $14 \mathrm{~F}$ & 7 & - \\
New Orleans LA & 1490 & 5 & 21 & 14 & $6 \mathrm{~F}$ & - \\
Denver CO & 6023 & 8 & 40 & 20 & $11 \mathrm{~F}$ & $5(4)$ \\
Albuquerque NM & 4415 & 7 & 30 & 20 & $10 \mathrm{~F}$ & $4(2)$ \\
Phoenix AZ & 1444 & 5 & 21 & 14 & - & - \\
Seattle WA & 4684 & 7 & 31 & 20 & $10 \mathrm{~F}$ & $4(2)$ \\
San Francisco CA & 3078 & 6 & 25 & 20 & $7 \mathrm{~F}$ & $4(2)$ \\
Los Angeles CA (LAX) & 1595 & 5 & 22 & 14 & $6 \mathrm{~F}$ & - \\
\hline
\end{tabular}

${ }^{*}$ HDD65 is heating degree-day, base $65^{\circ} \mathrm{F}$

** Overall wall $\mathrm{R}$-value, including window and opaque portions.

+ Floor values are for floors over unconditioned spaces.

$\dagger+F=$ full basement height.

$¥$ Number in parentheses is depth of insulation in feet.

\section{EQUIPMENT AND APPLIANCE CODES}

The National Appliance Energy Conservation Act (NAECA) was enacted in 1987 and updated by the NAECA Amendments of 1988. These provisions mandate minimum energyefficiency standards for most major household appliances and space conditioning equipment. The Act included standards for many household appliances and equipment, and established a procedure for updating the standards in future years. The first major efficiency requirements took effect in 1990, and covered furnaces, refrigerators, freezers, room air conditioners, and water heaters. In 1992 standards will be applied to central air conditioners and heat pumps, and in 1993 new refrigerator and freezer standards will become effective. NAECA allows for periodic updates, which will likely continue into the next century. ${ }^{6}$

For this study, we analyze the effect of the NAECA appliance and equipment standards separately and combined. The appliance standards will not only affect baseload energy use in the building but will also impact heating and cooling energy consumption by changing the internal gains inputs into the building. The appliances considered under NAECA which are included in this study are refrigerators, freezers, dishwashers, clothes washers and dryers, ranges and ovens, and water heaters. Also included in our calculation of appliance 
consumption and internal gains are televisions and other small appliances, which are not yet affected by NAECA. We also calculate electricity use for lighting, but NAECA only regulates fluorescent light ballasts which should have little effect on residential lighting loads. We also model the effect of NAECA's furnace and air conditioner standards on heating and cooling energy use. For the purposes of this study, we consider the 1990s prototypical house will meet all standards under NAECA that will be in place by 1995, rather than staggering them as they are enacted.

Typically, the standards set for these appliances will be a function of capacity or appliance size. Thus, defining one typical energy use value for all appliance sizes and types is not possible. We used average energy use values for average 1980 stock and new 1995 appliances derived from the LBL Residential Energy Model. ${ }^{7}$ The values used in this study are provided below in Table 3.

Table 3. Appliance Energy Use and Equipment Efficiency Improvements Under NAECA

\begin{tabular}{|llccl|}
\hline Appliance or & & $1980 \mathrm{~s}$ & 1995 & \\
Equipment & Units & Average & NAECA & Comments \\
\hline Refrigerators & $\mathrm{kWh}$ & 1125 & 705 & \\
Electric Cooking & $\mathrm{kWh}$ & 1200 & 1010 & \\
Dishwasher & $\mathrm{kWh}$ & 200 & 160 & Does not include water heat \\
Clothes Washer & $\mathrm{kWh}$ & 110 & 95 & Does not include water heat \\
Electric Dryer & $\mathrm{kWh}$ & 900 & 750 & \\
Freezer & $\mathrm{kWh}$ & 950 & 475 & \\
\hline Gas Cooking & MMBtu & 8.99 & 4.89 & \\
Gas Dryer & MMBtu & 4.07 & 3.21 & \\
\hline Water Heater (Gas) & EF & 51.2 & 56.1 & \\
Water Heater (Electric)EF & 82.9 & 88.0 & \\
\hline Gas Furnace & AFUE & 73 & 78 & \\
\hline Air Conditioning & SEER & 8.5 & 10.0 & \\
\hline
\end{tabular}

Sources: References 6 and 7. 


\section{3}

\section{METHODOLOGY}

The objective of this analysis is to evaluate the impacts of two building energy standards, ASHRAE 90.2 and the 1989 Model Energy Code, and the standards promulgated under the 1987 National Appliance Energy Efficiency Act (NAECA), on building energy use in new single-family detached housing. The procedure was based on the following steps:

1. We chose 16 base cities for the analysis based on capturing the range of climate variation and population distribution in the U.S.

2. For each of the 16 base cities, we characterized an estimated 1990s average house (conditioned square footage, window area, foundation type, etc.) from available data.

3. We defined the base case condition as the prototype house with current, or 1980s vintage, levels of thermal integrity for the building components and with average 1980s vintage appliance and equipment efficiencies. In other words, the base case represents the average condition for a house built between 1980 and 1989.

4. For each city, we compiled the required wall, ceiling, and floor R-values, foundation insulation, and window glazing levels specified in ASHRAE 90.2P and the 1989 Model Energy Code.

5. We gathered data on 1980s appliance and space-conditioning equipment efficiency and evaluated the impact of the National Appliance Energy Efficiency Act (NAECA) on appliance electricity consumption in the 1990s.

6. We developed procedures for calculating water heating and non-HVAC electric and gas energy use in the prototype buildings. We used the same procedure to calculate the internal gains inputs for DOE-2 to maintain consistency between the estimates of appliance efficiency improvements and changes in internal gains. We use estimates of 1980s average and new 1995 appliance efficiencies as the base case and NAECA code inputs, respectively.

7. We translated the base case, the ASHRAE Standard and the Model Energy Code conservation packages into DOE-2.1D input files and conducted simulations of the base buildings, and the base buildings with combinations of standards packages and appliance and equipment efficiency packages. For the ASHRAE Standard, we simulated buildings in all 16 base cities, while for the Model Energy Code, we simulated only those cities located in states which have adopted the MEC or use it as the primary basis for the state energy code ( 7 total).

8. We summarized the results and developed procedures to calculate electricity and gas cost savings in a few selected climates. 


\section{SELECTION OF BASE CITIES}

The base cities for the analysis were those used in previous GRI residential data base projects. ${ }^{3}$ The cities were chosen to represent the regional variation in the building stock, based on the regional division of the United States given in the Department of Energy's Residential Energy Conservation Survey (RECS) data and GRI regional models. In addition, the cities represent the significant climates types within each region, with the significance determined by population and uniqueness of climate.

To determine the climate centers to use for each region, we relied on earlier work at LBL and $\mathrm{GLOM}^{8}$, a computer-based interactive climate agglomeration program. GLOM is a tool for aggregating Standard Metropolitan Statistical Areas (SMSAs) into climate groups based on climate characteristics and populations. Similarities in heating degree days, cooling degree days, Kt (which measures solar potential), and latent enthalpy hours, allow the clustering of SMSAs to their "closest", or most similar, climate center.

The result was a grouping of sixteen climate zones with 2 in the Northeast, 3 in the North Central, 5 in the South, and 6 in the West. The population centers of these climate groups were used as the weather locations for the simulations. For this study, we used WYEC (Weather Year for Energy Conservation) weather tapes ${ }^{9}$ for all cities except Chicago, New Orleans, and San Francisco. We observed anomalies in the Chicago WYEC weather tape, and WYEC was not available for New Orleans or San Francisco. The base cities are listed in Table 4.

\section{STRUCTURAL ASSUMPTIONS}

We developed an estimated average 1990 vintage prototype building for each base city from published data on building construction trends. Using this basic building form and occupancy characteristics, we varied the thermal integrity values and appliance and equipment efficiencies to model the base case and the various code requirements.

In addition to the generic building characterizations, numerous other assumptions are needed to develop complete models of prototype buildings, and used as input to the DOE-2 simulations. For example, building geometry, average window shading and window operations, and shading from adjacent buildings are not part of any data sets. We relied on our previous study of single-family buildings to develop the necessary DOE-2 inputs for these parameters as well as several others described below. ${ }^{10}$

\section{Building Prototypes}

We used the 1987 NAHB Builder's Survey ${ }^{11}$ and building construction data from U.S. Census Bureau Reports, 1980 to $1989,{ }^{12}$ as the primary data source in developing the building prototype in each location. We also consulted the 1984 RECS data tape ${ }^{13}$ and a previous GRI single-family data base report ${ }^{14}$ for characteristics not available in these other sources. 
Table 4. Base Cities for Building Prototypes and Climates

\begin{tabular}{|c|c|c|c|c|c|c|c|}
\hline \begin{tabular}{|l} 
Census \\
Division
\end{tabular} & $\begin{array}{l}\text { Base } \\
\text { Cities }\end{array}$ & $\begin{array}{l}\text { Weather } \\
\text { Tape }\end{array}$ & $\begin{array}{r}\text { Heat } \\
\text { Degree } \\
\left(60^{\circ} \mathrm{F}\right)\end{array}$ & $\begin{array}{l}\text { ting } \\
\text { e Days } \\
\left(65^{\circ} \mathrm{F}\right)\end{array}$ & \begin{tabular}{|c|} 
Cooling \\
Degree Days \\
$\left(65^{\circ} \mathrm{F}\right)$
\end{tabular} & $\begin{array}{c}\text { Cool. Degree } \\
\text { Hours } / 24 \\
\left(75^{\circ} \mathrm{F}\right)\end{array}$ & $\begin{array}{c}\text { Latent } \\
\text { Enthalpy Days } \dagger \\
\left(75^{\circ} \mathrm{F}, 0.0116 \mathrm{HR}\right)\end{array}$ \\
\hline $\begin{array}{l}\text { NORTHEAST } \\
\text { New England }\end{array}$ & Boston & WYEC & 4396 & 5627 & 699 & 186 & 48 \\
\hline Mid Atlantic & New York & WYEC & 3784 & 4882 & 1005 & 256 & 118 \\
\hline $\begin{array}{l}\text { NORTH CENT } \\
\text { East North } \\
\text { Central }\end{array}$ & Chicago & TMY & 4946 & 6120 & 969 & 318 & 121 \\
\hline $\begin{array}{l}\text { West North } \\
\text { Central }\end{array}$ & $\begin{array}{l}\text { Minneapolis } \\
\text { Kansas City }\end{array}$ & $\begin{array}{l}\text { WYEC } \\
\text { WYEC }\end{array}$ & $\begin{array}{l}6733 \\
3799\end{array}$ & $\begin{array}{l}8004 \\
4799\end{array}$ & $\begin{array}{r}727 \\
1605\end{array}$ & $\begin{array}{l}238 \\
632\end{array}$ & $\begin{array}{r}72 \\
269\end{array}$ \\
\hline $\begin{array}{l}\text { SOUTH } \\
\text { South Atlantic }\end{array}$ & $\begin{array}{l}\text { Washington } \\
\text { Atlanta } \\
\text { Miami }\end{array}$ & $\begin{array}{l}\text { WYEC } \\
\text { WYEC } \\
\text { WYEC }\end{array}$ & $\begin{array}{r}3184 \\
2050 \\
91\end{array}$ & $\begin{array}{r}4180 \\
2965 \\
222\end{array}$ & $\begin{array}{l}1388 \\
1543 \\
3922\end{array}$ & $\begin{array}{r}403 \\
405 \\
1193\end{array}$ & $\begin{array}{r}244 \\
284 \\
1155\end{array}$ \\
\hline $\begin{array}{l}\text { West South } \\
\text { Central }\end{array}$ & $\begin{array}{l}\text { Fort Worth } \\
\text { New Orleans }\end{array}$ & $\begin{array}{l}\text { WYEC } \\
\text { TMY }\end{array}$ & $\begin{array}{r}1571 \\
804\end{array}$ & $\begin{array}{l}2329 \\
1374\end{array}$ & $\begin{array}{l}2495 \\
2503\end{array}$ & $\begin{array}{r}1044 \\
789\end{array}$ & $\begin{array}{l}490 \\
719\end{array}$ \\
\hline $\begin{array}{l}\text { WEST } \\
\text { Mountain }\end{array}$ & $\begin{array}{l}\text { Denver } \\
\text { Albuquerque } \\
\text { Phoenix }\end{array}$ & $\begin{array}{l}\text { WYEC } \\
\text { WYEC } \\
\text { WYEC }\end{array}$ & $\begin{array}{r}4621 \\
3147 \\
675\end{array}$ & $\begin{array}{l}5879 \\
4186 \\
1320\end{array}$ & $\begin{array}{r}611 \\
1256 \\
3609\end{array}$ & $\begin{array}{r}329 \\
540 \\
2144\end{array}$ & $\begin{array}{r}0 \\
9 \\
97\end{array}$ \\
\hline Pacific & $\begin{array}{l}\text { Seattle } \\
\text { San Francisco } \\
\text { Los Angeles }\end{array}$ & $\begin{array}{l}\text { WYEC } \\
\text { oTMY } \\
\text { WYEC }\end{array}$ & \begin{tabular}{|r|}
3583 \\
1682 \\
635
\end{tabular} & $\begin{array}{l}5136 \\
3172 \\
1636\end{array}$ & $\begin{array}{r}90 \\
66 \\
428\end{array}$ & $\begin{array}{l}39 \\
28 \\
54\end{array}$ & $\begin{array}{l}0 \\
0 \\
6\end{array}$ \\
\hline
\end{tabular}

$\dagger$ Latent enthalpy days are in units of (Btu-day/pound of air) and is a measure of the cumulative amount of latent heat removal from the air necessary to reach a base comfort criteria, specified here as $75^{\circ} \mathrm{F}$ and a humidity ratio of 0.0116 .

The survey results were processed statistically and cross-referenced to three major criteria: (1) location (census region, census division, or state) (2) number of stories in the building, and (3) thermal integrity of the building shell. Thus, one building in each of the 16 base cities, which was representative of typical construction types in that location and climate zone, was defined from this analysis. To estimate the characteristics of the average building to be built in the 1990s, we relied primarily on historical data describing 1980 s construction practices, and modified certain characteristics to account for trends identified in the 1980 s data. In general, the average building in the 1990s was assumed to be similar to those built in the 1980 s, only slightly larger. 


\section{Building Size}

The most complete set of data on building size and construction type for the decade of the 1980 s came from U.S. Census Bureau reports. ${ }^{12}$ The Census reports give mean and median square foot data for new construction as well as the total number of units completed annually in each census region. They also tabulate the percentage of new homes in each construction type category: one story, two story, and split-level. From the Census Bureau data we calculated the average square footage for new buildings built between 1980-89 and the proportion of each construction type in each census region. From the NAHB survey data, we calculated the average difference in building size between the different construction types in each census region. For example, the NAHB data showed that 2-story houses were typically larger than 1-story houses by $710 \mathrm{ft}^{2}$ in the Northeast, by $720 \mathrm{ft}^{2}$ in the Midwest, by $560 \mathrm{ft}^{2}$ in the South, and by $400 \mathrm{ft}^{2}$ in the West. Using these data, it was possible to develop a typical 1-story and 2-story building size for each census region. We determined the typical construction type for each state and base city from the NAHB survey data. Using these two data sets, we selected the appropriate building construction type and square footage for the 1980s prototype building in each base city.

In Figure 1, we show the average size of new single family dwellings from several data sources for the period 1980-89. Between 1985 and 1989, average conditioned building area for new single-family dwellings increased at rates between 35 and 70 square feet per year. In addition, Figure 2 shows how construction type also changed through the decade, with the proportion of two-story houses compared to one-story increasing in all parts of the country. Because the trend towards increasing house size seems to be strong and prevalent through all areas of the country, we assumed that house size would continue to increase at approximately the same rate per decade into the 1990s. The most straightforward method for estimating the size of 1990s vintage houses is to add the 1980-89 size increase to the 1980s house size, while accounting for the change in proportion of one and two story houses. Over the decade from 1980 to 1989 , we calculated overall increases in heated floor area 100 to 200 square feet between 1980 and 1989 in each census iagion. We added these increases to average 1980s house size to get average 1990s house size. Based on this method, the prototype house types and sizes are as given in Table 5.

\section{Window Areas}

Data on the amount of window area in new buildings is not readily available. Until 1983, the NAHB Builder Survey compiled data on window area as a percentage of floor area. However, the 1987 Survey only includes "number of windows" without reference to window size. The 1984 RECS data also contains "number of windows" as a data base entry. However, these data sources contain no information about average size of windows. We used the most recent data we identified, from the 1981 NAHB Builder Survey, which provided estimates of windows area as a percentage of floor area. These numbers were developed for a previous GRI 
Figure 1. Average Floor A-ea for New Construction U.S. Single-Family Buildings, 1980-1989

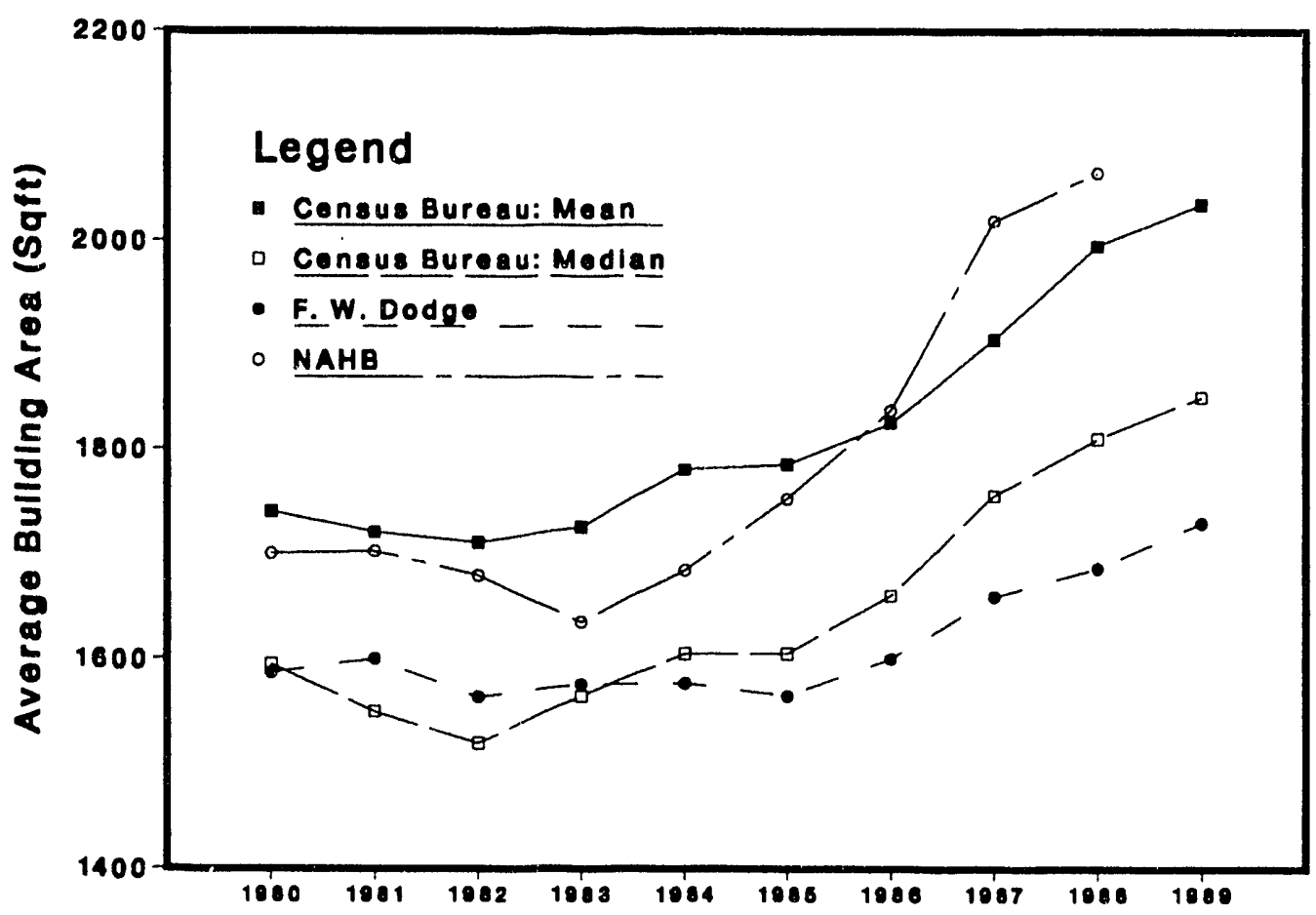

Figure 2. Construction Type for New Construction U.S. Single-Family Bulldings, 1980-1989

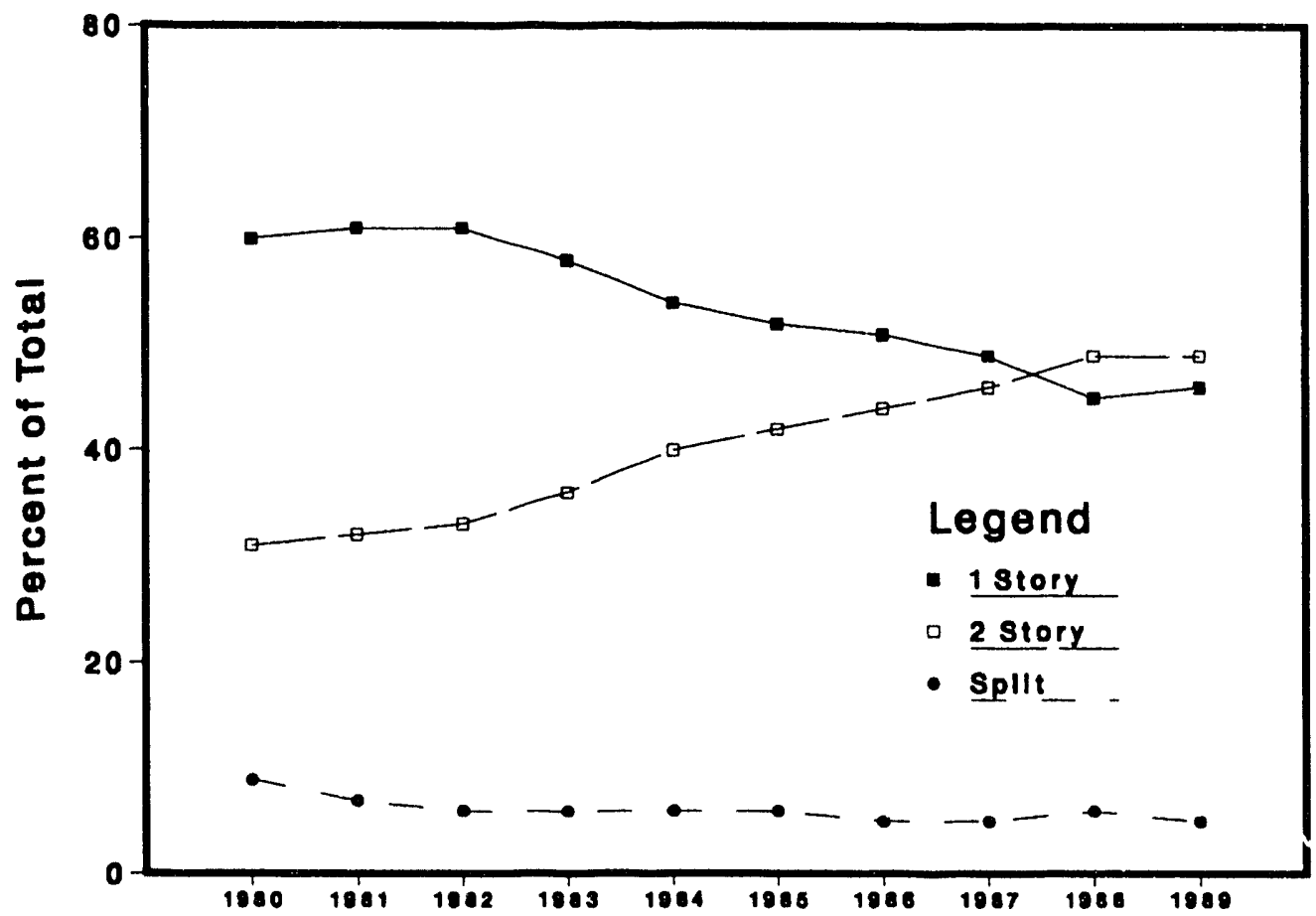


Table 5. General Specifications for Prototype Buildings

\begin{tabular}{|l|c|c|c|c|c|}
\hline $\begin{array}{l}\text { Base } \\
\text { City }\end{array}$ & $\begin{array}{c}\text { Number of } \\
\text { Stories }\end{array}$ & $\begin{array}{c}\text { Heated Floor } \\
\text { Area }\left(\mathbf{f t}^{2}\right)\end{array}$ & $\begin{array}{c}\text { Window Area } \\
\left(\mathrm{ft}^{2}\right)\end{array}$ & $\begin{array}{c}\text { Wall Surface } \\
\text { Type }\end{array}$ & $\begin{array}{c}\text { Foundation } \\
\text { Type }\end{array}$ \\
\hline Boston & 2 & 2280 & 285 & Wood & Basement \\
New York & 2 & 2280 & 265 & Wood & Basement \\
Chicago & 2 & 2420 & 300 & Aluminum & Basement \\
Minneapolis & 2 & 2420 & 264 & Wood & Basement \\
Kansas City & 2 & 2420 & 307 & Wood & Basement \\
Washington & 2 & 2390 & 316 & Aluminum & Basement \\
Atlanta & 2 & 2390 & 289 & Wood & Basement \\
Miami & 1 & 1830 & 242 & Stucco & Slab \\
Fort Worth & 1 & 1830 & 242 & Wood & Slab \\
New Orleans & 1 & 1830 & 242 & Brick & Slab \\
Denver & 2 & 2290 & 291 & Wood & Basement \\
Phoenix & 1 & 1880 & 203 & Stucco & Slab \\
Albuquerque & 1 & 1880 & 203 & Stucco & Slab \\
Seattle & 2 & 2290 & 424 & Wood & Crawl \\
San Francisco & 2 & 2290 & 360 & Stucco & Slab \\
Los Angeles & 2 & 2290 & 360 & Stucco & Slab \\
\hline
\end{tabular}

single-family study. ${ }^{14}$ This same percentage was assumed to apply to houses built in the 1990s.

\section{Wall and Foundation Type}

We used the most predominant wall siding material and foundation type for each base city based on 1986 and 1987 data from the NAHB. ${ }^{15}$ These were assumed to be representative of the 1990s building population as well as the 1980s. They are presented in Table 5 .

\section{Building Thermal Integrity}

For the base case thermal integrity, we used thermal characteristics typical of 1980 s vintage buildings taken as averages from the 1987 NAHB Builder Survey. Because this survey included only one year of data, we checked these results for each base city with the data from the surrounding states, and also with published data summaries from NAHB representing the construction years of 1986 and $1987 .{ }^{15}$

For the upgraded code buildings, we compared the ASHRAE and MEC standards with the base case. In a sense, we "upgraded" the base case building to meet the ASHRAE or MEC standards on a component basis. In cases where the base case met or exceeded the standard, the component thermal integrity remained the same. The insulation specifications for the base case prototype, and the ASHRAE and MEC standards cases, are given in Table 6.

For prototypes with basement foundations, we made assumptions about whether the basement was heated or not, and thus determined the location of the insulation. The base case is 
modeled with the fiedcminant location, and "codes" buildings with floor insulation rather than basement wall insulation. We assume $t$ tat the floor insulation or basement wall insulation requirements provide roughly the same energy performance.

Table 6. Building Envelope Parameters for Base Case and Code Compliance Buildings

\begin{tabular}{|c|c|c|c|c|c|c|c|c|c|c|c|c|c|c|c|}
\hline \multirow[t]{2}{*}{$\begin{array}{l}\text { Base } \\
\text { City } \\
\end{array}$} & \multicolumn{4}{|c|}{\begin{tabular}{|c} 
Base Case \\
Wall Ceil Floor Glzng
\end{tabular}} & $\begin{array}{l}\text { Fndn } \\
\text { s Insul. }\end{array}$ & $\begin{array}{l}\text { Wall } \\
(\mathrm{R})\end{array}$ & $\begin{array}{l}\text { AS } \\
\text { Ceil } \\
\text { (R) }\end{array}$ & $\begin{array}{l}\text { HRA } \\
\text { Fi jor } \\
\text { (R) }\end{array}$ & $\begin{array}{l}\text { A } 90.2 \\
\text { Glzrg } \\
\text { Layers }\end{array}$ & $\begin{array}{l}\text { Fndn } \\
\text { Insul. }\end{array}$ & $\begin{array}{l}\text { Wall } \\
\text { (R) }\end{array}$ & $\begin{array}{r}1 \\
1 \text { Ceil } \\
(\mathrm{R})\end{array}$ & $\begin{array}{c}1989 \\
\text { | Floor } \\
\text { (R) }\end{array}$ & $\begin{array}{l}\text { MEC } \\
\text { r Glzng } \\
\text { Layers }\end{array}$ & $\begin{array}{l}\text { Fndn } \\
\text { Insul. }\end{array}$ \\
\hline & $\overline{13}$ & 27 & 0 & 2 & none & 16 & 28 & 19 & 3 & none & 16 & 37 & 19 & 2 & none \\
\hline New York & 13 & 27 & 19 & 2 & none & 16 & 28 & 19 & 3 & none & & & & & \\
\hline Chicago & 13 & 32 & 0 & 2 & none & 16 & 32 & 19 & 3 & none & & & & & \\
\hline Minneapolis & 19 & 32 & 0 & 2 & $R-54 f t$ & 24 & 48 & 19 & 3 & none & 19 & 40 & 19 & 2 & none \\
\hline Kansas City & 11 & 29 & 0 & 2 & non: & 16 & 29 & 19 & 3 & none & & & & & \\
\hline Washington & 13 & 30 & 19 & 2 & none & 16 & 30 & 19 & 3 & none & & & & & \\
\hline Atlanta & 11 & 27 & 19 & 2 & none & 16 & 28 & 19 & 2 & none & 11 & 27 & 19 & 2 & none \\
\hline Miami & 11 & 25 & 0 & i & none & 16 & 28 & 0 & 1 & $R-52 \mathrm{ft}$ & & & & & \\
\hline Fort Worth & 11 & 27 & 0 & 1 & $\mathrm{R}-52 \mathrm{ft}$ & 16 & 28 & 0 & 1 & $\mathrm{R}-52 \mathrm{ft}$ & 11 & 27 & 0 & 2 & $\mathrm{R}-52 \mathrm{ft}$ \\
\hline New Orleans & 11 & 19 & 0 & 1 & none & 16 & 28 & 0 & 1 & $R-52 \mathrm{ft}$ & & & & & \\
\hline Denver & 13 & 31 & 11 & 2 & none & 16 & 31 & 19 & 3 & none & 13 & 40 & 19 & 2 & none \\
\hline Albuquerque & 13 & 29 & 0 & 2 & $R-52 \mathrm{ft}$ & 16 & 29 & 0 & 3 & $\mathrm{R}-52 \mathrm{ft}$ & 13 & 30 & 0 & 2 & $\mathrm{R}-52 \mathrm{ft}$ \\
\hline Phoenix & 13 & 27 & 0 & 2 & none & 16 & 28 & 0 & 2 & $\mathrm{R}-52 \mathrm{ft}$ & 13 & 27 & 0 & 2 & $\mathrm{R}-\mathrm{S} 2 \mathrm{ft}$ \\
\hline Seattle & 11 & 32 & 19 & 2 & none & 16 & 32 & 19 & 3 & none & & & & & \\
\hline San Francisco & 11 & 25 & 0 & 2 & none & 16 & 28 & 0 & 2 & $\mathrm{R}-52 \mathrm{ft}$ & & & & & \\
\hline Los Angcles & 11 & 25 & 0 & 2 & bone & 16 & 25 & 0 & 2 & none & & & & & \\
\hline
\end{tabular}

Note: Building components are upgraded independently to meet ASHRAE and MEC code provisions.

\section{Building Geometry}

The prototype descriptions specified the numbers of floors, foundation type, and conditioned floor area in each prototype building, but not the architectural layout of the buildings. To transform these general descriptions into DOE-2 input files, we made assumptions about the architecture of typical single-family buildings depending on their climate and building size. The intent was not to create $a$ detailed hypothetical building, but to capture average thermal conditions comrnon to single-family buildings.

In calculating the width and length of the building for foundation heat loss calculations, we used a standard width of $28 \mathrm{feet}$, which is a typical roof truss dimension. This gave some unusually long dimensions for the larger prototypes. While these long dimensions do not represent any actual building, thermally the building can be thought of as pieces arranged in L-shapes or courtyard shapes. The exposed foundation length and wall area are the same for the long building as the contorted building. 
In each prototype, we also modeled an attached, uninsulated two-car garage with a slab floor. The attached wall area was 180 square feet for one story and 240 square feet for two story prototypes, with a garage floor area of 460 square feet.

\section{Infiltration}

The effects of infiltration on building heating and cooling loads were simulated using the Sherman-Grimsrud model. ${ }^{16}$ This is a simplified physical model developed at LBL for air infiltration in residential buildings. The only information needed for the model is the leakage of the building. The leakage quantities, expressed in terms of effective areas, are the total leakage areas of the wall, floor, and ceiling. Weather parameters used in the model include mean wind speed, terrain class, and average temperature difference. The model separates infiltration into two distinct parts: stack and wind-regimes. Each regime is treated separately, with a sharp transition between the two. The model has been tested with data from several sites that differ in climate and construction methods. ${ }^{16}$

We based the assumed effective-leakage-areas for the base case on measured singlefamily results published in the literature and previous studies of single family building simulation. ${ }^{17}$ We assumed the base case prototype would be slightly tighter than earlier-vintage houses, with a fractional leakage area (ELF) of 0.0005. For the ASHRAE and MEC prototypes, we used the climate-specific guidelines in ASHRAE Standard 119 for air leakage to upgrade the base case prototype numbers to meet the ASHRAE standard. ${ }^{18}$ This affected only Boston, New York, Chicago, and Denver $(E L F=0.00046)$ and Minneapolis $(E L F=0.00033)$. Since the net infiltration into a building depends not only on its physical characteristics, but also on the shielding eff $f_{\text {cts }}$ of its surroundings, we simulated the surrounding areas as typical suburban residential r.eighborhoods for all prototypes and in all base cities.

\section{Shading}

The solar gain entering a building depends on the orientation of the windows and walls, the amount of shading due to adjacent buildings, and characteristics and operations of window shades, if available. In this study, we modeled average, rather than typical, building conditions. We created an average building orientation by apportioning the amounts of walls, windows, and doors equally in the four cardinal directions. Similarly, we considered average amounts of shading from two adjacent buildings by modeling semi-transparent shading surfaces with a transmittance of 0.50 with the same height as, and located on all sides of, the prototype building. These building shades were sited 20 feet away for the suburban areas. We accounted for average window shade operations by using a shading coefficient of 0.80 during the winter and 0.60 during the summur. We distinguished between the summer and winter operating modes by adding a special Fortran function into the DOE- 2 input that counted the number of cooling degree-days over the previous four days. 


\section{Foundation Heat Loss}

Since the existing DOE-2 program does not adequately model the building-to-ground interface, we used a Fortran function to incorporate into DOE-2 heat fluxes calculated by a two-dimensional finite difference program developed by the Underground Space Center at the University of Minnesota. We used this program to simulate, on a daily time-step basis, the dynamic behavior of a representative one-foot vertical cross-section of the foundation and surrounding soil extending 50 feet down and 30 feet out from the building.

The finite difference simulations yielded daily fluxes at each node of the finite difference grid for the representative section. We then integrated these fluxes over the "foot-print" of the prototype buildings to produce files of average hourly fluxes through their underground surfaces for each day of the year. During the DOE-2 simulation, these fluxes are read as a function in LOADS, replacing the standard DOE-2 underground flux calculation. A more complete description of this method is given elsewhere. ${ }^{19}$

\section{OPERATING ASSUMPTIONS}

Operating assumptions refer to those actions affecting building energy use that are under the control of the occupants. These include such factors as temperature settings, night thermostat setback, window operations (i.e., opening and closing), and internal loads due to occupants and appliances. For this study, we defined the most average, rather than the optimal, operating conditions in single-family buildings based on survey data and other studies.

\section{Thermostat Settings}

We modeled each of the prototype buildings with the same thermostat settings. The heating set point in the living spaces was held at $70^{\circ} \mathrm{F}$ during the day, with a 8-hour setback to $64^{\circ} \mathrm{F}$ between 11 p.m. and 7 a.m. These assumptions correspond to data from recent RECS surveys that report the mean household temperature in units with heating controls was $69.3^{\circ} \mathrm{F}$; over 64 percent of the respondents turned down their thermostats at night by 3 to 10 degrees. ${ }^{13}$ They also agree with information on thermostat management from other sources. ${ }^{20,21,22}$

To account for natural ventilation, we modeled average window operations by building occupants as follows. During the heating season, window venting (i.e., opening windows) was assumed when indoor temperatures rose above $78^{\circ} \mathrm{F}$, while during the cooling season venting was assumed down to a level of $72^{\circ} \mathrm{F}$ if the following criteria were met: (1) the outdoor temperature was lower than indoor temperatures and not higher than $78^{\circ} \mathrm{F},(2)$ the enthalpy of outdoor air was less than that of indoor air, and (3) the cooling load that hour could be met totally through window venting. Since occupants typically do not adjust windows after going to bed, window conditions were assumed to be fixed between 11 p.m. and 7 a.m. unless indoor temperatures dropped below the heating set point. 


\section{Internal Loads}

Under normal occupancy, a building collects heat, which is termed the internal load, released by people, appliances, and lighting. This internal load reduces a building's heating loads during the winter, but adds to its cooling loads during the summer. After reviewing a previous LBL study of internal loads in single-family residences, ${ }^{10}$ we developed a method for deriving internal loads values for the prototype buildings. We combined assumptions of occupancy levels, schedules, and typical occupancy heat gains; appliance saturations, appliance heat gain schedules, and typical appliance energy use; and annual lighting energy and lighting schedules.

For average occupancy levels, we assumed 3 persons per household in each prototype based on previous LBL studies ${ }^{10}$ and an analysis of the 1984 RECS tape which showed an average of 3.1 occupants per household. We used occupant heat gain of $230 \mathrm{Btu} / \mathrm{hr}$ sensible and $190 \mathrm{Btu} / \mathrm{hr}$ latent per person from ASHRAE. ${ }^{23}$ These values are equivalent to seated, very light work. When combined with the occupant load profile, the total occupant heat gain is $15,200 \mathrm{Btu} /$ day for each prototype ( $8360 \mathrm{Btu} /$ day sensible, $6840 \mathrm{Btu} /$ day latent).

The 1984 RECS data was used to develop average appliance saturations for calculating internal gains. We stratified the RECS single-family data by the nine census divisions, and calculated average appliance saturations in single-family detached dwellings. The RECS data we used did not include clothes washers, so based on clothes dryer saturations between 0.7 and 0.9 we used a saturation of 1.0 for clothes washers. We also assumed a saturation of 1.0 for ovens/ranges. For cooking fuel, RECS data give the saturation of electric and gas cooking. Electric predominates in all census divisions except for the West South Central. RECS also gives separate saturations for electric and gas dryers. In calculating internal gains, we assumed that clothes dryers and cooking were electric. The results also show multiple refrigerators per household. We assumed the primary refrigerator was of new vintage while the fractional number of second refrigerators were assumed to be an older variety. The appliance saturations in each census division are given in Table 7.

We combined these appliance saturations with typical appliance energy use values taken from several sources, including previous LBL work, RECS summaries, the LBL Residential Energy Model, and for the code analysis, LBL-REM estimates of new appliance energy consumption under the requirements of the 1987 National Appliance Energy Conservation Act (NAECA). ${ }^{4,7,10,24}$ For the base case runs, we used energy use values representative of typical 1980s stock appliances. For the NAECA case, we used appliance energy consumption values modified to meet the NAECA code where applicable. All appliance energy use assumptions are

provided in Table 8 . We used annual lighting energy of $1 \mathrm{kWh} / \mathrm{ft}^{2}$, which we have used for previous single-family and multifamily studies.

Not all heat generated by appliances is input to the conditioned space. Therefore, we made assumptions about the average location of appliances and venting of the generated heat. 
Table 7. 1984 RECS Data Tape Results for Single-Family Detached Dwellings Appliance Saturations and Types by Census Division

\begin{tabular}{|l|c|c|c|c|c|c|c|c|c|}
\hline \multicolumn{1}{|c|}{ Appliance } & $\begin{array}{c}\text { New } \\
\text { England }\end{array}$ & $\begin{array}{c}\text { Mid } \\
\text { Atlantic }\end{array}$ & $\begin{array}{c}\text { E. North } \\
\text { Central }\end{array}$ & $\begin{array}{c}\text { W. North } \\
\text { Central }\end{array}$ & $\begin{array}{c}\text { South } \\
\text { Atlantic }\end{array}$ & $\begin{array}{c}\text { E. South } \\
\text { Central }\end{array}$ & $\begin{array}{c}\text { W. South } \\
\text { Central }\end{array}$ & Mountain & Pacific \\
\hline Refrigerator & 1.23 & 1.27 & 1.23 & 1.19 & 1.14 & 1.10 & 1.12 & 1.13 & 1.18 \\
Range/Oven* & 1.00 & 1.00 & 1.00 & 1.00 & 1.00 & 1.00 & 1.00 & 1.00 & 1.00 \\
Dishwasher & .55 & .51 & .34 & .42 & .36 & .41 & .45 & .59 & .46 \\
Clothes Washer* & 1.00 & 1.00 & 1.00 & 1.00 & 1.00 & 1.00 & 1.00 & 1.00 & 1.00 \\
Electric Dryer & .67 & .62 & .49 & .65 & .56 & .71 & .56 & .68 & .54 \\
Gas Dryer & .15 & .24 & .30 & .21 & .12 & .02 & .22 & .12 & .27 \\
FF Freezer & .10 & .15 & .16 & .15 & .17 & .21 & .20 & .19 & .21 \\
Manual Freezer & .27 & .35 & .39 & .46 & .27 & .37 & .37 & .33 & .24 \\
B/W TV & .67 & .61 & .53 & .54 & .60 & .55 & .52 & .49 & .49 \\
Color TV & 1.37 & 1.56 & 1.35 & 1.30 & 1.29 & 1.25 & 1.42 & 1.36 & 1.45 \\
\hline Refr type 1 & FFF & FFF & FFF & FFF & FFF & FFF & FFF & FFF & FFF \\
Refr type 2 & Man & Man & Man & Man & Man & FFF & FFF & Man & Man \\
Cooking Fuel & Elec & Elec & Elec & Elec & Elec & Elec & Gas & Elec & Elec \\
DHW Fuel $\dagger$ & Elec & Elec & Gas & Gas & Elec & Elec & Elec & Gas & Elec/Gas $\ddagger$ \\
\hline
\end{tabular}

FFF $=$ Full Frost Free Freezer Auto $=$ Automatic Defrost Freezer Man $=$ Manual Defrost Freezer

* - Not from RECS data

$\dagger-1987$ RECS data

$\ddagger$ - Electric in North Pacific, Gas in South Pacific

We assumed all of the heat generated by the dishwasher and clothes washer and most of the dryer heat and hot water use would be dissipated outside of the dwelling. We also assumed some of the refrigerators, freezers, and water heaters would, on average, be located in unconditioned spaces. For the DOE-2 simulations, we added this portion of the internal gains to the basement, if existing, or else to the garage. Although there is little data on lighting usage behavior and locations, $10 \%$ of the lighting energy was assigned to lighting outside the conditioned space. We also assigned latent portions to those end uses which generate moisture. These assumptions are included in Table 8. Calculated internal gains values are given in Table 9.

The internal gains profiles we use in the simulations were taken from a California Energy Commission (CEC) study, which provides a daily profile for occupants, appliances, and lighting with seasonal modifications for appliances and lighting. ${ }^{25}$ In total, these profiles are roughly equivalent to those used in the ASHRAE standards methodology. ${ }^{2}$ The average daily profiles are shown in Figure 3. Using the CEC lighting schedule, the peak lighting load is 0.43 Watts $/ \mathrm{ft}^{2}$. The peak appliance loads for the prototypes range from $1.03 \mathrm{~kW}$ for the large prototypes to $0.79 \mathrm{~kW}$ for the average size 1990s prototypes. The effect of the change in appliance energy consumption for NAECA case houses is to decrease internal gains from appliances by 
Table 8. Annual Appliance and Lighting Energy Use

\begin{tabular}{|c|c|c|c|c|c|c|}
\hline & Units & $\begin{array}{l}\text { Base } \\
\text { Case }\end{array}$ & $\begin{array}{c}\text { NAECA } \\
\text { Case }\end{array}$ & $\begin{array}{l}\% \text { to } \\
\text { Cond. }\end{array}$ & $\begin{array}{c}\text { \% to } \\
\text { Uncond. }\end{array}$ & $\begin{array}{c}\% \\
\text { Latent }\end{array}$ \\
\hline \multicolumn{7}{|l|}{ Refrigerators } \\
\hline New & kWh & 1125 & 705 & 100 & 0 & 0 \\
\hline Old & kWh & 1600 & 1600 & 15 & 85 & $\mathbf{0}$ \\
\hline Range/Oven & kWh & 1200 & 1010 & 100 & 0 & 35 \\
\hline Dishwasher & kWh & 200 & 160 & 0 & $\mathbf{0}$ & 0 \\
\hline Clothes; Washer & kWh & 110 & 95 & 0 & 0 & 0 \\
\hline Clothes Dryer & $\mathrm{kWh}$ & 900 & 750 & 10 & 0 & $\mathbf{0}$ \\
\hline Freezer & $k W h$ & 950 & 475 & 50 & 50 & 0 \\
\hline B/W Television & $\mathrm{kWh}$ & 100 & 100 & 100 & 0 & 0 \\
\hline Color Television & $\mathrm{kWh}$ & 320 & 320 & 100 & 0 & 0 \\
\hline Small Appliances & kWh & 300 & 300 & 100 & 0 & 0 \\
\hline \multicolumn{7}{|l|}{ Water Heat } \\
\hline Standby & kWh & 1320 & 1320 & 50 & 50 & 0 \\
\hline Use & $\mathrm{kWh}$ & 2800 & 2800 & 10 & 0 & 33 \\
\hline Lighting & $\mathrm{kWh} / \mathrm{Sqft}$ & 1 & 1 & 90 & 0 & 0 \\
\hline
\end{tabular}

about $17 \%$, with total internal gains decreasing by about $9 \%$.

\section{Non-HVAC Energy Consumption Methodology}

We calculated average annual non-HVAC electricity consumption per building using the same method for calculating internal gains, by combining typical appliance and lighting energy usage with the appliance saturations for each census division derived from the 1984 RECS data tape. Water heating energy was calculated separately. Since electric dryers predominated in all census divisions, we assumed all dryers were electric. The RECS data also show that cooking in new single-family buildings was with electric ranges except for in the West South Central census division. The resulting values are shown in Table 9. The non-HVAC electric and gas values includes all energy used in the household, including that which would occur outside the conditioned space.

\section{Domestic Hot Water Methodology}

Energy use for heating water is a function of several variables such as water storage temperature, inlet and outlet temperatures, air temperatures, and the rate of usage of hot water. In addition, hot water consumption is highly dependent on behavior and is often influenced by cultural and social norms. Obviously, not all of these variables can be incorporated into the estimates of weekly energy consumption for heating water. To calculate the annual hot water load, we used the methodology developed for the California Residential Building Energy Efficiency Standards, ${ }^{26}$ which is mathematically identical to the DOE calculations: ${ }^{27}$ 
Figure 3. Internal Loads Profiles for Prototype Buildings
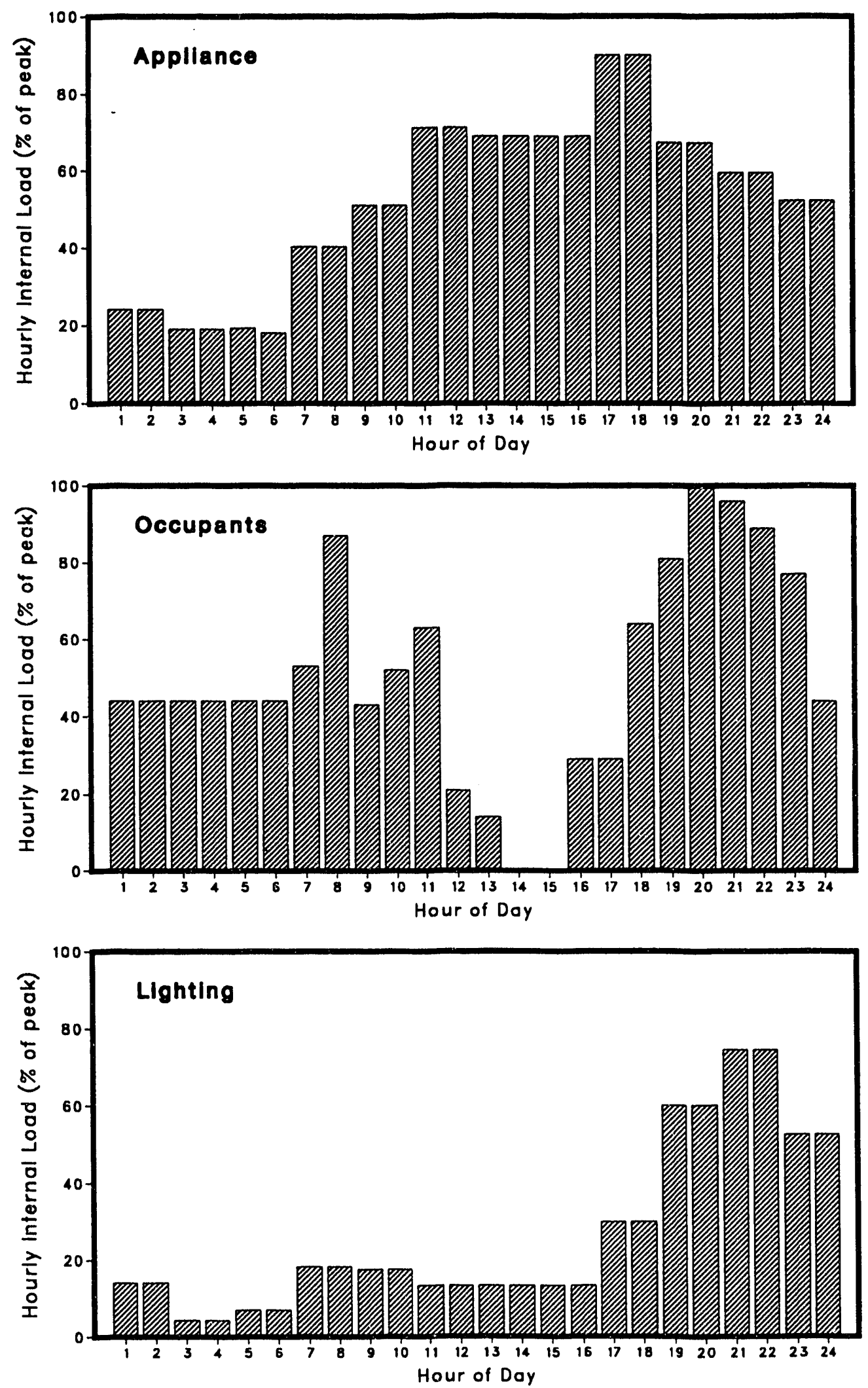
Table 9. Estimated Non-HVAC Electric and Gas Consumption and Internal Loads

\begin{tabular}{|c|c|c|c|c|c|c|c|c|}
\hline & Heated & & Non & HVAC & Applianc & Gains & Total Inten & nal Gains \\
\hline $\begin{array}{l}\text { Base } \\
\text { City }\end{array}$ & $\begin{array}{l}\text { Area } \\
\left(\mathrm{ft}^{2}\right)\end{array}$ & $\begin{array}{l}\text { Appliance } \\
\text { Type }\end{array}$ & $\begin{array}{c}\text { Electric } \\
(\mathrm{kWh} / \mathrm{yr})\end{array}$ & $\begin{array}{c}\text { Gas } \\
\text { (MMBtu/yr) } \\
\end{array}$ & $\begin{array}{c}\text { Sensible } \\
\text { (Btu/day) }\end{array}$ & $\begin{array}{c}\text { Latent } \\
\text { (Btu/day) }\end{array}$ & $\begin{array}{c}\text { Sensible } \\
\text { (Btu/day) }\end{array}$ & $\begin{array}{c}\text { Latent } \\
\text { (Btu/day) }\end{array}$ \\
\hline Boston & 2280 & $\begin{array}{l}\text { Base Case } \\
\text { NAECA Case }\end{array}$ & $\begin{array}{l}7088 \\
6142\end{array}$ & $\begin{array}{l}0.00 \\
0.00\end{array}$ & $\begin{array}{l}36119 \\
30101\end{array}$ & $\begin{array}{l}4791 \\
4169\end{array}$ & $\begin{array}{l}63669 \\
57650\end{array}$ & $\begin{array}{l}11633 \\
11011 \\
\end{array}$ \\
\hline New York & 2280 & $\begin{array}{l}\text { Base Case } \\
\text { NAECA Case } \\
\end{array}$ & $\begin{array}{l}7358 \\
6346 \\
\end{array}$ & $\begin{array}{l}0.00 \\
0.00\end{array}$ & $\begin{array}{l}37333 \\
31019 \\
\end{array}$ & $\begin{array}{l}4791 \\
4169 \\
\end{array}$ & $\begin{array}{l}64883 \\
58569 \\
\end{array}$ & $\begin{array}{l}11633 \\
11011 \\
\end{array}$ \\
\hline Chicago & 2420 & $\begin{array}{l}\text { Base Case } \\
\text { NAECA Case }\end{array}$ & $\begin{array}{l}7310 \\
6291 \\
\end{array}$ & $\begin{array}{l}0.00 \\
0.00\end{array}$ & $\begin{array}{l}36703 \\
30289 \\
\end{array}$ & $\begin{array}{l}4791 \\
4169 \\
\end{array}$ & $\begin{array}{l}65431 \\
59017 \\
\end{array}$ & $\begin{array}{l}11633 \\
11011 \\
\end{array}$ \\
\hline Minneapolis & 2420 & $\begin{array}{l}\text { Base Case } \\
\text { NAECA Case }\end{array}$ & $\begin{array}{l}7366 \\
6306 \\
\end{array}$ & $\begin{array}{l}0.00 \\
0.00\end{array}$ & $\begin{array}{l}36798 \\
30241 \\
\end{array}$ & $\begin{array}{l}4791 \\
4169 \\
\end{array}$ & $\begin{array}{l}65526 \\
58969 \\
\end{array}$ & $\begin{array}{l}11633 \\
11011 \\
\end{array}$ \\
\hline Kansas City & 2420 & $\begin{array}{l}\text { Base Case } \\
\text { NAECA Case } \\
\end{array}$ & $\begin{array}{l}7366 \\
6306 \\
\end{array}$ & $\begin{array}{l}0.00 \\
0.00 \\
\end{array}$ & $\begin{array}{l}36798 \\
30241 \\
\end{array}$ & $\begin{array}{l}4791 \\
4169 \\
\end{array}$ & $\begin{array}{l}65526 \\
58969 \\
\end{array}$ & $\begin{array}{l}1633 \\
11011 \\
\end{array}$ \\
\hline Washington & 2390 & $\begin{array}{l}\text { Base Case } \\
\text { NAECA Case }\end{array}$ & $\begin{array}{l}6924 \\
5973 \\
\end{array}$ & $\begin{array}{l}0.00 \\
0.00 \\
\end{array}$ & $\begin{array}{l}35806 \\
29651 \\
\end{array}$ & $\begin{array}{l}4791 \\
4169 \\
\end{array}$ & $\begin{array}{l}64281 \\
58127 \\
\end{array}$ & $\begin{array}{l}11633 \\
11011 \\
\end{array}$ \\
\hline Atlanta & 2390 & $\begin{array}{l}\text { Base Case } \\
\text { NAECA Case }\end{array}$ & $\begin{array}{l}6924 \\
5973 \\
\end{array}$ & $\begin{array}{l}0.00 \\
0.00\end{array}$ & $\begin{array}{l}35806 \\
29651 \\
\end{array}$ & $\begin{array}{l}4791 \\
4169 \\
\end{array}$ & $\begin{array}{l}64281 \\
58127 \\
\end{array}$ & $\begin{array}{l}11633 \\
11011 \\
\end{array}$ \\
\hline Miami & 1830 & \begin{tabular}{|l} 
Base Case \\
NAECA Case
\end{tabular} & $\begin{array}{l}6364 \\
5413 \\
\end{array}$ & $\begin{array}{l}0.00 \\
0.00\end{array}$ & $\begin{array}{l}35806 \\
29651 \\
\end{array}$ & $\begin{array}{l}4791 \\
4169 \\
\end{array}$ & $\begin{array}{l}59569 \\
53414 \\
\end{array}$ & $\begin{array}{l}11633 \\
11011 \\
\end{array}$ \\
\hline Fort Worth & 1830 & $\begin{array}{l}\text { Base Case } \\
\text { NAECA Case }\end{array}$ & $\begin{array}{l}5397 \\
4556 \\
\end{array}$ & $\begin{array}{l}8.99 \\
4.89 \\
\end{array}$ & $\begin{array}{l}36737 \\
30279 \\
\end{array}$ & $\begin{array}{l}4791 \\
4169 \\
\end{array}$ & $\begin{array}{l}60499 \\
54042 \\
\end{array}$ & $\begin{array}{l}1633 \\
11011 \\
\end{array}$ \\
\hline New Orleans & 1830 & $\begin{array}{l}\text { Base Case } \\
\text { NAECA Case }\end{array}$ & $\begin{array}{l}5397 \\
4556 \\
\end{array}$ & $\begin{array}{l}8.99 \\
4.89 \\
\end{array}$ & $\begin{array}{l}36737 \\
30279 \\
\end{array}$ & $\begin{array}{l}4791 \\
4169 \\
\end{array}$ & $\begin{array}{l}60499 \\
54042\end{array}$ & $\begin{array}{l}11633 \\
11011 \\
\end{array}$ \\
\hline Denver & 2290 & $\begin{array}{l}\text { Base Case } \\
\text { NAECA Case }\end{array}$ & $\begin{array}{l}7049 \\
6034 \\
\end{array}$ & $\begin{array}{l}0.00 \\
0.00 \\
\end{array}$ & $\begin{array}{l}36346 \\
29997 \\
\end{array}$ & $\begin{array}{l}4791 \\
4169 \\
\end{array}$ & $\begin{array}{l}63980 \\
57631 \\
\end{array}$ & $\begin{array}{l}11633 \\
11011 \\
\end{array}$ \\
\hline Albuquerque & 1880 & $\begin{array}{l}\text { Base Case } \\
\text { NAECA Case }\end{array}$ & $\begin{array}{l}6639 \\
5624 \\
\end{array}$ & $\begin{array}{l}0.00 \\
0.00 \\
\end{array}$ & $\begin{array}{l}36346 \\
29997 \\
\end{array}$ & $\begin{array}{l}4791 \\
4169 \\
\end{array}$ & $\begin{array}{l}60530 \\
54181 \\
\end{array}$ & $\begin{array}{l}1633 \\
11011 \\
\end{array}$ \\
\hline Phoenix & 1880 & $\begin{array}{l}\text { Base Case } \\
\text { NAECA Case }\end{array}$ & $\begin{array}{l}6639 \\
5624 \\
\end{array}$ & $\begin{array}{l}0.00 \\
0.00 \\
\end{array}$ & $\begin{array}{l}36346 \\
29997 \\
\end{array}$ & $\begin{array}{l}4791 \\
4169 \\
\end{array}$ & $\begin{array}{l}60530 \\
54181 \\
\end{array}$ & $\begin{array}{l}11633 \\
11011 \\
\end{array}$ \\
\hline Seattle & 2290 & $\begin{array}{l}\text { Base Case } \\
\text { NAECA Case }\end{array}$ & $\begin{array}{l}7074 \\
6096 \\
\end{array}$ & $\begin{array}{l}0.00 \\
0.00\end{array}$ & $\begin{array}{l}36425 \\
30230 \\
\end{array}$ & $\begin{array}{l}4791 \\
4169 \\
\end{array}$ & $\begin{array}{l}64059 \\
57864 \\
\end{array}$ & $\begin{array}{l}11633 \\
11011 \\
\end{array}$ \\
\hline San Francisco & 2290 & $\begin{array}{l}\text { Base Case } \\
\text { NAECA Case }\end{array}$ & $\begin{array}{l}7074 \\
6096 \\
\end{array}$ & $\begin{array}{l}0.00 \\
0.00 \\
\end{array}$ & $\begin{array}{l}36425 \\
30230 \\
\end{array}$ & $\begin{array}{l}4791 \\
4169 \\
\end{array}$ & $\begin{array}{l}64059 \\
57864 \\
\end{array}$ & $\begin{array}{l}11633 \\
11011 \\
\end{array}$ \\
\hline Los Angeles & 2290 & $\begin{array}{l}\text { Base Case } \\
\text { NAECA Case }\end{array}$ & $\begin{array}{l}7074 \\
6096 \\
\end{array}$ & $\begin{array}{l}0.00 \\
0.00\end{array}$ & $\begin{array}{l}36425 \\
30230\end{array}$ & $\begin{array}{l}4791 \\
4169 \\
\end{array}$ & $\begin{array}{l}64059 \\
57864 \\
\end{array}$ & $\begin{array}{l}1633 \\
11011 \\
\end{array}$ \\
\hline
\end{tabular}

Note: Total Internal Gains = Appliance + Lighting + Occupants

Occupant Gains $=8360 \mathrm{Btu} /$ day sensible and $6840 \mathrm{Btu} /$ day latent

Lighting Gains $=8.42 \mathrm{Btu} /$ day- $\mathrm{ft}^{2}$ sensible $*$ heated area $\left(\mathrm{ft}^{2}\right)$

Non-HVAC energy consumption in Table 9 does not include hot water energy consumption.

One of the most uncertain parameters in the estimation of hot water loads in any building type is the average per capita water usage. For example, average measured water consumption reported in the literature varies between types of dwellings (single-family, multifamily, etc.), geographic regions, and time of year. Standard values include the DOE standard assumption for single-family residences, which is about $21.4 \mathrm{gal} /$ person-day ( $64.2 \mathrm{gal} /$ household-day) and assumes the presence of a clothes washer in each residence, and the ASHRAE standard value 


$$
\text { Load }=W \times C_{p} \times\left(T_{T}-T_{M}\right) \times 365 \text { days }
$$

where $W=$ average daily hot water consumption ( 62.4 gallons) ${ }^{28}$

(based on 3 occupants)

$\mathrm{C}_{\mathrm{p}}=$ energy required per gallon heated $\left(8.25 \mathrm{Btu} / \mathrm{gal} /{ }^{\circ} \mathrm{F}\right)$

$\mathrm{T}_{\mathrm{T}}=\quad$ tank set temperature $\left(140^{\circ} \mathrm{F}\right)$

$\mathrm{T}_{\mathrm{M}}=\quad$ city water main temperature (estimated by well temperatures)

of $62.4 \mathrm{gal} /$ household-day. ${ }^{28} \mathrm{~A}$ recent survey for ASHRAE of available field-measured hot water usage data showed the ASHRAE standard assumption to be valid as an average national value. $^{29}$ This survey also showed substantial variation between climatic locations and between seasons in each location. Thus, we also added a seasonal variation in consumption levels as a function of outdoor temperatures based on methods described in a previous study for multifamily buildings. ${ }^{30}$

The estimated domestic hot water load reflects only the amount of heat necessary to raise the temperature of the water from the main to the tank temperature of $140 \mathrm{~F}$. The effects of burner efficiency and standby losses are not considered in the calculation of water heating loads, but standby losses are included in the internal loads assumptions (see Table 8).

Since the average well temperature in most cities corresponds to the average air temperature, we use data from the weather tapes to estimate city water main temperature $\left(T_{M}\right)$. Table 10 shows the average air and well temperatures for the base cities in this analysis.

Table 10. Average Air and Well Temperature for Base Cities

\begin{tabular}{|lcc|lcc|}
\hline & $\begin{array}{c}\text { Annual Average } \\
\text { Air Temp. } \\
\text { City }\end{array}$ & $\begin{array}{c}\text { Well } \\
\text { Temp. } \\
\text { (F) }\end{array}$ & \multicolumn{1}{|c}{ City } & $\begin{array}{c}\text { Annual Average } \\
\text { Air Temp. } \\
\text { (F) }\end{array}$ & $\begin{array}{c}\text { Well } \\
\text { Temp. } \\
\text { (F) }\end{array}$ \\
\hline Albuquerque & 56.6 & 62.0 & Los Angeles & 61.0 & 62.0 \\
Atlanta & 60.6 & 64.0 & Miami & 75.2 & 77.0 \\
Boston & 51.0 & 48.0 & Minneapolis & 45.1 & 45.0 \\
Chicago & 50.7 & 51.0 & New Orleans & 68.0 & 70.0 \\
Denver & 50.1 & 47.0 & Phoenix & 71.5 & 66.0 \\
Fort Worth & 65.1 & 68.0 & San Francisco & 55.4 & 58.0 \\
New York & 54.2 & 52.0 & Seattle & 50.5 & 52.0 \\
Kansas City & 67.6 & 68.0 & Washington & 57.1 & 54.0 \\
\hline
\end{tabular}

To determine annual water heating energy, we applied the energy factor (EF, which is the estimated seasonal efficiency) determined from the DOE test procedure to the annual hot water loads calculated as shown above, for the water heating fuel which predominated in the census division where the cities are located. The energy factor is derived from a simulated usage test 
under laboratory conditions, and is a reliable estimate of seasonal efficiency as long as the operating conditions of the water heater are similar to those of the DOE test procedure. For the base case, we used an energy factor of $\mathbf{5 1 . 2}$ for gas water heaters and $\mathbf{8 2 . 9}$ for electric water heaters, which are typical of 1980 s vintage water heaters. For new water heaters under the NAECA standards, we use energy factors of 56.1 for gas and 88.0 for electric, both of which were taken from the LBL Residential Energy Model forecasts. ${ }^{7}$

\section{HVAC Energy Use Calculation}

We simulated HVAC energy use with typical gas furnace and central electric air conditioning systems. For one story buildings, the systems included a $50,000 \mathrm{Btu} / \mathrm{hr}$ furnace, a $36,000 \mathrm{Btu} / \mathrm{hr}$ air-conditioner, with a system air flow rate of $1050 \mathrm{cfm}$. For two story buildings, the systems included a $100,000 \mathrm{Btu} / \mathrm{hr}$ furnace, a $48,000 \mathrm{Btu} / \mathrm{hr}$ air-conditioner, and a system air flow rate of $2100 \mathrm{cfm}$.

We simulated two HVAC equipment efficiencies, one for 1980s vintage equipment and one with equipment meeting the NAECA requirements. The assumed efficiencies are given in Table 11. 1980 stock efficiencies are weighted averages for 1981-89 shipments taken from the LBL-REM data base. NAECA requirements are those listed in the code. The NAECA furnace standard of AFUE $=78 \%$ was increased to $80 \%$ following the assumption that $2 \%$ of the jacket loss would be input to the heated space (the new AFUE test calculation assumes the jacket loss goes to the unheated space). The increase in either AFUE or SEER for space-conditioning equipment is assumed to represent an equivalent proportional increase in the steady-state efficiency. We did not assume different part loads efficiency curves or other performance parameter curves between the base case and the standards-level equipment.

Table 11. HVAC Equipment Efficiency Assumptions

\begin{tabular}{|lccc|}
\hline Equipment & Unit & 1980s Average & NAECA Requirement \\
\hline Furnace & AFUE & 73.0 & $80.0 *$ \\
Air Conditioner & SEER & 8.5 & 10.0 \\
\hline
\end{tabular}

* Code value is $78.0 \% .2 \%$ jacket loss added to heated space.

\section{METHODS FOR CALCULATING ENERGY COST SAVINGS}

For illustrative purposes, utility costs were calculated for a few base cities to provide some estimate of the potential dollar savings resulting from the various thermal or appliance codes. Four cities that represent high heating or high cooling energy use were chosen for this 
exercise. The cities include Chicago and Minneapolis for gas (heating), and Atlanta and Washington for electricity (cooling). The utility costs were taken from a 1990 study sponsored by the Gas Research Institute. ${ }^{31}$ The data in these volumes represent rates that were in effect on January 1, 1990.

Although the GRI data include a wide variety of innovative rate structures (time-of-use, load factors, block pricing, etc.), we used the basic residential rate schedule in all cases. For gas consumption (space heating and water heating), the winter rates were used if the winter and summer schedules were different. This method may have slightly overestimated the domestic hot water heating energy costs during the summer months. For electricity use (cooling and non-HVAC electricity such as lighting and appliances), the calculation methods were somewhat more complex. In estimating the electricity rates, costs for cooling energy use were calculated separately from those for non-HVAC consumption. The summer rates were used for the cooling costs, while an average of summer and winter rates were assumed in the calculation of the non-HVAC costs. This method may underestimate any air-conditioning costs which may occur in the non-summer months.

The annual general service rates were calculated in a similar manner for gas and electricity usage except for the caveats described above. An example of the calculation procedure used to estimate the costs of gas usage in Minneapolis and electricity usage in Atlanta is shown in Table 12. This procedure considers several factors in addition to the energy charge. For example, there is usually a monthly customer charge (used as annual totals in our calculation), an energy cost adjustment or fuel cost factor charged for energy usage, taxes, and a surcharge (i.e., charge levied by utilities to recover fees or other imposts other than taxes). In some cases, the energy charge is defined by energy blocks with differing rates and/or by seasonal rates. 


\begin{tabular}{|c|c|c|}
\hline \multicolumn{3}{|c|}{$\begin{array}{l}\text { Table 12a. Calculation of Natural Gas Energy Costs } \\
\text { Gas Heating in a Minneapolis House Meeting ASHRAE } 90.2\end{array}$} \\
\hline \multicolumn{3}{|c|}{ Annual Energy Usage - 103.8 MMBtu } \\
\hline 1. & Annual Customer/Minimum Charge: & $\$ 36.00$ \\
\hline \multirow[t]{3}{*}{2.} & Energy Charge: & $\$ 500.32$ \\
\hline & Block $1-0.3 \mathrm{MMBtu}$ x 0.00 (free) & \\
\hline & Block 2- 103.5 MMBtu x 4.8384 & \\
\hline \multirow[t]{2}{*}{3.} & Energy Cost Adjustment: & $\$ 10.85$ \\
\hline & 103.8 MMBtu x .1045 & \\
\hline \multirow[t]{2}{*}{4.} & Tax Adjustment: & None \\
\hline & Exempt November - April & \\
\hline \multirow[t]{2}{*}{5.} & Surcharge: & $\$ 16.09$ \\
\hline & $3.0 \% \times(1+2)$ & \\
\hline 6. & Total Annual Charge: & $\$ 563.26$ \\
\hline
\end{tabular}

\begin{tabular}{|llr|}
\hline \multicolumn{3}{|c|}{ Table 12b. Calculation of Electric Energy Costs } \\
Electricity Use in Atlanta House Meeting NAECA Code
\end{tabular}




\section{4 \\ RESULTS AND DISCUSSION}

In this chapter, we discuss the effects of two building energy standards, ASHRAE 90.2P and the Model Energy Code, and the National Appliance Energy Conservation Act (NAECA) and Amendments on energy use in new single-family buildings. First, we present the results for space heating energy consumption and other non-HVAC uses of natural gas. For space heating, the thermal codes are found to be more effective in reducing energy use than the improved appliance and equipment efficiencies. In addition, the effects of the NAECA on water heating energy use and cooking energy consumption are compared between regions and prototypes. Second, we present the results for standards impacts on electricity consumption, including cooling and non-HVAC electricity end uses. The provisions of the NAECA -- both appliance and equipment efficiency improvements -- are found to be more effective in reducing total cooling energy use than either the proposed ASHRAE Standard or Model Energy Code. To gain a better understanding of the causative factors, we discuss the effects of space conditioning and non-space conditioning separately. We also consider the effects of the standards for typical household appliances and HVAC equipment both separately and in combination. We also present the impacts of the combined effects of the thermal codes and the full provisions of the NAECA on heating and cooling energy use.

Third, we look in some detail at the interactions between changes in internal gains due to the NAECA appliance standards and space conditioning loads and energy usage. These results show the magnitude of the potential gains or losses in heating and cooling from appliance standards in new buildings. Fourth, we present the total energy savings for each building prototype from selected standards combinations. The results here show the relative magnitudes of standards impacts on total natural gas and electricity usage for the prototype buildings.

For this analysis, we chose specific technologies to analyze in terms of energy savings; that is, all houses have heating with gas furnaces and central electric air-conditioning equipment. We also tabulate the results for appliance energy use based on data which shows the predominant fuel used for water heating and cooking. However, in Table 13, we show the water heating energy use for each base city for both gas and electric water heaters, both under the Base Case condition and under the NAECA standard for water heaters. We provide both gas and electric energy use for each city even though the most dominant water heater is selected for the analysis described below. The dominant type represents the most prevalent type in each Census Division reported in the 1987 RECS data tape and shown in Table 7.

In Table 14, we show the simulated energy consumption and peak HVAC energy use for each of the prototype buildings in the base case and under each of the standard combinations. The cities are listed by census division. The results show the impact on end use energy consumption from the NAECA appliance standards, the NAECA equipment standards, the entire 
Table 13. Annual Hot Water Use and Water Heat Energy by Fuel and Location

\begin{tabular}{|l|cc|cc|cc|}
\hline & $\begin{array}{l}\text { Annual Average } \\
\text { Hot Water Use }\end{array}$ & $\begin{array}{c}\text { Annual } \\
\text { Load }\end{array}$ & \multicolumn{2}{|c|}{$\begin{array}{c}\text { DHW Gas Use } \\
\text { (MMBtu/yr) }\end{array}$} & \multicolumn{2}{|c|}{$\begin{array}{c}\text { DHW Electricity Use } \\
\text { (kWh/yr) }\end{array}$} \\
& (Gal/Day) & (MMBtu/yr) & Old & New & Old & New \\
\hline Boston & 64.3 & 17.81 & 34.78 & 31.73 & 6297 & 5929 \\
New York & 62.8 & 16.63 & 32.49 & 29.64 & 5882 & 5539 \\
Chicago & 64.4 & 17.27 & 33.72 & 30.76 & 6105 & 5749 \\
Minneapolis & 67.1 & 19.18 & 37.47 & 34.18 & 6783 & 6387 \\
Kansas City & 61.9 & 16.03 & 31.30 & 28.55 & 5666 & 5336 \\
Washington & 61.4 & 15.90 & 31.06 & 28.33 & 5623 & 5295 \\
Atlanta & 59.8 & 13.68 & 26.71 & 24.37 & 4836 & 4554 \\
Miami & 52.9 & 10.03 & 19.60 & 17.87 & 3547 & 3340 \\
Fort Worth & 57.6 & 12.50 & 24.41 & 22.27 & 4419 & 4161 \\
New Orleans & 56.3 & 11.86 & 23.17 & 21.13 & 4194 & 3950 \\
Denver & 64.7 & 18.12 & 35.39 & 32.28 & 6407 & 6033 \\
Albuquerque & 61.6 & 14.48 & 28.28 & 25.80 & 5119 & 4821 \\
Phoenix & 54.6 & 12.17 & 23.78 & 21.69 & 4304 & 4053 \\
Seattle & 64.5 & 17.10 & 33.39 & 30.46 & 6045 & 5692 \\
San Francisco & 62.2 & 15.36 & 30.00 & 27.37 & 5431 & 5115 \\
Los Angeles & 59.6 & 13.99 & 27.33 & 24.93 & 4947 & 4659 \\
\hline
\end{tabular}

Gas: $\quad$ Old Energy Factor $=0.5120$, New Energy Factor $=0.5613$

Electric: $\quad$ Old Energy Factor $=0.8287$, New Energy Factor $=0.88$

NAECA standard set, each of the envelope standards, and the combined envelope and NAECA standards. The numbers in the table are discussed in the following sections. In Appendix A, we also present the heating and cooling loads for each of these standard conditions; that is, the heating and cooling requirements without considering the equipment efficiencies.

\section{STANDARDS IMPACTS ON NATURAL GAS CONSUMPTION}

In this section we describe the impact of the standards on annual natural gas consumption and peak natural gas usage for space heating. We consider two major end uses; space heating and non-HVAC gas, which includes water heating and cooking.

\section{Effects on Gas Space Heating Consumption}

For most locations, the space heating energy consumption in the the single-family prototypical houses is significantly reduced by the thermal envelope requirements found in MEC and ASHRAE. The level of energy savings is greater for the ASHRAE standard than for the MEC, and is generally greater in colder climates, both on an absolute and percentage basis. In Figure 4, the thermal code cases are compared to the base case condition for gas space heating. As shown in Table 14, the ASHRAE 90 Standard is more effective in reducing heating energy 
Table 14. End Use Eaergy Consumption Under Efficiency Standard Combinations

\begin{tabular}{|c|c|c|c|c|c|c|c|c|}
\hline \multirow{2}{*}{$\begin{array}{l}\text { City and } \\
\text { Standards Case }\end{array}$} & \multicolumn{3}{|c|}{$\begin{array}{c}\text { Natural Gas } \\
\text { Consumption (MMBtu/yr) }\end{array}$} & \multicolumn{3}{|c|}{$\begin{array}{c}\text { Electricity } \\
\text { Consumption }(\mathrm{kWh} / \mathrm{yr})\end{array}$} & \multirow{2}{*}{$\begin{array}{c}\text { Peak } \\
\text { Heat } \\
(\mathrm{kBtu} / \mathrm{hr})\end{array}$} & \multirow{2}{*}{$\begin{array}{l}\text { Peak } \\
\text { Cool } \\
(\mathrm{kW})\end{array}$} \\
\hline & Heat & Appliance & Total & Cool & Appliancet & Total & & \\
\hline \multicolumn{9}{|l|}{ Boston } \\
\hline Base Case & 95.9 & 0.0 & 95.9 & 1481 & 13385 & 14866 & 61.6 & 3.4 \\
\hline NAECA Appliance & 97.8 & 0.0 & 97.8 & 1450 & $120 \% 1$ & 13521 & 61.6 & 3.3 \\
\hline NAECA Equipment & 87.5 & 0.0 & 87.5 & 1335 & 13385 & 14720 & 56.2 & 2.9 \\
\hline NAECA Combination & 89.2 & 0.0 & 89.2 & 1310 & 12071 & 13381 & 56.2 & 2.8 \\
\hline ASHRAE & 69.9 & 0.0 & 69.9 & 1558 & 13385 & 14943 & 55.7 & 3.3 \\
\hline ASHRAE + NAECA & 65.3 & 0.0 & 65.3 & 1364 & 12071 & 13435 & 50.1 & 2.7 \\
\hline MEC & 78.2 & 0.0 & 78.2 & 1624 & 13385 & 15009 & 59.4 & 3.4 \\
\hline MEC + NAECA & 72.8 & 0.0 & 72.8 & 1416 & 12071 & 13487 & 53.5 & 2.9 \\
\hline \multicolumn{9}{|l|}{ New York } \\
\hline Base Case & 68.8 & 0.0 & 68.8 & 1724 & 13240 & 14964 & 49.8 & 2.6 \\
\hline NAECA Appliance & 70.5 & 0.0 & 70.5 & 1668 & 11885 & 13553 & 49.1 & 2.5 \\
\hline NAECA Equipment & 62.8 & 0.0 & 62.8 & 1533 & 13240 & 14773 & 45.5 & 2.2 \\
\hline NAECA Combination & 64.3 & 0.0 & 64.3 & 1485 & 11885 & 13370 & 44.8 & 2.2 \\
\hline ASHRAE & 57.5 & 0.0 & 57.5 & 1653 & 13240 & 14893 & 46.2 & 2.4 \\
\hline ASHRAE + NAECA & 53.9 & 0.0 & 53.9 & 1413 & 11885 & 13298 & 40.8 & 2.0 \\
\hline \multicolumn{9}{|l|}{ Chicago } \\
\hline Base Case & 103.9 & 33.7 & 137.6 & 1999 & 7310 & 9309 & 67.2 & 3.4 \\
\hline NAECA Appliance & 105.9 & 30.8 & 136.6 & 1949 & 6291 & 8240 & 67.9 & 3.4 \\
\hline NAECA Equipment & 94.8 & 33.7 & 128.5 & 1776 & $731 r$ & 9086 & 61.3 & 2.9 \\
\hline NAECA Combination & 96.6 & 30.8 & 127.4 & 1734 & 6291 & 8025 & 61.9 & 2.9 \\
\hline ASHRAE & 76.5 & 33.7 & 110.2 & 2137 & 7310 & 9447 & 59.1 & 3.3 \\
\hline ASHRAE + NAECA & 71.3 & 30.8 & 102.1 & 1842 & 6291 & 8133 & 53.9 & 2.8 \\
\hline \multicolumn{9}{|l|}{ Minneapolis } \\
\hline Base Case & 107.5 & 37.5 & 144.9 & 1473 & 7366 & 8839 & 56.4 & 2.7 \\
\hline NAECA Appliance & 109.6 & 34.2 & 143.7 & 1425 & 6306 & 7731 & 56.4 & 2.6 \\
\hline NAFCA Equipment & 98.1 & 37.5 & 135.5 & 1331 & 7366 & 8697 & 51.5 & 2.3 \\
\hline NAECA Combination & 100.0 & 34.2 & 134.1 & 1291 & 6306 & 7597 & 51.5 & 2.3 \\
\hline ASHRAE & 69.6 & 37.5 & 107.0 & 1639 & 7366 & 9005 & 47.6 & 2.8 \\
\hline ASHRAE + NAECA & 65.2 & 34.2 & 99.3 & 1409 & 6306 & 7715 & 42.8 & 2.4 \\
\hline MEC & 89.1 & 37.5 & 126.6 & 1759 & 7366 & 9125 & 54.2 & 3.1 \\
\hline MEC + NAECA & 83.1 & 34.2 & 117.3 & 1527 & 6306 & 7833 & 49.5 & 2.6 \\
\hline \multicolumn{9}{|l|}{ Kansas City } \\
\hline Base Case & 71.9 & 31.3 & 103.2 & 3131 & 7366 & 10497 & 57.3 & 3.4 \\
\hline NAECA Appliance & 73.5 & 28.5 & 102.0 & 3041 & 6306 & 9347 & 56.6 & 3.3 \\
\hline NAECA Equipment & 65.6 & 31.3 & 96.9 & 2730 & 7366 & 10096 & 52.3 & 2.9 \\
\hline NAECA Combination & 67.1 & 28.5 & 95.6 & 2654 & 6306 & 8960 & 51.6 & 2.8 \\
\hline ASHRAE & 49.0 & 31.3 & 80.3 & 3327 & 7366 & 10693 & 53.6 & 3.2 \\
\hline ASHRAE + NAECA & 45.9 & 28.5 & 74.5 & 2799 & 6305 & 9105 & 47.6 & 2.7 \\
\hline \multicolumn{9}{|l|}{ Washington } \\
\hline Base Case & 62.6 & 0.0 & 62.6 & 2627 & 12547 & 15174 & 60.8 & 3.1 \\
\hline NAECA Appliance & 64.0 & 0.0 & 64.0 & 2543 & 11268 & 13811 & 59.3 & 3.0 \\
\hline NACCA Equipment & 57.1 & 0.0 & 57.1 & 2299 & 12547 & 14846 & 55.5 & 2.7 \\
\hline NAECA Combination & 58.4 & 0.0 & 58.4 & 2228 & 11268 & 13496 & 54.2 & 2.6 \\
\hline ASHRAE & 51.3 & 0.0 & 51.3 & 2508 & 12547 & 15055 & 56.4 & 2.9 \\
\hline ASHRAE + NAECA & 48.1 & 0.0 & 48.1 & 2132 & 11268 & 13400 & 50.8 & 2.4 \\
\hline
\end{tabular}

† Appliance $i n e r g y$ includes domestic water heating and cooking of appropriate fuel for each location. 
Table 14. End Use Energy Consumption Under Efficiency Standard Combinations

\begin{tabular}{|c|c|c|c|c|c|c|c|c|}
\hline \multirow{2}{*}{$\begin{array}{l}\text { City and } \\
\text { Standards Case }\end{array}$} & \multicolumn{3}{|c|}{$\begin{array}{c}\text { Natural Gas } \\
\text { Consumption (MMBtu/yr) }\end{array}$} & \multicolumn{3}{|c|}{$\begin{array}{c}\text { Electricity } \\
\text { Consumption }(\mathrm{kWh} / \mathrm{yr})\end{array}$} & \multirow{2}{*}{$\begin{array}{c}\text { Peak } \\
\text { Heat } \\
(\mathrm{kBtu} / \mathrm{hr}) \\
\end{array}$} & \multirow{2}{*}{$\begin{array}{l}\text { Peak } \\
\text { Cool } \\
\text { (kW) }\end{array}$} \\
\hline & Heat & Appliance $\dagger$ & Total & Cool & Appliance $\dagger$ & Total & & \\
\hline \multicolumn{9}{|l|}{ Atlanta } \\
\hline Base Case & 38.2 & 0.0 & 38.2 & 2716 & 11760 & 14476 & 52.2 & 2.7 \\
\hline NAECA Appliance & 39.3 & 0.0 & 39.3 & 2613 & 10527 & 13140 & 51.4 & 2.7 \\
\hline NAECA Equipment & 34.9 & 0.0 & 34.9 & 2366 & 11760 & 14126 & 47.6 & 2.3 \\
\hline NAECA Combination & 35.8 & 0.0 & 35.8 & 2277 & 10527 & 12804 & 46.9 & 2.3 \\
\hline ASHRAE & 33.5 & 0.0 & 33.5 & 2678 & 11760 & 14438 & 51.4 & 2.7 \\
\hline ASHRAE + NAECA & 31.4 & 0.0 & 31.4 & 2240 & 10527 & 12767 & 45.6 & 2.2 \\
\hline MEC & 38.2 & 0.0 & 38.2 & 2716 & 11760 & 14476 & 52.2 & 2.7 \\
\hline MEC + NAECA & 35.8 & 0.0 & 35.8 & 2277 & 10527 & 12804 & 46.9 & 2.3 \\
\hline \multicolumn{9}{|l|}{ Miami } \\
\hline Base Case & 2.9 & 0.0 & 2.9 & 5203 & 9911 & 15114 & 31.2 & 2.4 \\
\hline NAECA Appliance & 3.0 & 0.0 & 3.0 & 4971 & 8753 & 13724 & 31.3 & 2.3 \\
\hline NAECA Equipment & 2.7 & 0.0 & 2.7 & 4450 & 9911 & 14361 & 28.4 & 2.0 \\
\hline NAECA Combination & 2.8 & 0.0 & 2.8 & 4252 & 8753 & 13005 & 28.5 & 2.0 \\
\hline ASHRAE & 2.4 & 0.0 & 2.4 & 5113 & 9911 & 15024 & 29.3 & 2.3 \\
\hline ASHRAE + NAECA & 2.3 & 0.0 & 2.3 & 4171 & 8753 & 12924 & 26.8 & 1.9 \\
\hline \multicolumn{9}{|l|}{ Fort Worth } \\
\hline Base Case & 38.5 & 9.0 & 47.5 & 3589 & 9816 & 13405 & 44.8 & 3.2 \\
\hline NAECA Appliance & 39.7 & 4.9 & 44.6 & 3463 & 8717 & 12180 & 44.9 & 3.2 \\
\hline NAECA Equipment & 35.2 & 9.0 & 44.2 & 3104 & 9816 & 12920 & 40.9 & 2.8 \\
\hline NAECA Combination & 36.2 & 4.9 & 41.1 & 2997 & 8717 & 11714 & 41.0 & 2.7 \\
\hline ASHRAE & 36.0 & 9.0 & 45.0 & 3517 & 9816 & 13333 & 43.2 & 3.2 \\
\hline ASHRAE + NAECA & 33.9 & 4.9 & 38.8 & 2932 & 8717 & 11649 & 39.5 & 2.7 \\
\hline MEC & 26.5 & 9.0 & 35.4 & 3341 & 9816 & 13157 & 36.7 & 2.9 \\
\hline MEC + NAECA & 25.1 & 4.9 & 30.0 & 2778 & 8717 & 11495 & 33.6 & 2.4 \\
\hline \multicolumn{9}{|l|}{ New Orleans } \\
\hline Base Case & 21.5 & 9.0 & 30.5 & 2976 & 9591 & 12567 & 40.3 & 2.5 \\
\hline NAECA Appliance & 22.4 & 4.9 & 27.3 & 2840 & 8506 & 11346 & 39.6 & 2.5 \\
\hline NAECA Equipment & 19.6 & 9.0 & 28.6 & 2571 & 9591 & 12162 & 36.8 & 2.1 \\
\hline NAECA Combination & 20.4 & 4.9 & 25.3 & 2455 & 8506 & 10961 & 36.1 & 2.1 \\
\hline ASHRAE & 18.8 & 9.0 & 27.8 & 2833 & 9591 & 12424 & 38.8 & 2.4 \\
\hline ASHRAE + NAECA & 17.9 & 4.9 & 22.8 & 2332 & 8506 & 10838 & 34.8 & 2.0 \\
\hline \multicolumn{9}{|l|}{ Denver } \\
\hline Base Case & 62.7 & 35.4 & 98.0 & 1605 & 7049 & 8654 & 57.8 & 2.6 \\
\hline NAECA Appliance & 64.2 & 32.3 & 96.5 & 1561 & 6034 & 7595 & 57.0 & 2.5 \\
\hline NAECA Equipment & 57.2 & 35.4 & 92.6 & 1434 & 7049 & 8483 & 52.7 & 2.2 \\
\hline NAECA Combination & 58.6 & 32.3 & 90.9 & 1397 & 6034 & 7431 & 52.0 & 2.2 \\
\hline ASHRAE & 48.3 & 35.4 & 83.7 & 1507 & 7049 & 8556 & 54.1 & 2.4 \\
\hline ASHRAE + NAECA & 45.4 & 32.3 & 77.7 & 1309 & 6034 & 7343 & 48.0 & 2.0 \\
\hline MEC & 59.2 & 35.4 & 94.6 & 1596 & 7049 & 8645 & 57.0 & 2.6 \\
\hline $\mathrm{MEC}+\mathrm{NAECA}$ & 55.5 & 32.3 & 87.8 & 1388 & 6034 & 7422 & 51.4 & 2.2 \\
\hline
\end{tabular}

† Appliance energy includes domestic water heating and cooking of appropriate fuel for each location. 
Table 14. End Use Energy Consumption Under Efficiency Standard Combinations

\begin{tabular}{|c|c|c|c|c|c|c|c|c|}
\hline \multirow{2}{*}{$\begin{array}{l}\text { City and } \\
\text { Standards Case }\end{array}$} & \multicolumn{3}{|c|}{$\begin{array}{c}\text { Natural Gas } \\
\text { Consumption (MMBtu/yr) }\end{array}$} & \multicolumn{3}{|c|}{$\begin{array}{c}\text { Electricity } \\
\text { Consumption }(\mathrm{kWh} / \mathrm{yr})\end{array}$} & \multirow{2}{*}{$\begin{array}{c}\text { Peak } \\
\text { Heat } \\
(\mathrm{kBtu} / \mathrm{hr})\end{array}$} & \multirow{2}{*}{$\begin{array}{l}\text { Peak } \\
\text { Cool } \\
(\mathrm{kW})\end{array}$} \\
\hline & Heat & Appliance $\dagger$ & Total & Cool & Appliance $†$ & Total & & \\
\hline \multicolumn{9}{|l|}{ Albuquerque } \\
\hline NAECA Appliance & 41.1 & 25.8 & 66.9 & 1307 & 5624 & 6931 & 39.8 & 1.8 \\
\hline NAECA Equipment & 36.2 & 28.3 & 64.5 & 1217 & 6639 & 7856 & 36.4 & 1.6 \\
\hline NAECA Combination & 37.5 & 25.8 & 63.3 & 1167 & 5624 & 6791 & 36.3 & 1.5 \\
\hline ASHRAE & 33.4 & 28.3 & 61.7 & 1302 & 6639 & 7941 & 37.1 & 1.7 \\
\hline ASHRAE + NAECA & 31.8 & 25.8 & 57.6 & 1108 & 5624 & 6732 & 33.8 & 1.5 \\
\hline MEC & 39.4 & 28.3 & 67.7 & 1359 & 6639 & 7998 & 39.9 & 1.8 \\
\hline MEC + NAECA & 37.2 & 25.8 & 63.0 & 1159 & 5624 & 6783 & 36.3 & 1.5 \\
\hline \multicolumn{9}{|l|}{ Phoenix } \\
\hline Base Case & 11.4 & 23.8 & 35.2 & 5530 & 6639 & 12169 & 33.2 & 4.1 \\
\hline NAECA Appliance & 12.1 & 21.7 & 33.8 & 5378 & 5624 & 11002 & 33.4 & 4.1 \\
\hline NAECA Equipment & 10.4 & 23.8 & 34.2 & 4748 & 6639 & 11387 & 30.3 & 3.5 \\
\hline NAECA Combination & 11.0 & 21.7 & 32.7 & 4619 & 5624 & 10243 & 30.5 & 3.5 \\
\hline ASHRAE & 10.7 & 23.8 & 34.5 & 5450 & 6639 & 12089 & 32.4 & 4.1 \\
\hline ASHRAE + NAECA & 10.3 & 21.7 & 32.0 & 4548 & 5624 & 10172 & 29.8 & 3.5 \\
\hline MEC & 11.4 & 23.8 & 35.2 & 5530 & 6639 & 12169 & 33.2 & 4.1 \\
\hline MEC + NAECA & 11.0 & 21.7 & 32.7 & 4619 & 5624 & 10243 & 30.5 & 3.5 \\
\hline \multicolumn{9}{|l|}{ Seattle } \\
\hline Base Case & 85.6 & 0.0 & 85.6 & 1047 & 13119 & 14166 & 63.1 & 3.3 \\
\hline NAECA Appliance & 87.4 & 0.0 & 87.4 & 1029 & 11788 & 12817 & 63.1 & 3.2 \\
\hline NAECA Equipment & 78.1 & 0.0 & 78.1 & 972 & 13119 & 14091 & 57.6 & 2.8 \\
\hline NAECA Combination & 79.8 & 0.0 & 79.8 & 957 & 11788 & 12745 & 57.6 & 2.7 \\
\hline ASHRAE & 64.4 & 0.0 & 64.4 & 970 & 13119 & 14089 & 55.6 & 3.0 \\
\hline ASHRAE + NAECA & 60.4 & 0.0 & 60.4 & 892 & 11788 & 12680 & 50.8 & 2.5 \\
\hline \multicolumn{9}{|l|}{ San Francisco } \\
\hline Base Case & 41.7 & 30.0 & 71.7 & 633 & 7074 & 7707 & 43.0 & 3.0 \\
\hline NAECA Appliance & 43.0 & 27.4 & 70.4 & 629 & 6096 & 6725 & 43.1 & 3.0 \\
\hline NAECA Equipment & 38.0 & 30.0 & 68.0 & 607 & 7074 & 7681 & 39.3 & 2.6 \\
\hline NAECA Combination & 39.3 & 27.4 & 66.6 & 604 & 6096 & 6700 & 39.4 & 2.5 \\
\hline ASHRAE & 33.0 & 30.0 & 63.0 & 612 & 7074 & 7686 & 40.3 & 2.9 \\
\hline ASHRAE + NAECA & 31.2 & 27.4 & 58.6 & 583 & 6096 & 6679 & 36.9 & 2.4 \\
\hline \multicolumn{9}{|l|}{ Los Angeles } \\
\hline Base Case & 19.5 & 27.3 & 46.9 & 861 & 7074 & 7935 & 40.1 & 4.1 \\
\hline NAECA Appliance & 20.4 & 24.9 & 45.3 & 836 & 6096 & 6932 & 40.3 & 4.1 \\
\hline NAECA Equipment & 17.8 & 27.3 & 45.2 & 787 & 7074 & 7861 & 36.6 & 3.5 \\
\hline NAECA Combination & 18.6 & 24.9 & 43.5 & 766 & 6096 & 6862 & 36.8 & 3.5 \\
\hline ASHRAE & 15.1 & 27.3 & 42.5 & 838 & 7074 & 7912 & 37.1 & 3.9 \\
\hline ASHRAE + NAECA & 14.5 & 24.9 & 39.4 & 729 & 6096 & 6825 & 34.1 & 3.3 \\
\hline
\end{tabular}

† Appliance energy includes domestic water heating and cooking of appropriate fuel for each location. 
use than is the Model Energy Code in all but Fort Worth. For the ASHRAE Standard, the greatest savings (35\% or $37.9 \mathrm{MMBtu} / \mathrm{yr}$ ) are found in Minneapolis. In the other colder climates, such as Boston, Chicago, Kansas City, Denver and Seattle, the thermal requirements of ASHRAE 90 reduce heating energy use by an average of $22 \mathrm{MMBtu} / \mathrm{yr}$, or $27 \%$. The ASHRAE Standard also reduces peak gas usage for space heating. The range of peak savings is $2-16 \%$. The greatest peak savings are found in Minneapolis (8.8 kBtu/hr) and Chicago (8.1 $\mathrm{kBtu} / \mathrm{hr})$.

In Fort Worth, the Model Energy Code will save about $31 \%$ (12.0 MMBtu) of the annual gas space heating consumption. However, this appears to be a special condition. The typical percentage savings for locations where the MEC requirements challenge current building practices are 17 to $18 \%$ in Minneapolis and Boston, respectively. The savings in Fort Worth are related to the specific requirements of the Model Energy Code. The ASHRAE Standard requires an R-28 ceiling, $R-16$ wall, single glazed windows, and $R-5$ ( $2 \mathrm{ft}$ deep) slab-on-grade foundations, while the MEC requires an R-23 ceiling, an overall wall thermal value of R-6, and R-6 insulation on the slab. The tradeoff between window and wall insulation levels leads to greater requirements in the Fort Worth house, and in the Fort Worth climate will save an additional 9.5 MMBtu/yr above the ASHRAE standard.

The space heating effects of the NAECA are shown in Figure 5, as well as in Table 14. The NAECA appliance standards effect space heat consumption by reducing internal gains, and thus will increase the heating load during the months where heating is required. Over the range of climates analyzed here, the package of efficiency improvements in typical residential appliances under the NAECA standards will increase heating energy use between 0.1 and 2 MMBtu/yr, or between 2 and $6 \%$. These changes are small compared to the overall total space heating consumption. On the other hand, improved furnace efficiency required under NAECA, or the NAECA equipment standards, shows an annual savings of $9 \%$ in all locations, and is the direct result of an increase in the minimum AFUE of natural gas furnaces. This $9 \%$ improvement results in annual savings of over $9 \mathrm{MMBtu}$ in Minneapolis and Chicago, and $8 \mathrm{MMBtu}$ in Boston. The average gas peak savings resulting from improved equipment efficiencies is also found to be $9 \%$. The greatest peak space heat savings, $5.9 \mathrm{kBtu} / \mathrm{hr}$, are found in Chicago.

The space heating savings of the equipment standards under NAECA more than offset the increased space heating from the appliance standards. The combined effect of NAECA is a savings in space heating consumption of $3 \%$ in warmer climates to $7 \%$ in the colder climates. Peak heating energy use is also reduced by the combined NAECA standards, ranging from 8 to $11 \%$.

The combined effects of the thermal codes and the NAECA provide the greatest impact on annual heating energy use, as shown in Figure 6. The savings from the NAECA standards slightly reduce the potential savings from the envelope standards by a few percentage points. The estimated annual space heating reduction ranges from $10 \%$ (1.1 MMBtu/yr) in Phoenix to $39 \%$ (42.3 MMBtu/yr) in Minneapolis. Boston and Chicago also show significant savings in 
Figure 4. Space Heating Gas Use with Envelope Standards

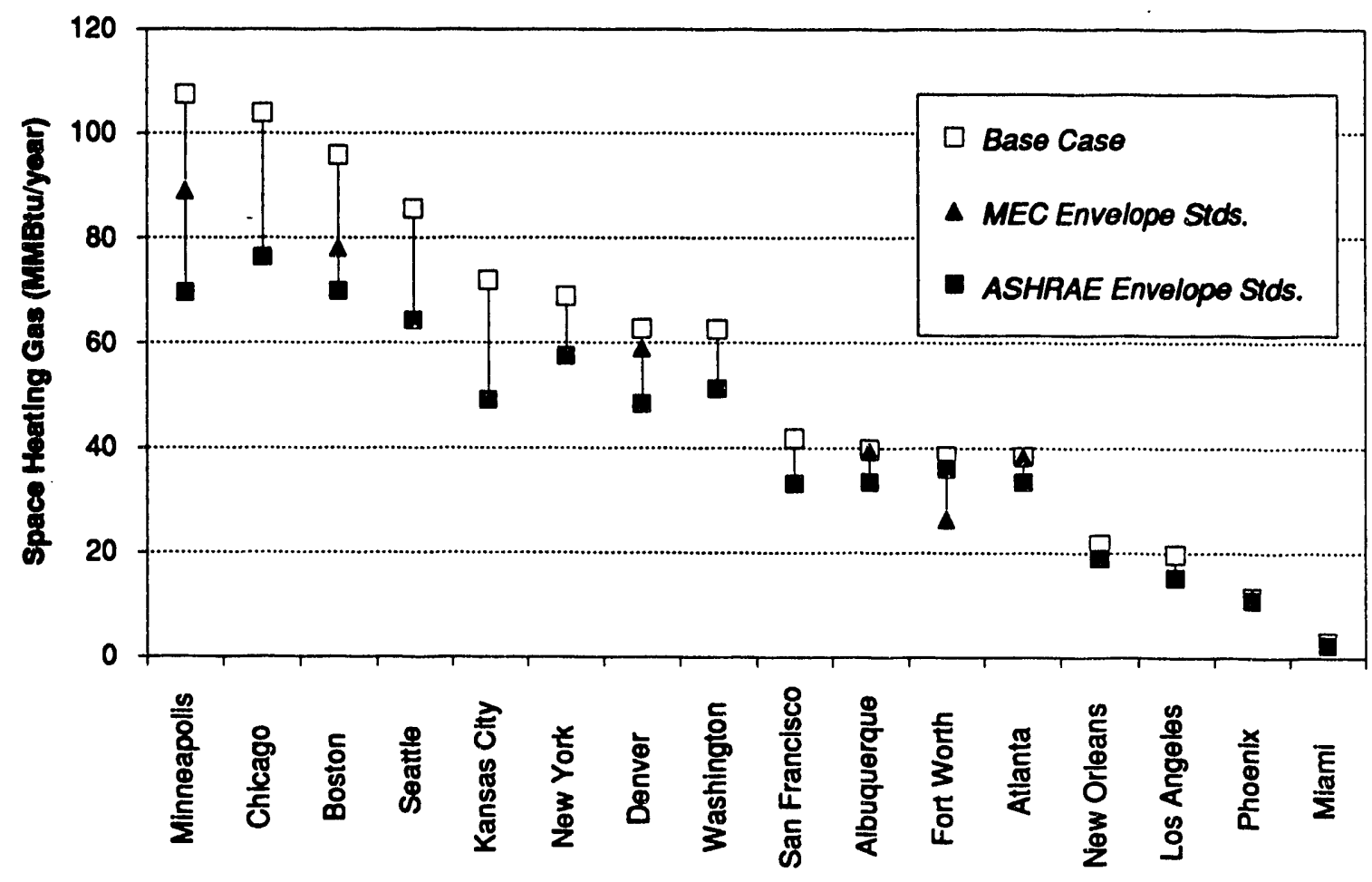

Figure 5. Space Heating Gas Use with NAECA Standards

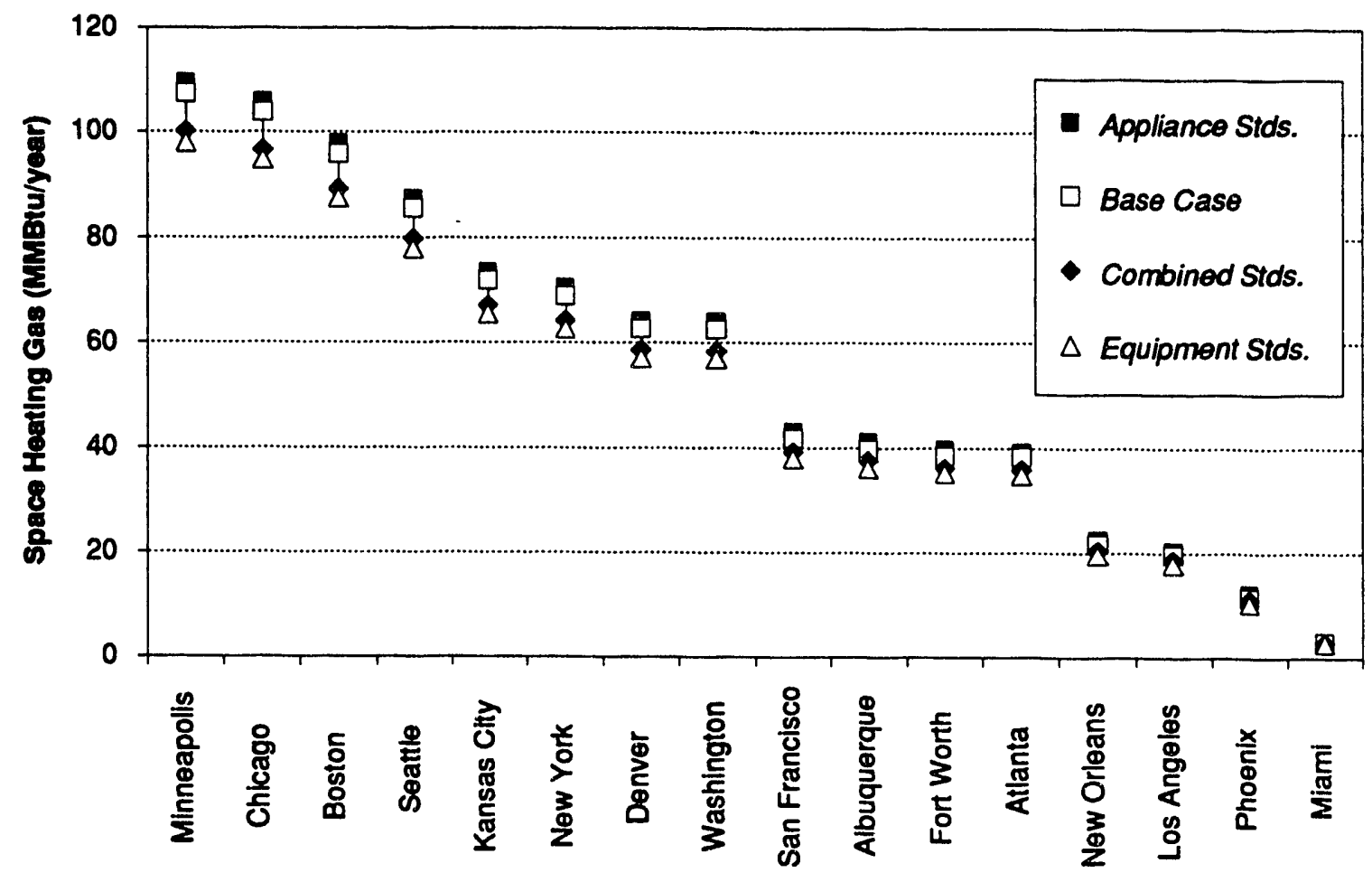


Figure 6. Space Heating Gas Use with Combination Standards

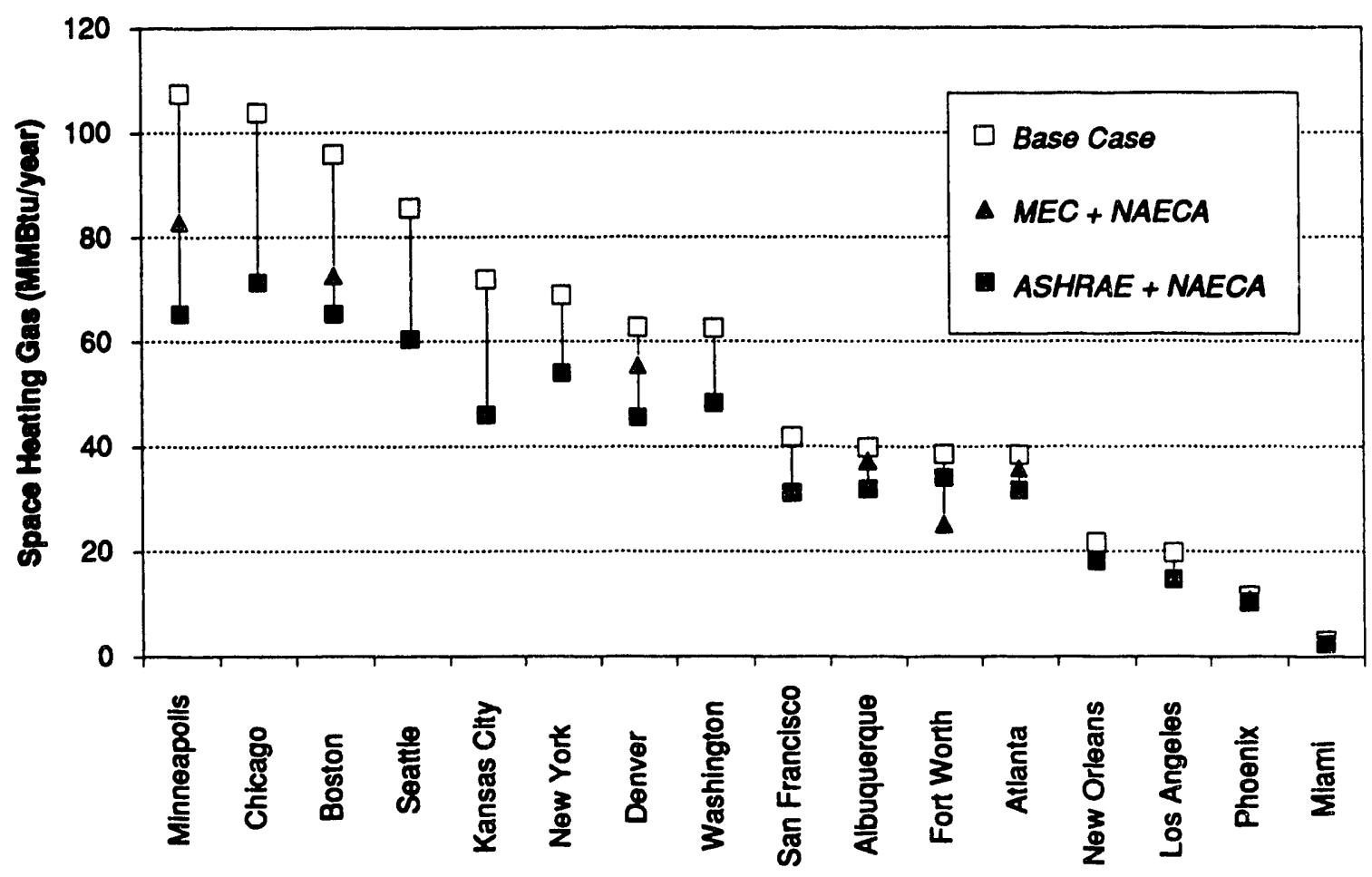

Figure 7. Appliance Gas Use with NAECA Standards

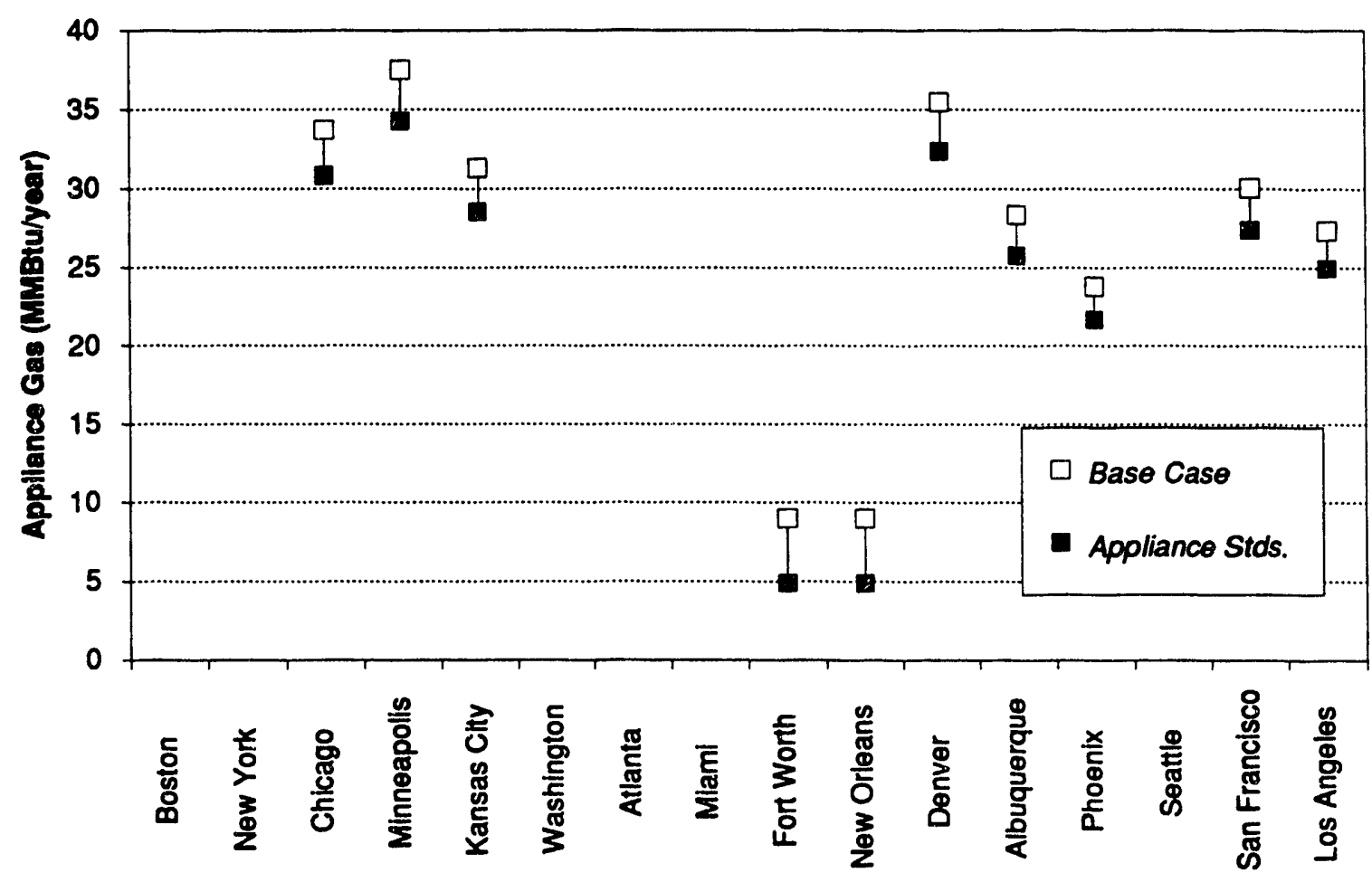


gas space heating of $30.6 \mathrm{MMBtu} / \mathrm{yr}(32 \%)$ and $32.6 \mathrm{MMBtu} / \mathrm{yr}(31 \%)$, respectively. The peak space heating savings as given in Table 14 range from $10 \%(3.4 \mathrm{kBtu} / \mathrm{hr})$ in Phoenix to $24 \%$ $(13.6 \mathrm{kBtu} / \mathrm{hr}$ ) in Minneapolis. Substantial peak savings are also found in Chicago (13.3 $\mathrm{kBtu} / \mathrm{hr})$, Seattle $(12.3 \mathrm{kBtu} / \mathrm{hr})$, and Boston $(11.5 \mathrm{kBtu} / \mathrm{hr})$ as a result of the combined requirements of ASHRAE and NAECA. While the savings are greater with ASHRAE and NAECA than with the MEC and NAECA from stronger thermal requirements, the gas savings with the MEC and NAECA combination are quite substantial in Minneapolis (24.4 MMBtu/yr) and Boston (23.1 MMBtu/yr). The greatest peak savings for the combined MEC and NAECA are found in Fort Worth $(25 \%$ or $11.2 \mathrm{kBtu} / \mathrm{hr})$.

\section{Effects on Appliance Gas Use}

The only end uses considered under the appliance end uses are water heating and cooking. We show these impacts in Figure 7. For Fort Worth and New Orleans, the savings are from improvements to the gas cooking end use under NAECA which eliminated the standing gas pilot on stoves and ovens. For the other cities where gas appliance data are shown, all of the energy use is for water heating. The water heater standards provide savings in water heating energy use of approximately $9 \%$ across all locations, which is a direct result of improvements in the water heating Energy Factor (EF) from 51.2 to 56.1 as required under NAECA.

\section{STANDARDS IMPACTS ON ELECTRICITY CONSUMPTION}

In this section we describe the effects of the codes on annual electricity consumption and peak electricity use for cooling. As in the case of natural gas usage, we consider two major end uses; cooling and non-HVAC electricity, which includes lighting, water heating, and other appliances.

\section{Effects on Cooling Energy Consumption}

The energy-related effects of the thermal and appliance standards on the cooling energy use are very different from those of the heating energy use summarized above (see Table 14 for energy impacts and Appendix A for the load impacts). The most important difference between standard impacts on cooling as compared to heating is that the provisions of the NAECA generally result in greater cooling savings than do the thermal requirements of the ASHRAE 90 Standard and Model Energy Code.

As shown in Figure 8, the envelope codes had small, yet varied, effects on space cooling. The savings are greatest in the south and west, and negative in the north and midwest. The range of annual space cooling energy savings for the ASHRAE Standard are 5\% to $-6 \%$ with a maximum savings of $143 \mathrm{kWh} / \mathrm{yr}$ in New Orleans. In some climates, namely Boston, Chicago, Kansas City, and Minneapolis, the ASHRAE Standard actually increases electricity used for cooling compared to the base case condition. This increase in space cooling ranges from +138 $\mathrm{kWh} / \mathrm{yr}$ in Chicago to $+196 \mathrm{kWh} / \mathrm{yr}$ in Kansas City. These energy penalties occur in climates 
Figure 8. Cooling Electricity Use with Envelope Standards

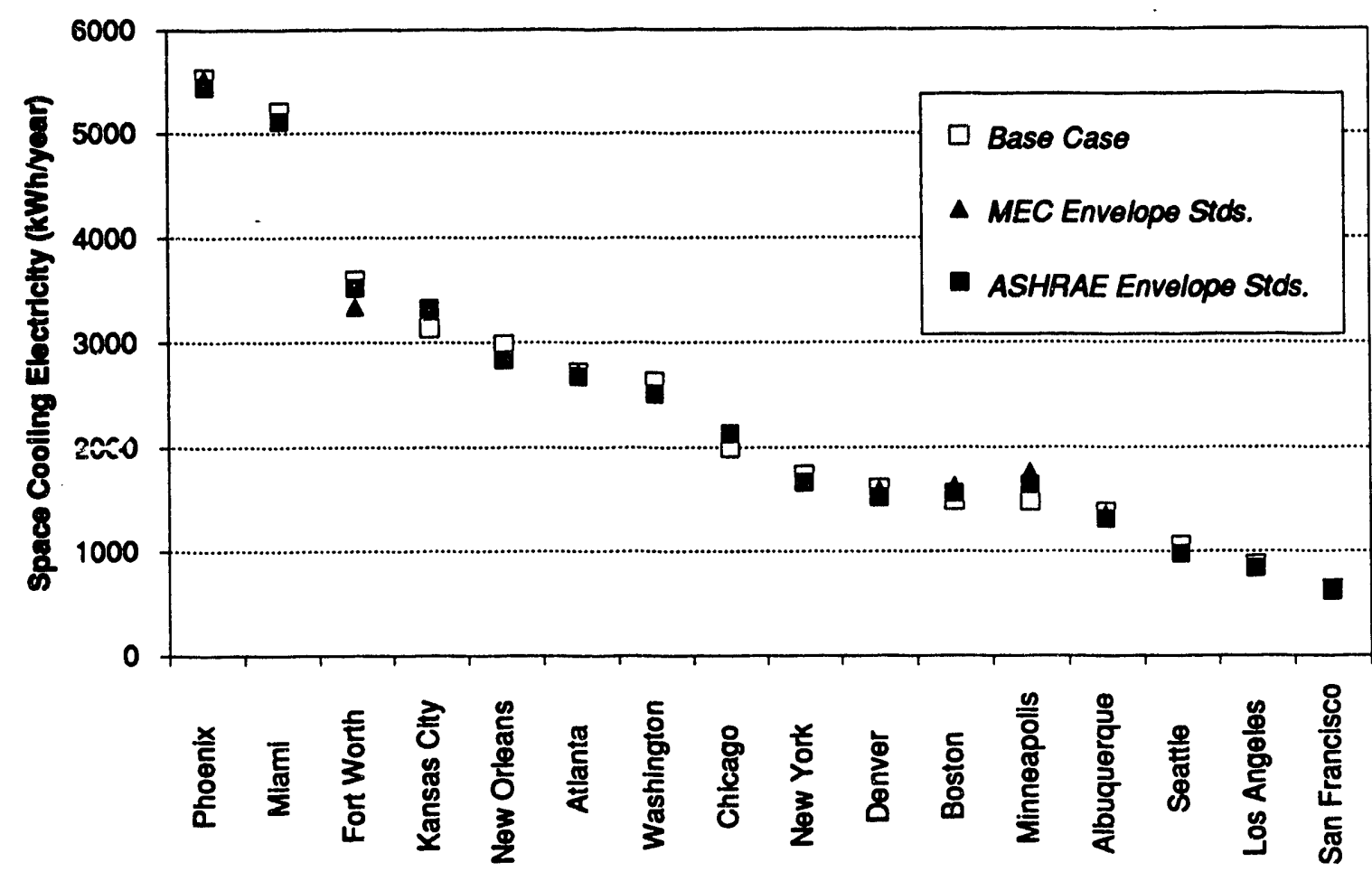

Figure 9. Cooling Electricity Use with NAECA Standards

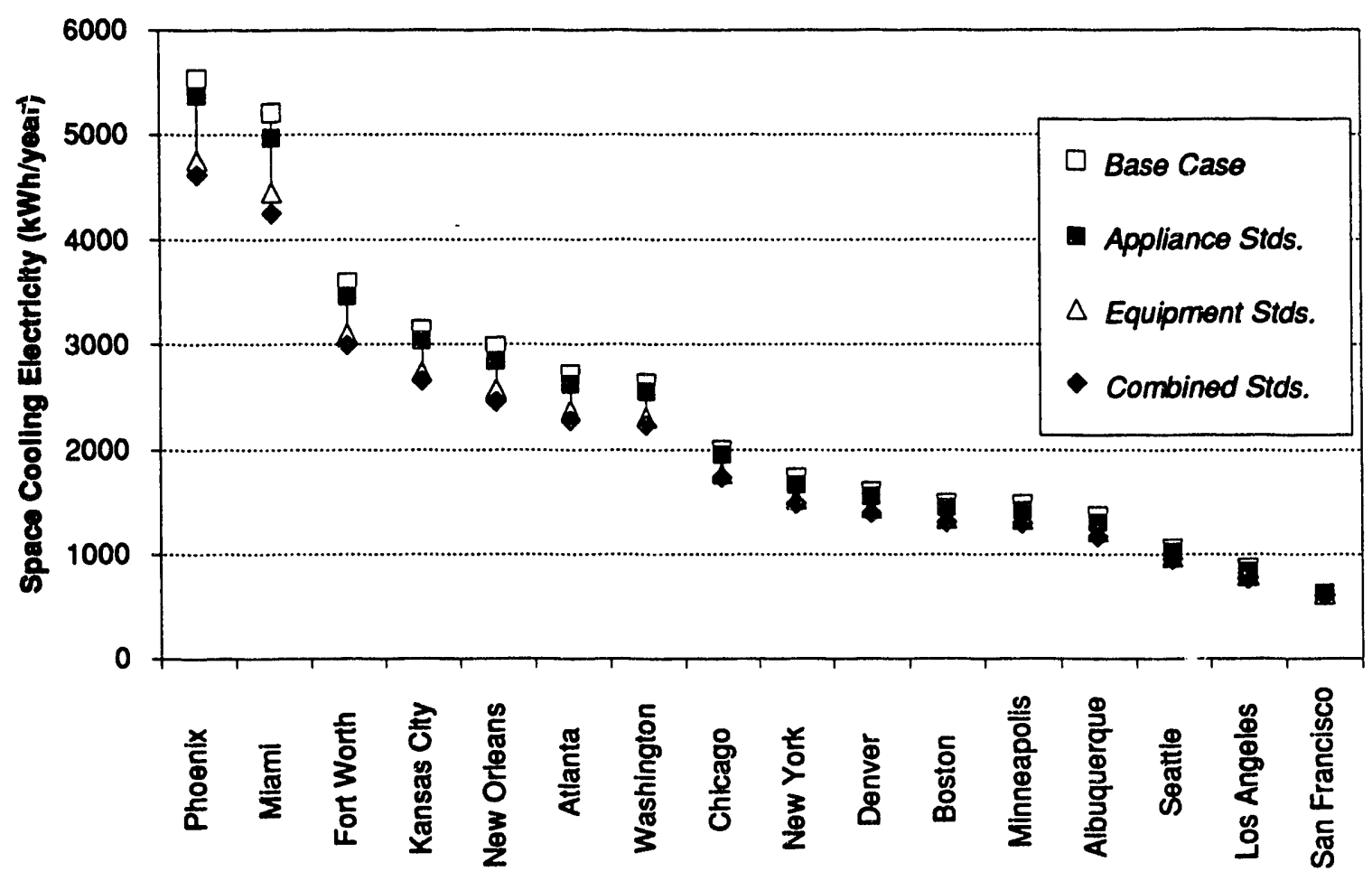


Figure 10. Cooling Electricity Use with Combination Standards

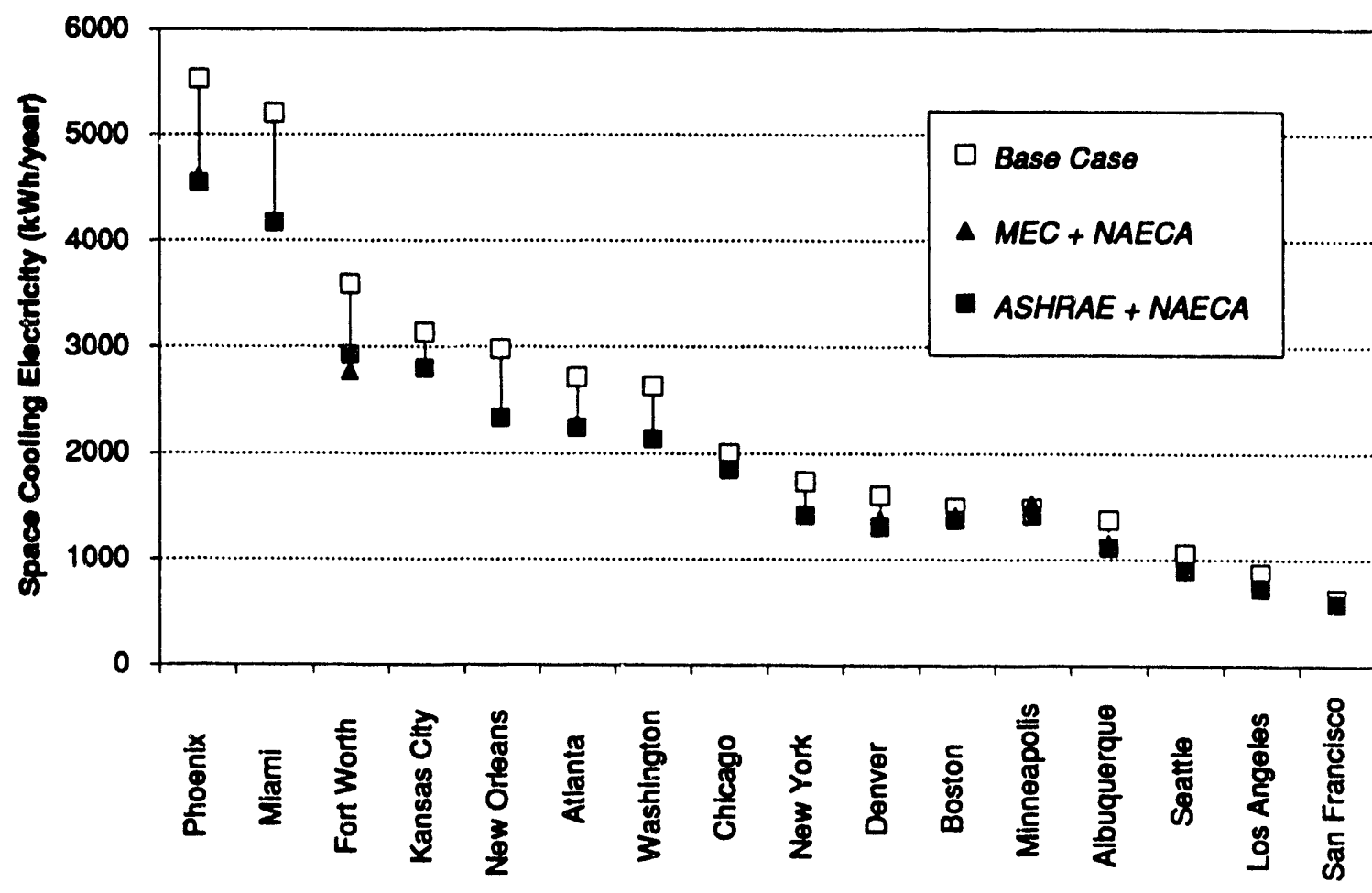

Figure 11. Appliance Electricity Use with NAECA Standards

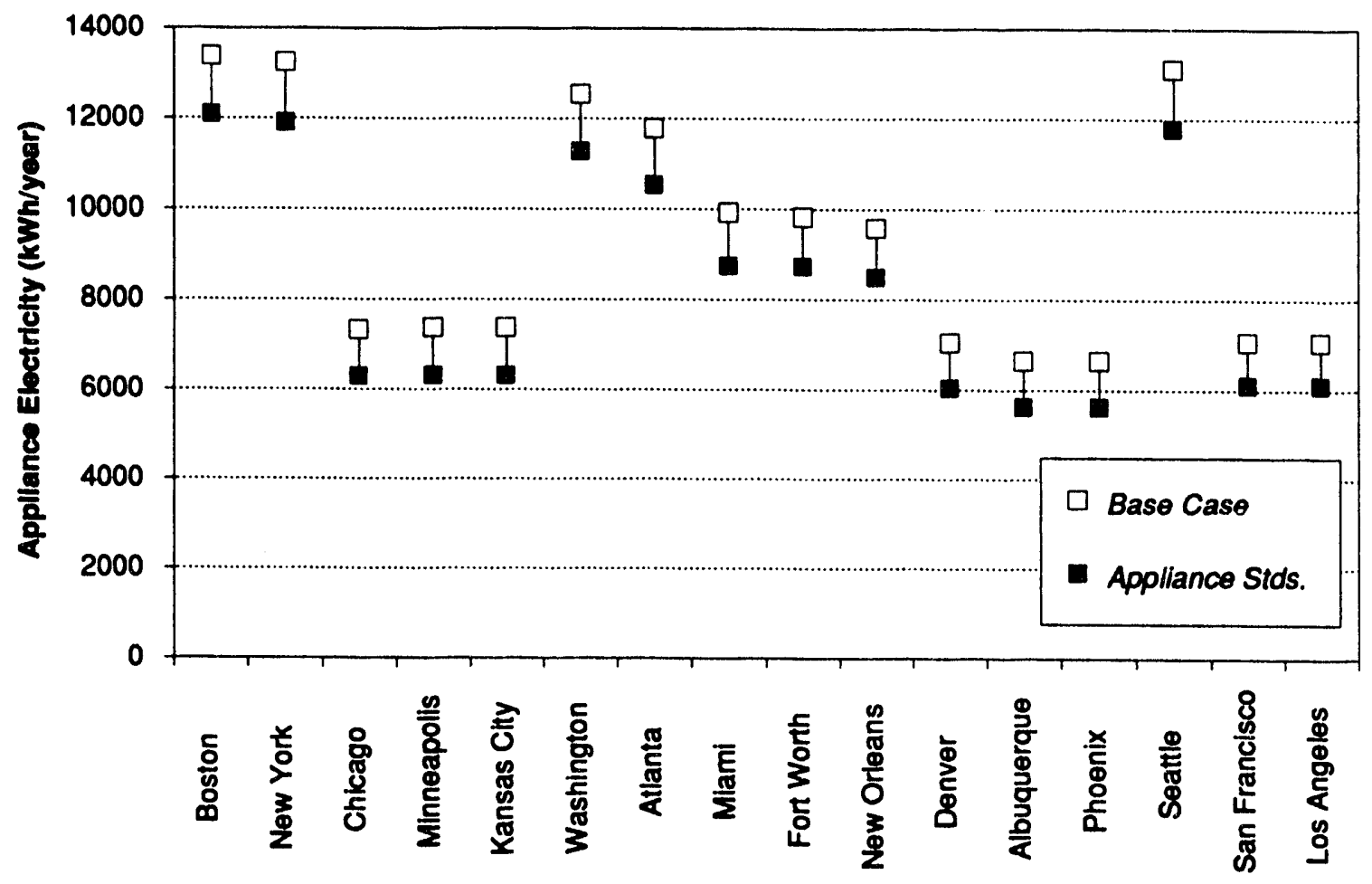


with colder winters, but with some cooling energy demand during the summer. This increase in cooling energy use is due to the change in balance point temperature that the ASHRAE thermal standard creates. That is, as the building's envelope becomes tighter in these colder climates, which is a beneficial feature during the winter months, it can also result in greater demand for cooling energy during the summer periods. The effects of the thermal codes on peak cooling with electricity are also quite small. In the typical case, the envelope standards shave 0.1 to $0.2 \mathrm{~kW}$ from the peak.

As with the calculations of natural gas usage, the effects of appliance changes are distinguished from those for the air-conditioner's efficiency (SEER, or Seasonal Energy Efficiency Rating), and are shown in Figure 9. In all cases, the effect of improved efficiencies for space cooling equipment is to reduce annual cooling electricity usage by $15-18 \%$ in the warm climates, leading to significant energy savings in Phoenix (780 kWh), Miami (750 kWh), and Fort Worth (485 $\mathrm{kWh}$ ). The cooling savings from appliance efficiency impror ements, which result in decreased internal gains, are relatively small, and range from $1-4 \%$. The greatest annual cooling savings from the decreased internal gains are in Miami $(230 \mathrm{kWh})$, Phoenix (150 kWh), New Orleans (130 kWh), and Fort Worth (130 kWh). The combined appliance and equipment efficiency improvements have significant savings in annual space cooling energy use. The hot climates showed the highest potential annual savings: Phoenix (910 kWh), Miami (950 kWh), Fort Worth (590 kWh), New Orleans (520 kWh), and Kansas City $(480 \mathrm{kWh})$.

Improvements in appliance efficiencies, or decreases in internal gains, have a negligible impact on electric cooling peaks, but improved cooling equipment efficiencies reduce peak electricity demand by $0.3-0.6 \mathrm{~kW}$, with the greatest savings in Phoenix, Boston, and Kansas City. In each city, the full provision of the NAECA resulted in a peak savings of $0.6 \mathrm{~kW}$ (about $18 \%)$.

The combined electricity savings for cooling from thermal envelope and the NAECA standards are greater than those from the individual measures, and are shown in Figure 10. These savings range from $22 \%(644 \mathrm{kWh} / \mathrm{yr})$ in New Orleans, to $20 \%(1030 \mathrm{kWh} / \mathrm{yr})$ in Miami and $18 \%(980 \mathrm{kWh} / \mathrm{yr})$ in Phoenix. Net cooling electricity savings are even possible in those climates that have increased cooling demands from the envelope standards because of the improved equipment efficiencies. The combined thermal standards and appliance and equipment standards are also effective in reducing peak energy use by 0.4 to $0.7 \mathrm{~kW}$.

\section{Effects on Non-HVAC Electricity Consumption}

The effects of the standards on non-HVAC electricity use are determined by the type of domestic hot water system (natural gas or electric), the hot water loads, appliance saturations, and the type of cooking fuel. As shown in Figure 11, the savings from the improved appliance efficiency range from $980 \mathrm{kWh}$ in Los Angeles, with gas water heat, to $1360 \mathrm{kWh}$ in New York, with electric water heat. The warmer cities, such as Miami and Phoenix, do not have as 
much savings in appliances because in Miami, the water heating load is smaller due to warmer incoming cold water temperature is greater, while in Phoenix, we assume gas water heating.

\section{SUMMARY OF INTERNAL GAINS INTERACTIONS}

By simulating the reduced internal gains from appliances under the NAFCA standards, we are able to quantify the effects of improved appliance efficiency on heating anc covling loads in new single family buildings. A summary of the impacts are presented in Table 15. The impact of reduced gains on the heating or cooling load is related to the length of the heating or cooling season. Hence, these results apply only to new buildings with these levels of thermal integrity. Since these buildings are new, and relatively well-insulated, the heating and cooling seasons are typically shorter than older buildings. In older buildings, the impact of changes in internal gains would be greater than those shown here.

Figure 12 shows the fractional change in heating and cooling loads given a unit change in internal gains. The cities are ranked in order from left to right of decreasing base case heating energy consumption. In Minneapolis about $60 \%$ of the reduction in heat gain appears as increased heating load, while only $4 \%$ does so in Miami. Alternatively, $70 \%$ of the reduction in internal gains appears as reduced cooling load in Miami. Any appliance standards will thus have an obvious double benefit in cooling-dominated climates but the net energy savings are less than $100 \%$ of appliance savings in areas where heating is more important.

\section{TOTAL HOUSE ENERGY SAVINGS}

By looking at the potential energy savings across all end-uses we can understand the relative impacts the various standards may have on future energy use in the single family sector. The total potential savings for a variety of code combinations are presented in Table 16. Because the effects of the standards on household energy use are dominated by the type of domestic hot water system (natural gas or electric), appliance saturations, and the type of cooking fuel, the table is sorted by fuel type for those appliances.

Table 16 shows that in the best case, with the ASHRAE envelope measures and full provisions of NAECA, electricity savings are 1000 to $2000 \mathrm{kWh} /$ year in the cities with gas water heat and 1400 to $2200 \mathrm{kWh} /$ year in the cities with electric water heat, depending on the climate. The reductions in electricity consumption are dominated by the various appliance standards resulting from NAECA except in the extreme cooling climates where cooling electricity consumption becomes a significant portion of the overall electricity bill. Electricity savings can be approximated across locations as $1100 \mathrm{kWh} /$ year from household appliances, 200 $\mathrm{kWh} /$ year from water heating where applicable, and between 0 and $700 \mathrm{kWh} /$ year from cooling.

Overall, the potential savings in natural gas are dominated by space heating energy reductions (in gas heated buildings) from building envelope measures in the colder climates. 
Table 15. Change in Heating and Cooling Loads and Energy Use from Changes in Internal Gains

\begin{tabular}{|l|cc|c|cc|cc|}
\hline & \multicolumn{2}{|c|}{$\begin{array}{c}\text { Base Case } \\
\text { City }\end{array}$} & $\begin{array}{c}\Delta \\
\text { Heating }\end{array}$ & $\begin{array}{c}\text { Cooling } \\
\text { (MMBtu/yr) }\end{array}$ & $\begin{array}{c}\Delta \text { LWh/yr) } \\
\text { Internal Gains } \\
(\mathrm{MMBtu} / \mathrm{yr})\end{array}$ & $\begin{array}{c}\text { Heating Cooling } \\
\text { (MMBtu/yr) }\end{array}$ & \multicolumn{2}{c|}{$\begin{array}{c}\text { Delta Energy } \\
\text { Heating } \\
(\mathrm{MMBtu} / \mathrm{yr})\end{array}$} & $\begin{array}{c}\text { Cooling } \\
(\mathrm{kWh} / \mathrm{yr})\end{array}$ \\
\hline Minneapolis & 107.5 & 1473 & -2.6 & 1.5 & -0.4 & 2.1 & -48 \\
Chicago & 103.9 & 1999 & -2.6 & 1.3 & -0.4 & 2.0 & -50 \\
Boston & 95.9 & 1481 & -2.4 & 1.2 & -0.3 & 1.9 & -31 \\
Seattle & 85.6 & 1047 & -2.5 & 1.4 & -0.2 & 1.8 & -18 \\
Kansas City & 71.9 & 3131 & -2.6 & 1.1 & -0.7 & 1.6 & -90 \\
New York & 68.8 & 1724 & -2.5 & 1.2 & -0.5 & 1.7 & -56 \\
Denver & 62.7 & 1605 & -2.5 & 1.1 & -0.4 & 1.5 & -44 \\
Waskington & 62.6 & 2627 & -2.5 & 1.1 & -0.7 & 1.4 & -84 \\
San Francisco & 41.7 & 633 & -2.5 & 1.0 & 0.0 & 1.3 & -4 \\
Albuquerque & 39.7 & 1366 & -2.5 & 1.0 & -0.5 & 1.4 & -59 \\
Fort Worth & 38.5 & 3589 & -2.6 & 0.8 & -1.0 & 1.2 & -126 \\
Atlanta & 38.2 & 2716 & -2.5 & 0.7 & -0.8 & 1.1 & -103 \\
New Orleans & 21.5 & 2976 & -2.6 & 0.6 & -1.1 & 0.9 & -136 \\
Los Angeles & 19.5 & 861 & -2.5 & 0.5 & -0.2 & 0.9 & -25 \\
Phoenix & 11.4 & 5530 & -2.5 & 0.4 & -1.1 & 0.7 & -152 \\
Miami & 2.9 & 5203 & -2.5 & 0.1 & -1.8 & 0.1 & -232 \\
\hline
\end{tabular}

Note: Cities sorted by base case heating load.

Figure 12. Change in Heating and Cooling Loads with Change in Internal Gains

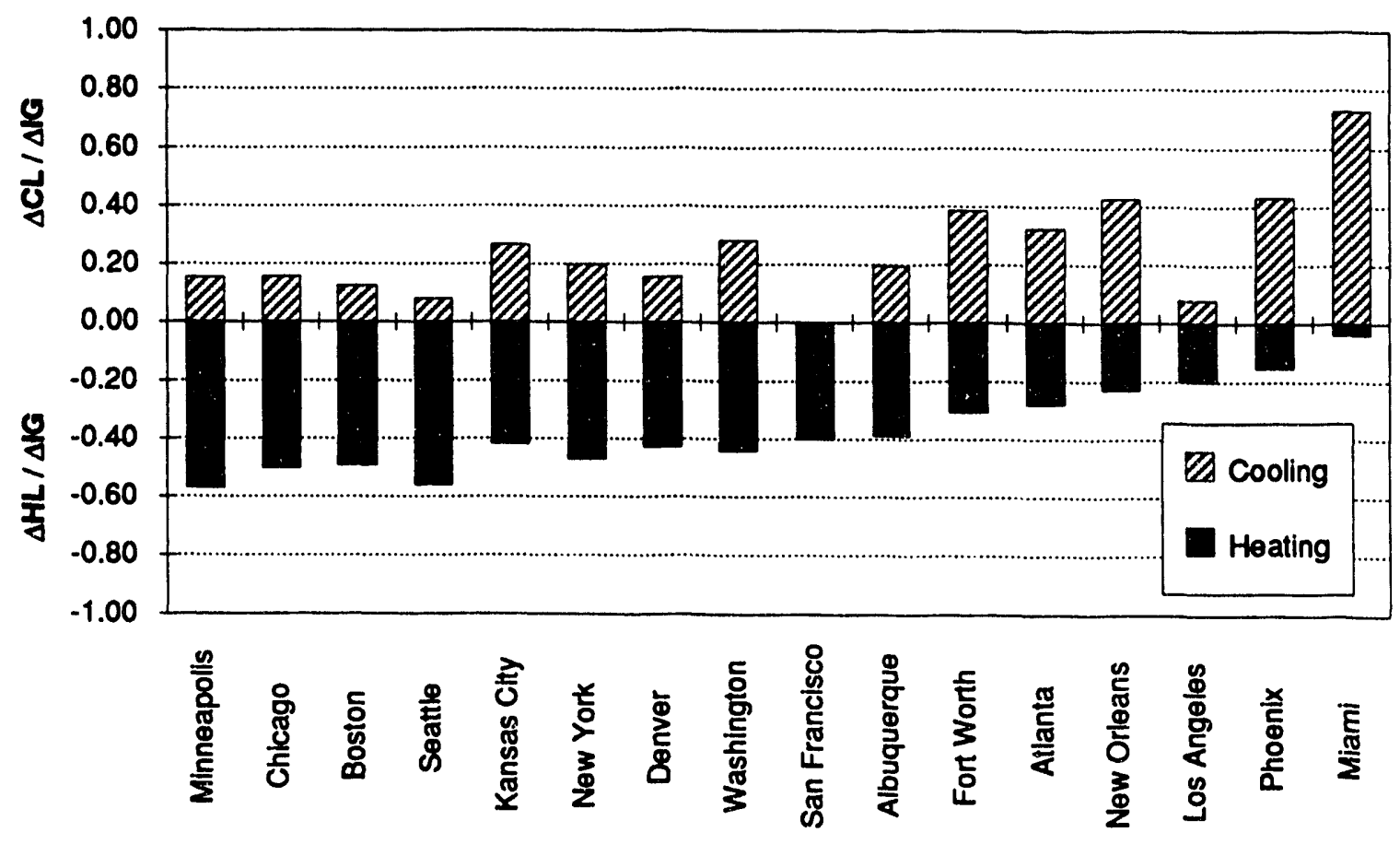

$\Delta \mathrm{G}=$ change in internal gains; $\Delta \mathrm{HL}=$ change in heating load; $\Delta \mathrm{CL}=$ change in cooling load 
Table 16. Base Case Energy Use and Total House Energy Savings from Standards Measures

\begin{tabular}{|c|c|c|c|c|c|c|c|c|c|c|}
\hline \multirow[b]{3}{*}{ City } & \multirow{2}{*}{\multicolumn{2}{|c|}{$\begin{array}{l}\text { Base Case } \\
\text { Energy Use }\end{array}$}} & \multicolumn{8}{|c|}{ Annual Energy Savings } \\
\hline & & & \multicolumn{2}{|c|}{$\begin{array}{c}\text { NAECA } \\
\text { Appliance }\end{array}$} & \multicolumn{2}{|c|}{$\begin{array}{c}\text { NAECA } \\
\text { Combined }\end{array}$} & \multicolumn{2}{|c|}{$\begin{array}{c}\text { ASHRAE+ } \\
\text { NAECA }\end{array}$} & \multicolumn{2}{|c|}{$\begin{array}{c}\text { MEC+ } \\
\text { NAECA }\end{array}$} \\
\hline & $\begin{array}{c}\text { Gas } \\
\text { (MMBiu) }\end{array}$ & $\begin{array}{c}\text { Electric } \\
(\mathbf{k W h})\end{array}$ & $\begin{array}{c}\text { Gas } \\
\text { (MMBtu) }\end{array}$ & $\begin{array}{c}\text { Electric } \\
(\mathrm{kWh})\end{array}$ & $\begin{array}{c}\text { Gas } \\
\text { (MMBiu) }\end{array}$ & $\begin{array}{c}\text { Electric } \\
(\mathbf{k W h})\end{array}$ & $\begin{array}{c}\text { Gas } \\
\text { (MMBtu) }\end{array}$ & $\begin{array}{c}\text { Electric } \\
(\mathbf{k W h})\end{array}$ & $\begin{array}{c}\text { Gas } \\
\text { (MMBtu) }\end{array}$ & $\begin{array}{c}\text { Electric } \\
(\mathbf{k W h})\end{array}$ \\
\hline \multicolumn{11}{|c|}{ Gas DHW/Electric Cooking } \\
\hline Minneapolis & 144.9 & 8800 & 1.2 & 1100 & 10.8 & 1200 & 45.6 & 1100 & 27.6 & 1000 \\
\hline Chicago & 137.6 & 9300 & 1.0 & 1100 & 10.2 & 1300 & 35.5 & 1200 & & \\
\hline Kansas City & 103.2 & 10500 & 1.2 & 1200 & 7.6 & 1500 & 28.7 & 1400 & & \\
\hline Denver & 98.0 & 8700 & 1.5 & 1100 & 7.1 & 1200 & 20.3 & 1300 & 10.2 & 1200 \\
\hline San Francisco & 71.7 & 7700 & 1.3 & 1000 & 5.1 & 1000 & 13.1 & 1000 & & \\
\hline Albuquerque & 68.0 & 8000 & 1.1 & 1100 & 4.7 & 1200 & 10.4 & 1300 & 5.0 & 1200 \\
\hline Los Angeles & 46.9 & 7900 & 1.6 & 1000 & 3.4 & 1100 & 7.5 & 1100 & & \\
\hline Phoenix & 35.2 & 12200 & 1.4 & 1200 & 2.5 & 1900 & 3.2 & 2000 & 2.5 & 1900 \\
\hline \multicolumn{3}{|c|}{ Electric DHW/Electric Cooking } & & & & & & & & \\
\hline Boston & 95.9 & 14900 & -1.9 & 1300 & 6.7 & 1500 & 30.6 & 1400 & 23.1 & 1400 \\
\hline Seattle & 85.6 & 14200 & -1.8 & 1300 & 5.8 & 1400 & 25.2 & 1500 & & \\
\hline New York & 68.8 & 15000 & -1.7 & 1400 & 4.5 & 1600 & 14.9 & 1700 & & \\
\hline Washington & 62.6 & 15200 & -1.4 & 1400 & 4.2 & 1700 & 14.5 & 1800 & & \\
\hline Atlanta & 38.2 & 14500 & -1.1 & 1300 & 2.4 & 1700 & 6.8 & 1700 & 2.4 & 1700 \\
\hline Miami & 2.9 & 15100 & -0.1 & 1400 & 0.1 & 2100 & 0.6 & 2200 & & \\
\hline \multicolumn{3}{|c|}{ Electric DHW/Gas Cooking } & & & & & & & & \\
\hline Fort Worth & 47.5 & 13400 & 2.9 & 1200 & 6.4 & 1700 & 8.7 & 1800 & 17.5 & 1900 \\
\hline New Orleans & 30.5 & 12600 & 3.2 & 1200 & 5.2 & 1600 & 7.7 & 1700 & & \\
\hline
\end{tabular}

Gas space heating and electric air conditioning assumed in all locations.

Combined equipment and appliance savings from NAECA are about $7 \%$ with and without gas water heating, whereas the combined NAECA and ASHRAE envelope measures give $20-30 \%$ savings. Savings from MEC standards, while less than for ASHRAE, are also significant in those cities where the MEC requires increased thermal integrity from current construction practices.

\section{ENERGY COST SAVINGS}

In an attempt to make the analysis more meaningful to the reader, we estimate the energy costs for a few cases. Four cities are selected to represent the monetary effects of the codes on heating and cooling energy use: Chicago and Minneapolis for heating (i.e., natural gas usage), and Atlanta and Washington D.C. for electricity consumption. The cities in our sample are chosen to have similar fuels for all appliances. In each case, the annual energy costs are 
estimated for each standard condition presented in the previous section. The utility costs are taken from an earlier GRI report. ${ }^{32}$

For several reasons these utility costs are considered broad estimates and are provided for illustrative purposes only. First, the energy use estimates from the simulations are based on "average" building characteristics and "average" building operating, conditions and they may vary on a site-specific basis (i.e., between individual houses). Second, utility costs are variable, and may have changed since the publication of the GRI report. Finally, the rate schedule chosen for this analysis is only one choice out of several rate options that are available to any particular residential customer. In all cases, we selected the general rate schedule for residential customers.

As expected, the annual savings of energy costs follow the levels of avoided natural gas or electricity that results from the particular standard in question. In some cases, however, because of the utility rate structure, the implementation of a building code in one city may result in more dollar savings than would be expected from the level of energy saved. In other words, saving less energy in a city with a higher utility rate will make more impact. In every case, we compare the energy costs of a particular code to the annual costs for the base casc house.

The annual cost savings for natural gas usage (space and water heating) are shown in Table 17 and Figure 13 for Minneapolis and Chicago. The estimated annual cost savings of the ASHRAE Standard are $\$ 192$ in Minneapolis and $\$ 97$ in Chicago. These results provide an example of the effects of utility costs. The natural gas savings resulting from the ASHRAE Standard are only $40 \%$ greater in Minneapolis than in Chicago (37.9 MMBtu vs. 27.4 MMBtu, respectively), yet the cost savings in Minneapolis are almost twice as great. The dollar savings for the combined effects of ASHRAE and the NAECA are \$231 in Minneapolis and \$126 in Chicago. As shown, the Model Energy Code savings in Minneapolis are comparable to the ASHRAE savings in Chicago.

The annual cost savings for electric usage are quite different from those for natural gas (see Figure 14 and Table 18). First, the dollar savings for appliances and for equipment are significantly higher than those for the thermal codes (ASHRAE or MEC). For example, the ASHRAE Standard saves about \$2-21/yr, the equipment standard saves $\$ 20-34 / y r$, and the appliance standards save $\$ 50-102 / y r$. In the case of electricity, the appliance measures, taken as a whole, are more effective in reducing annual electricity use (and therefore annual costs) than cooling savings from the improvements in SEER under NAECA.

The greatest annual cost savings are equated to the combination of the ASHRAE standard and the combined NAECA. The annual dollar savings in Atlanta are $\$ 71$, while the combination of ASHRAE and NAECA save $\$ 140$ in Washington, D.C. As in the case of natural gas usage, the effects of the difference in rate schedule is significant. As shown in Table 18, the annual electricity savings in Washington DC for the combined thermal and NAECA standards 
Figure 13. Annual Energy Cost Savings for Natural Gas

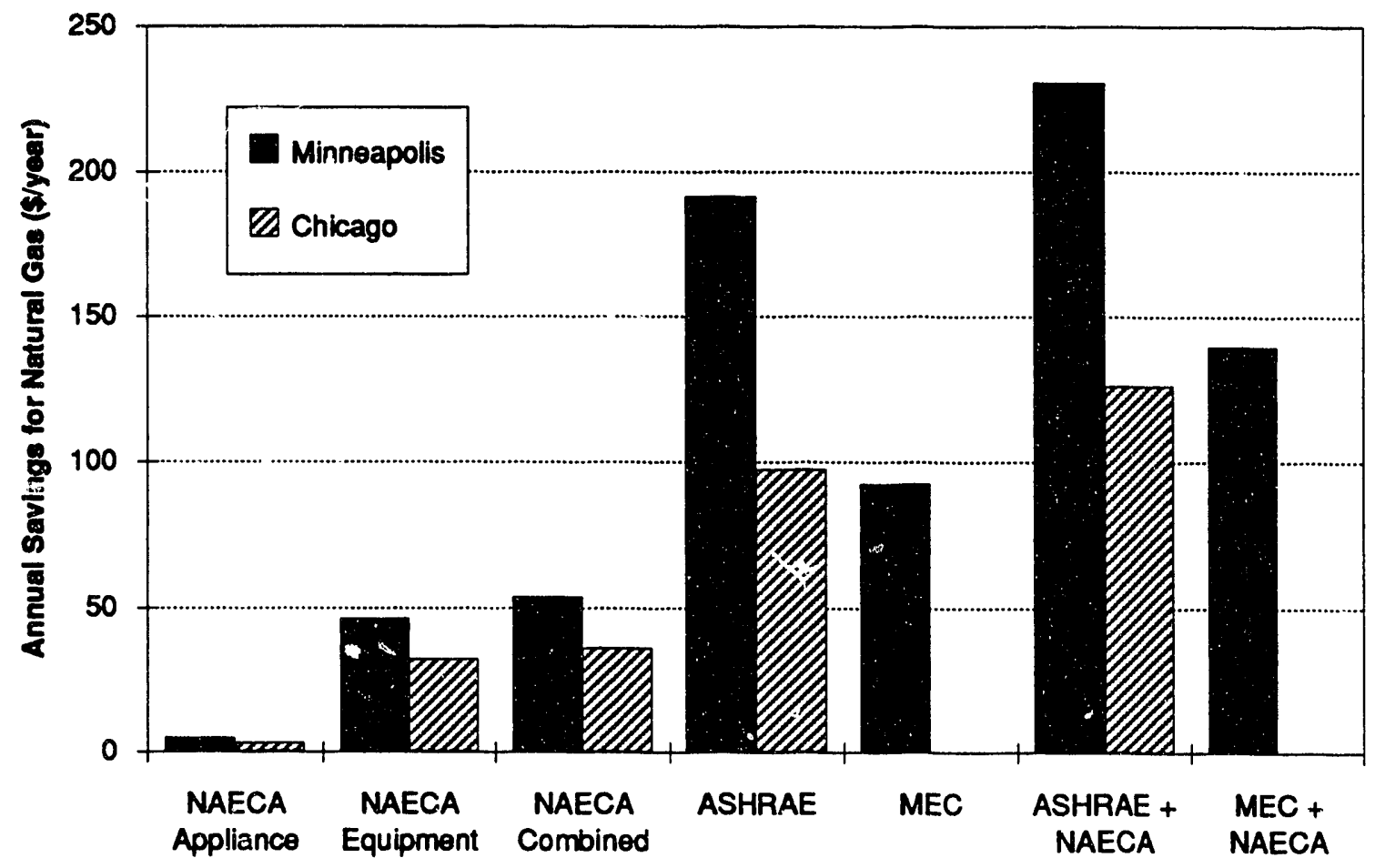

Figure 14. Annual Energy Cost Savings for Electricity

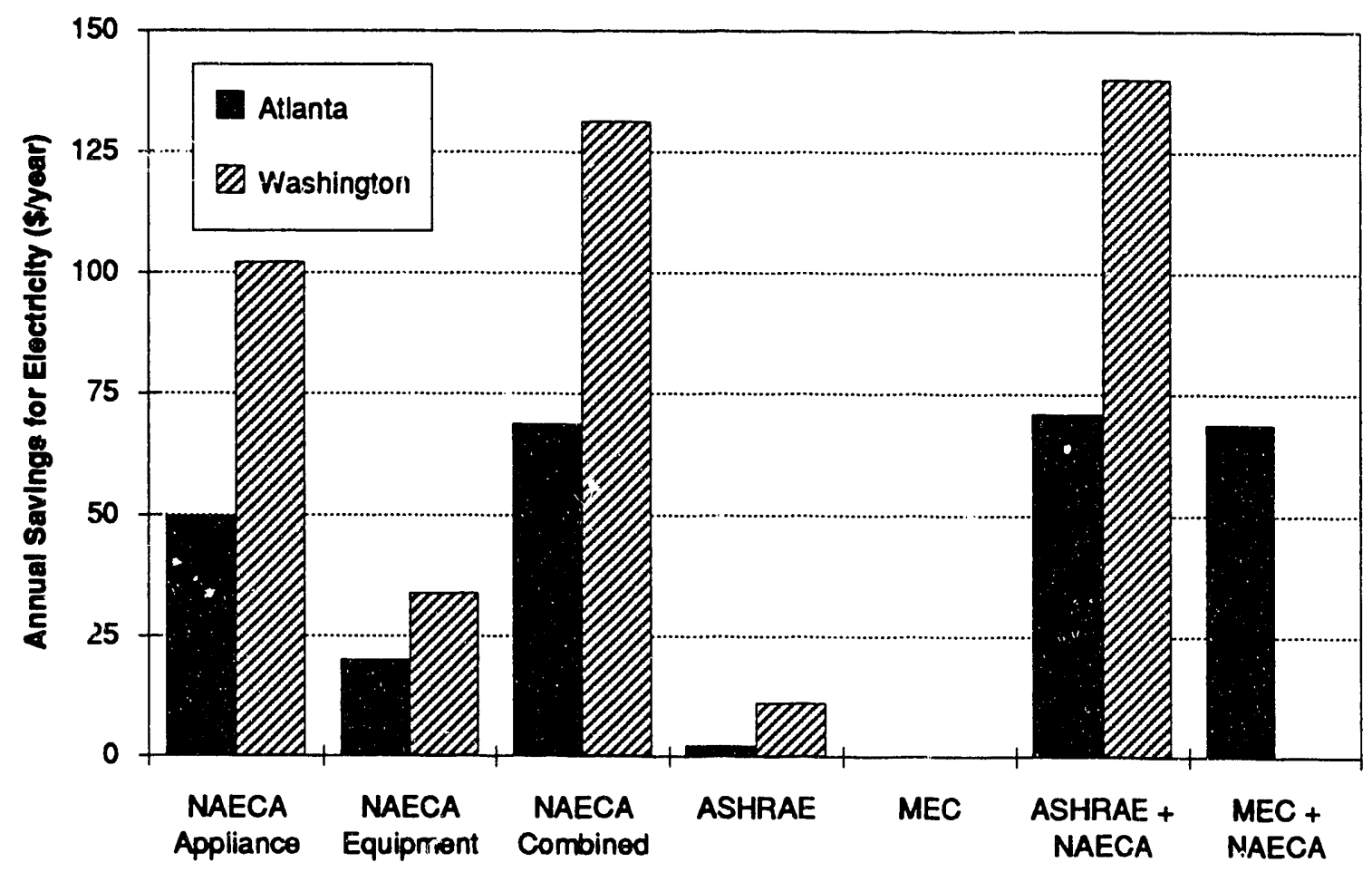


Table 17. Annual Energy Cost Savings for Natural Gas

\begin{tabular}{|l|ccc|cc|}
\hline $\begin{array}{l}\text { City and } \\
\text { Standard Case }\end{array}$ & $\begin{array}{c}\text { Space } \\
\text { Heat } \\
\text { (MMBtu) }\end{array}$ & $\begin{array}{c}\text { Appliance } \\
\text { Gas } \\
\text { (MMBtu) }\end{array}$ & $\begin{array}{c}\text { Total } \\
\text { Gas } \\
\text { (MMBtu) }\end{array}$ & $\begin{array}{c}\text { Annual } \\
\text { Costs } \\
(\$)\end{array}$ & $\begin{array}{c}\text { Annual } \\
\text { Savings } \\
(\$)\end{array}$ \\
\hline Minneapolis & & & & & \\
Base Case & 107.5 & 37.5 & 144.9 & 772 & \\
NAECA Appliance & 109.6 & 34.2 & 143.7 & 767 & 5 \\
NAECA Equipment & 98.1 & 37.5 & 135.5 & 725 & 46 \\
NAECA Combined & 100.0 & 34.2 & 134.1 & 718 & 54 \\
ASHRAE & 69.6 & 37.5 & 107.0 & 580 & 192 \\
MEC & 89.1 & 37.5 & 126.6 & 679 & 92 \\
ASHRAE + NAECA & 65.2 & 34.2 & 99.3 & 541 & 231 \\
MEC+ NAECA & 83.1 & 34.2 & 117.3 & 632 & 140 \\
\hline Chicago & & & & & \\
Base Case & 103.9 & 33.7 & 137.6 & 544 & \\
NAECA Appliance & 105.9 & 30.8 & 136.6 & 541 & 3 \\
NAECA Equipment & 94.8 & 33.7 & 128.5 & 512 & 32 \\
NAECA Combined & 96.6 & 30.8 & 127.4 & 508 & 36 \\
ASHRAE & 76.5 & 33.7 & 110.2 & 447 & 97 \\
ASHRAE + NAECA & 71.3 & 30.8 & 102.1 & 418 & 126 \\
\hline
\end{tabular}

Table 18. Annual Energy Cost Savings for Electricity

\begin{tabular}{|l|ccc|cc|}
\hline $\begin{array}{l}\text { City and } \\
\text { Standard Case }\end{array}$ & $\begin{array}{c}\text { Space } \\
\text { Cool } \\
(\mathrm{kWh})\end{array}$ & $\begin{array}{c}\text { Appliance } \\
\text { Electric } \\
(\mathrm{kWh})\end{array}$ & $\begin{array}{c}\text { Total } \\
\text { Electric } \\
(\mathrm{kWh})\end{array}$ & $\begin{array}{c}\text { Annual } \\
\text { Costs } \\
(\$)\end{array}$ & $\begin{array}{c}\text { Annual } \\
\text { Savings } \\
(\$)\end{array}$ \\
\hline Atlanta & & & & & \\
Base Case & 2716 & 11760 & 14476 & 756 & \\
NAECA Appliance & 2613 & 10527 & 13140 & 706 & 50 \\
NAECA Equipment & 2366 & 11760 & 14126 & 736 & 20 \\
NAECA Combined & 2277 & 10527 & 12804 & 687 & 69 \\
ASHRAE & 2678 & 11760 & 14438 & 754 & 2 \\
MEC & 2716 & 11760 & 14476 & 756 & 0 \\
ASHRAE + NAECA & 2240 & 10527 & 12767 & 685 & 71 \\
MEC + NAECA & 2277 & 10527 & 12804 & 687 & 69 \\
\hline Washington & & & & & \\
Base Case & 2627 & 12547 & 15174 & 1165 & 102 \\
NAECA Appliance & 2543 & 11268 & 13811 & 1063 & 34 \\
NAECA Equipment & 2299 & 12547 & 14846 & 1131 & 131 \\
NAECA Combined & 2228 & 11268 & 13496 & 1034 & 11 \\
ASHRAE & 2508 & 12547 & 15055 & 1154 & 140 \\
ASHRAE + NAECA & 2132 & 11268 & 13400 & 1025 & \\
\hline
\end{tabular}

is $6 \%$ higher than Atlanta, but the annual dollars savings are nearly twice as high. 


\section{5 \\ CONCLUSIONS}

The requirements of the two thermal standards, ASHRAE 90.2P and the Model Energy Code, and the provisions of the NAECA may affect the annual residential energy use in different ways, depending on the type of fuel and end use. In this study these effects were investigated both in isolation (i.e., ASHRAE vs. MEC; appliances vs. equipment), and in combination (ASHRAE or MEC plus appliances and equipment). Several conclusions can be drawn about the individual effectiveness of each energy code, as well as the total impact of all standards:

- The greatest annual energy savings for both natural gas and electricity are from the combination of the ASHRAE Standard and full provisions of the NAECA. In the most extreme climates, the standards can reduce space heat energy use by $31 \%$, or 42 MMBtu for natural gas heat, and can reduce cooling energy use by up to $20 \%$, or $1030 \mathrm{kWh}$ for electric air-conditioning.

- The requirements of the combined ASHRAE Standard and the appliance and equipment provisions in NAECA also provide significant peak savings of natural gas and electricity. Gas peak savings for space heat reach $13.6 \mathrm{kBtu} / \mathrm{hr}(26 \%)$ and electricity peak savings for cooling reach $0.7 \mathrm{~kW}(23 \%)$.

- The ASHRAE 90 Standard has the potential to significantly decrease energy consumption for space heating, particularly in colder climates. The maximum annual gas space heat savings for ASHRAE are 37.9 MMBtu in Minneapolis, the coldest climate studied. Typical savings in colder climates are about 22 MMBtu/yr (27\%). In addition, the ASHRAE standard is more effective in reducing gas space heating energy usage than the Model Energy Code in all but one location (Fort Worth), where the provisions of the Model Energy Code are slightly more stringent. In some locations, the MEC did not challenge current construction practices.

- In all locations, the appliance aspects of the NAECA minimally increase annual space heating gas use by 1-2 MMBtu ( 2 to $4 \%$ ) because of the reduction in internal heat gains from more efficient appliances. However, these increases are more than offset by improvements in furnace efficiency under the NAECA standards, which reduce by $9 \%$ both annual and peak natural gas consumption for space heating in all climates.

- Annual gas water heating consumption is reduced by $9 \%$ (about $3 \mathrm{MMBtu} / \mathrm{yr}$ ) in all locations as a result of the NAECA. Where gas cooking is assumed, the appliance code reduces annual usage by $4 \mathrm{MMBtu} / \mathrm{yr}$. 
- Appliance efficiency standards, by lowering internal heat gains, reduce cooling energy use by up to $4 \%$ in hotter climates ( $232 \mathrm{kWh}$ in Miami).

- The equipment portion (i.e., changes in SEER) of the NAECA reduces cooling energy consumption by $10-14 \%$, or up to $753 \mathrm{kWh} / \mathrm{yr}$, annually in the hotter climates.

- The thermal envelope codes have a varied effect on cooling. They save up to $\mathbf{1 4 0}$ $\mathrm{kWh} / \mathrm{yr}(5 \%)$ in the south and west, and slightly increase cooling in the north and midwest by $70 \mathrm{kWh}$ to $200 \mathrm{kWh}$ (up to $6 \%$ ). The increase in electricity use is a result of the new balance point temperature established by the insulation levels in the colder climates.

- The non-HVAC electricity savings resulting from the NAECA are $10 \%$ to $15 \%$ of the base case appliance electricity consumption, or an annual average of about 1125 $\mathrm{kWh}$. The appliance savings are greater than the cooling savings from air-conditioner equipment standards in all climates.

- Rate schedules can influence the effectiveness of the thermal and appliance standards. That is, cost savings may be greater even though the annual energy savings are not.

The overall conclusions are that new thermal envelope standards, and appliance and equipment efficiency standards can be effective in reducing annual energy use for both natural gas and electric heating, cooling, and appliance end uses, and in turn, can substantially reduce annual energy costs in many U.S. climates. The overall reductions caused by the thermal standards, the NAECA, and their combined effects will not only make the residential sector more energy efficient, but they will help the nation reduce its emissions of greenhouse gases such as carbon dioxide, which is a by-products of fossil fuel combustion and consumption. 
REFERENCES

1. CABO 1989. Model Energy Code (1989 edition). The Council of American Building Officials, Falls Church, VA.

2. ASHRAE 1990. "ASHRAE Standard: Energy Efficient Design of New Low-rise Residential Buildings. (BSR/ASHRAE 90.2p), Public Review Draft". American Society of Heating, Refrigerating, and Air-conditioning Engineers, Inc., Atlanta, GA.

3. Ritschard, R. L., J. W. Hanford, and A. O. Sezgen 1991. "Single-family Heating and Cooling Requirements: Assumptions, Methods, and Summary Report"', Gas Research Institute. Report No. GRI-91/0236, Chicago, IL.

4. National Appliance Energy Conservation Act of 1987 (P.L. 100-12) and National Appliance Energy Conservation Amendments of 1988 (P.L. 100-357), Washington, DC.

5. National Conference of States on Building Codes and Standards (NCSBCS), 1988. The Energy Directory. NCSBCS, Herndon, VA.

6. Turiel, I., D. Berman, P. Chan, T. Chan, J. Koomey, B. Lebot, M. Levine, J. McMahon, G. Rosenquist, and S. Stoft. 1990. “U.S. Residential Appliance Energy Efficiency: Present Status and Future Directions", Proceedings of the American Council for an Energy Efficient Economy (ACEEE) 1990 Summer Study on Energy Efficiency in Buildings, Asilomar, CA.

7. McMahon, J.E. 1987. "LBL Residential Energy Model: An Improved Policy Analysis Tool' ', Energy Systems and Policy, Vol. 10, No. 1, pp. 41-71.

8. Andersson, B., W. L. Carroll, and M. R. Martin 1986. "Aggregation of U. S. Population Centers Using Climate Parameters Related to Building Energy Use". Journal of Climate and Applied Meteorology, Vol. 25, No. 5, May 1986.

9. Crow, L., 1984. “Weather Yeaĩ for Energy Calculations”. ASHRAE Journal 16 (6): 42-47.

10. Huang, Y.J., R. Ritschard, J. Bull, S. Byrne, I. Turiel, D. Wilson, C. Hsui and D. Foley, 1987. "Methodology and Assumptions for Evaluating Heating and Cooling Energy Requirements in New Single-family Residential Buildings. Technical Support Document for the PEAR Microcomputer Program", Lawrence Berkeley Laboratory Report 19128, Berkeley, CA. 
11. NAHB National Research Center, 1989. "1987 Builder Practices Survey Data". prepared for Lawrence Berkeley Laboratory, P.O. no. 4556710, March 1, 1989.

12. U. S. Department of Commerce, Bureau of the Census, 1980-1989. "Characteristics of New Housing: 1980-1989'. Current Construction Reports, series C25.

13. Energy Information Administration, 1984. Residential Energy Consumption Survey (RECS). U.S. Department of Energy, Washington, D.C.

14. Bluestein, J. and H. DeLima, 1985. "Regional Characteristics and Heating/Cooling Requirements for Single-family Detached Houses." Topical Report GRI-85/164, Gas Research Institute, Chicago, IL.

15. NAHB Research Foundation, Inc. n.d. "Special NAHB Research Foundation Report"'. Upper Marlboro, MD.

16. Sherman, M.H. and D.T. Grimsrud, 1980. "Measurement of Infiltration Using Fan Pressurization and Weather Data", Lawrence Berkeley Laboratory Report 10892, Berkeley, CA.

17. Sherman, M.H, D.J. Wilson, and D.E. Kiel, 1984. "Variability in Residential Air Leakage”. Lawrence Berkeley Laboratory Report 17587, Berkeley, CA.

18. American Society of Heating, Refrigeration and Air-conditioning Engineers (ASHRAE), 1988. "Air Leakage Performance for Detached Single-Family Residential Buildings," ANSI/ASHRAE 119-1988, Atlanta, GA.

19. Labs, K., J. Carmondy, R. Sterling, L. Shen, Y.J. Huang, and D. Parker, 1988. Building Foundation Design Handbook, Oak Ridge National Laboratory Report, ORNL/Sub/8672143/1., Oak Ridge, TN.

20. Fels, M.F. and M.L. Goldberg, 1984. "With Just Billing and Weather Data, Can One Separate Lower Thermostat Settings from Extra Insulation?" In: Families and Energy, (Eds.) B. Morrison and W. Kempton, Institute for Family and Child Study, Michigan State University, East Lansing, MI.

21. Kempton, W. and S. Krabacher, 1987. "Thermostat Management: Intensive Interviewing Used to Interpret Instrumentation Data'. In: Energy Efficiency: Perspectives on Individual Behavior, (Eds.) W. Kempton and M. Neiman, American Council for an EnergyEfficient Economy, Washington, DC.

22. Vine, E., 1986. "Saving Energy the Easy Way: An Analysis of Thermostat Management", Energy 11 (10): 977-984. 
23. American Society of Heating, Refrigeration and Air-conditioning Engineers (ASHRAE), 1981. ASHRAE Handbook of Fundamentals, Atlanta, GA.

24. Energy Information Administration, 1989. Household Energy Consumption and Expenditures 1987, Part 1: National Data. U.S. Department of Energy, Washington, D.C.

25. California Energy Commission, 1980. "Assumptions Used with Energy Performance Computer Programs, Project Report No. 7', California Energy Commission, Sacramento, CA.

26. California Energy Commission, 1985. "Methodology for Calculating Water Heating Energy Pursuant to the Residential Building Standard (Staff Report)", California Energy Commission, Sacramento, CA.

27. U.S. Department of Energy 1985. "Code of Federal Regulations”, 10: Part 430 (Energy Conservation Program for Consumer Products), pp. 58-65.

28. American Society of Heating, Refrigeration and Air-conditioning Engineers (ASHRAE), 1987. Chapter 54. Handbook of HVAC Systems and Applications, Atlanta, GA.

29. Thrasher, W.H., D.W. DeWerth, and B.R. Becker 1990. "Comparison of Collected and Compiled Existing Data on Service Hot Water Use Patterns in Residential and Commercial Establishments; Phase 1 Final Report". ASHRAE research project no. 600-RP, Atlanta, GA.

30. Ritschard, R. L. and Y.J. Huang 1989. "Multifamily Heating and Cooling Requirements: Assumptions, Methods, and Summary Results", Gas Research Institute. Report No. GRI-88/0239, Chicago, IL.

31. L.J. White, S.R. Cumbow and K.L. Sumner 1990. "Electric and Gas Rates for the Residential, Commercial, and Industrial Sectors'. Gas Research Institute Report No. GRI-90/0123.1 and GRI-90-0123.2 (in two volumes), Chicago, IL. 
APPENDIX A: HEATING AND COOLING LOADS TABLES 
Annual and Peak Heating and Cooling Loads Under Efficiency Standards

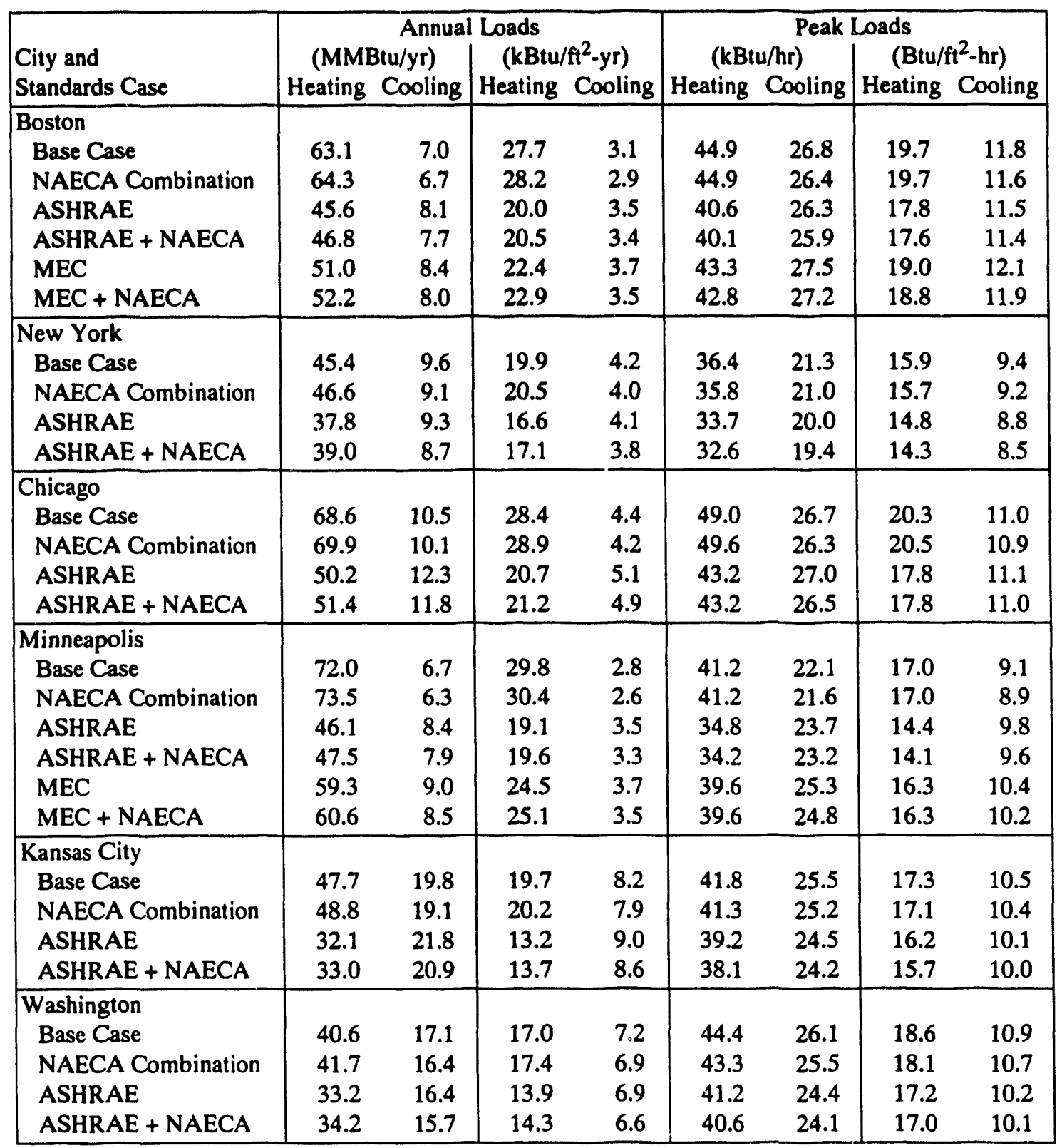

Effects of NAECA on building loads is only from changes in internal gains. 
Annual and Peak Heating and Cooling Loads Under Efficiency Standards (cont.)

\begin{tabular}{|c|c|c|c|c|c|c|c|c|}
\hline \multirow[b]{2}{*}{$\begin{array}{l}\text { City and } \\
\text { Standards Case } \\
\end{array}$} & \multicolumn{4}{|c|}{ Annual Loads } & \multicolumn{4}{|c|}{ Peak Loads } \\
\hline & \multicolumn{2}{|c|}{$\begin{array}{l}\text { (MMBtu/yr) } \\
\text { Heating Cooling }\end{array}$} & \multicolumn{2}{|c|}{$\begin{array}{c}\left(\mathrm{kBtu} / \mathrm{ft}^{2}-\mathrm{yr}\right) \\
\text { Heating Cooling }\end{array}$} & \multicolumn{2}{|c|}{ (kBtu/hr) } & \multicolumn{2}{|c|}{$\begin{array}{c}\left(\mathrm{Btu} / \mathrm{ft}^{2}-\mathrm{hr}\right) \\
\text { Heating Cooling }\end{array}$} \\
\hline $\begin{array}{l}\text { Atlanta } \\
\text { Base Case }\end{array}$ & 25.0 & 18.5 & 10.5 & 7.8 & 38.1 & 23.1 & 15.9 & 9.7 \\
\hline NAECA Combination & 25.7 & 17.7 & 10.8 & 7.4 & 37.5 & 22.7 & 15.7 & 9.5 \\
\hline ASHRAE & 21.8 & 18.2 & 9.1 & 7.6 & 37.5 & 22.4 & 15.7 & 9.4 \\
\hline ASHRAE + NAECA & 22.5 & 17.4 & 9.4 & 7.3 & 36.5 & 22.0 & 15.3 & 9.2 \\
\hline MEC & 25.0 & 18.5 & 10.5 & 7.8 & 38.1 & 23.1 & 15.9 & 9.7 \\
\hline MEC + NAECA & 25.7 & 17.7 & 10.8 & 7.4 & 37.5 & 22.7 & 15.7 & 9.5 \\
\hline Miami & & & & & & & & \\
\hline Base Case & 1.8 & 37.7 & 1.0 & 20.6 & 22.0 & 20.4 & 12.0 & 11.1 \\
\hline NAECA Combination & 1.9 & 35.9 & 1.0 & 19.6 & 22.1 & 19.9 & 12.1 & 10.9 \\
\hline ASHRAE & 1.5 & 37.0 & 0.8 & 20.2 & 20.6 & 19.6 & 11.2 & 10.7 \\
\hline ASHRAE + NAECA & 1.6 & 35.2 & 0.9 & 19.2 & 20.7 & 19.2 & 11.3 & 10.5 \\
\hline Fort Worth & & & & & & & & \\
\hline Base Case & 24.6 & 22.6 & 13.4 & 12.3 & 32.0 & 24.4 & 17.5 & 13.3 \\
\hline NAECA Combination & 25.4 & 21.6 & 13.9 & 11.8 & 32.1 & 24.1 & 17.5 & 13.2 \\
\hline ASHRAE & 22.9 & 22.1 & 12.5 & 12.1 & 30.8 & 23.8 & 16.8 & 13.0 \\
\hline ASHRAE + NAECA & 23.7 & 21.1 & 13.0 & 11.5 & 31.0 & 23.5 & 16.9 & 12.8 \\
\hline MEC & 16.8 & 21.2 & 9.2 & 11.6 & 26.0 & 22.0 & 14.2 & 12.0 \\
\hline $\mathrm{MEC}+\mathrm{NAECA}$ & 17.5 & 20.2 & 9.6 & 11.0 & 26.2 & 21.6 & 14.3 & 11.8 \\
\hline New Orleans & & & & & & & & \\
\hline Base Case & 13.7 & 20.0 & 7.5 & 10.9 & 29.4 & 22.8 & 16.1 & 12.5 \\
\hline NAECA Combination & 14.3 & 18.9 & 7. & 10.3 & 28.9 & 22.4 & 15.8 & 12.2 \\
\hline ASHRAE & 11.9 & 18.9 & 6.5 & 10.3 & 28.3 & 22.1 & 15.5 & 12.1 \\
\hline ASHRAE + NAI & 12.5 & 17.7 & 6.8 & 9.7 & 27.8 & 21.6 & 15.2 & 11.8 \\
\hline Denver & & & & & & & & \\
\hline Base Case & 40.9 & 8.7 & 17.9 & 3.8 & 42.2 & 20.9 & 18.4 & 9.1 \\
\hline NAECA Combination & 42.0 & 8.3 & 18.3 & 3.6 & 41.6 & 20.5 & 18.2 & 9.0 \\
\hline ASHRAE & 31.3 & 8.2 & 13.7 & 3.6 & 39.5 & 19.6 & 17.2 & 8.6 \\
\hline ASHRAE + NAECA & 32.4 & 7.8 & 14.1 & 3.4 & 38.4 & 19.2 & 16.8 & 8.4 \\
\hline MEC & 38.6 & 8.7 & 16.8 & 3.8 & 41.6 & 20.9 & 18.2 & 9.1 \\
\hline MEC + NAECA & 39.7 & 8.3 & 17.3 & 3.6 & 41.1 & 20.5 & 17.9 & 9.0 \\
\hline
\end{tabular}

Effects of NAECA on building loads is only from changes in internal gains. 
Annual and Peak Heating and Cooling Loads Under Efficiency Standards (cont.)

\begin{tabular}{|c|c|c|c|c|c|c|c|c|}
\hline \multirow{3}{*}{$\begin{array}{l}\text { City and } \\
\text { Standards Case }\end{array}$} & \multicolumn{4}{|c|}{ Annual Loads } & \multicolumn{4}{|c|}{ Peak Loads } \\
\hline & \multirow{2}{*}{\multicolumn{2}{|c|}{$\begin{array}{c}\text { (MMBtu/yr) } \\
\text { Heating Cooling }\end{array}$}} & \multirow{2}{*}{\multicolumn{2}{|c|}{$\begin{array}{c}\left(\mathrm{kBtu} / \mathrm{ft}^{2}-\mathrm{yr}\right) \\
\text { Heating Cooling }\end{array}$}} & \multirow{2}{*}{\multicolumn{2}{|c|}{$\begin{array}{l}(\mathrm{kBtu} / \mathrm{hr}) \\
\text { Heating Cooling }\end{array}$}} & \multirow{2}{*}{\multicolumn{2}{|c|}{$\begin{array}{c}\left(\mathrm{Btu} / \mathrm{ft}^{2}-\mathrm{hr}\right) \\
\text { Heating Cooling }\end{array}$}} \\
\hline & & & & & & & & \\
\hline Albuquerque & & & & & & & & \\
\hline Base Case & 25.7 & 6.9 & 13.7 & 3.7 & 29.1 & 13.9 & 15.5 & 7.4 \\
\hline NAECA Combination & 26.7 & 6.4 & 14.2 & 3.4 & 29.0 & 13.5 & 15.4 & 7.2 \\
\hline ASHRAE & 21.5 & 6.5 & 11.5 & 3.5 & 26.9 & 13.1 & 14.3 & 6.9 \\
\hline ASHRAE + NAECA & 22.5 & 6.1 & 12.0 & 3.2 & 27.0 & 12.7 & 14.4 & 6.8 \\
\hline MEC & 25.5 & 6.8 & 13.6 & 3.6 & 29.0 & 13.8 & 15.4 & 7.3 \\
\hline MEC + NAECA & 26.5 & 6.4 & 14.1 & 3.4 & 29.0 & 13.4 & 15.4 & 7.1 \\
\hline Phoenix & & & & & & & & \\
\hline Base Case & 6.7 & 31.7 & 3.6 & 16.9 & 22.4 & 29.4 & 11.9 & 15.6 \\
\hline NAECA Combination & 7.1 & 30.6 & 3.8 & 16.3 & 22.5 & 29.1 & 12.0 & 15.5 \\
\hline ASHRAE & 6.2 & 31.1 & 3.3 & 16.6 & 21.8 & 29.1 & 11.6 & 15.5 \\
\hline ASHRAE + NAECA & 6.6 & 30.0 & 3.5 & 16.0 & 22.0 & 28.8 & 11.7 & 15.3 \\
\hline MEC & 6.7 & 31.7 & 3.6 & 16.9 & 22.4 & 29.4 & 11.9 & 15.6 \\
\hline MEC + NAECA & 7.1 & 30.6 & 3.8 & 16.3 & 22.5 & 29.1 & 12.0 & 15.5 \\
\hline Seattle & & & & & & & & \\
\hline Base Case & 54.6 & 4.3 & 23.9 & 1.9 & 45.4 & 27.1 & 19.8 & 11.8 \\
\hline NAECA Combination & 56.0 & 4.1 & 24.4 & 1.8 & 45.6 & 26.5 & 19.9 & 11.6 \\
\hline ASHRAE & 40.7 & 3.9 & 17.8 & 1.7 & 39.8 & 25.0 & 17.4 & 10.9 \\
\hline ASHRAE + NAECA & 42.0 & 3.8 & 18.4 & 1.7 & 40.0 & 24.7 & 17.5 & 10.8 \\
\hline San Francisco & & & & & & & & \\
\hline Base Case & 25.7 & 1.3 & 11.2 & 0.6 & 29.8 & 24.2 & 13.0 & 10.6 \\
\hline NAECA Combination & 26.7 & 1.3 & 11.6 & 0.5 & 30.0 & 23.8 & 13.1 & 10.4 \\
\hline ASHRAE & 20.3 & 1.2 & 8.9 & 0.5 & 27.9 & 23.0 & 12.2 & 10.0 \\
\hline ASHRAE + NAECA & 21.1 & 1.2 & 9.2 & 0.5 & 28.0 & 22.6 & 12.2 & 9.9 \\
\hline Los Angeles & & & & & & & & \\
\hline Base Case & 11.5 & 3.4 & 5.0 & 1.5 & 27.1 & 29.5 & 11.8 & 12.9 \\
\hline NAECA Combination & 12.0 & 3.2 & 5.3 & 1.4 & 27.3 & 29.3 & 11.9 & 12.8 \\
\hline ASHRAE & 8.9 & 3.3 & 3.9 & 1.5 & 25.0 & 28.2 & 10.9 & 12.3 \\
\hline ASHRAE + NAECA & 9.3 & 3.0 & 4.1 & 1.3 & 25.2 & 27.9 & 11.0 & 12.2 \\
\hline
\end{tabular}

Effects of NAECA on building loads is only from changes in internal gains. 
APPENDIX B: ASHRAE 90.2P THERMAL REQUIREMENTS

55 


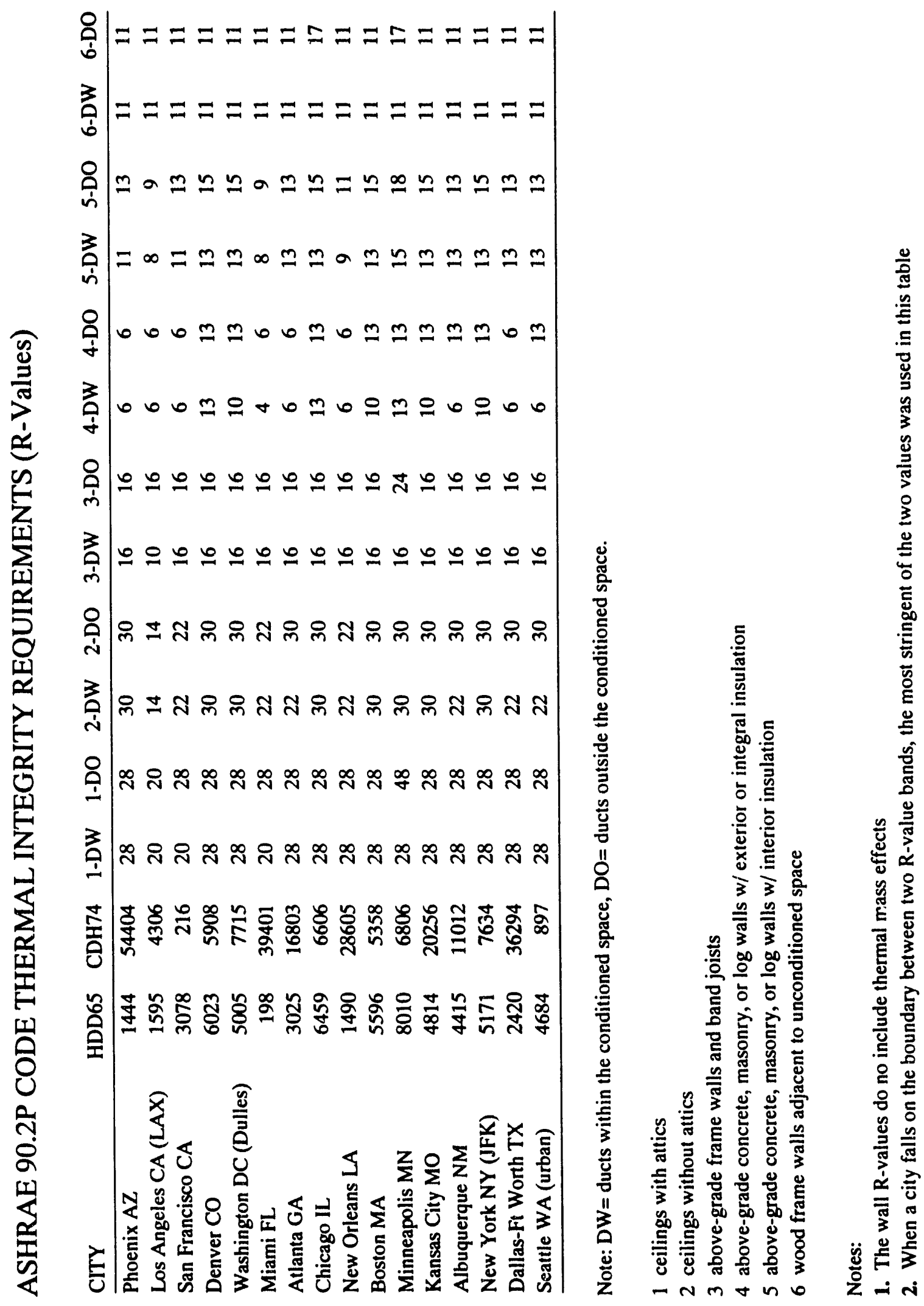




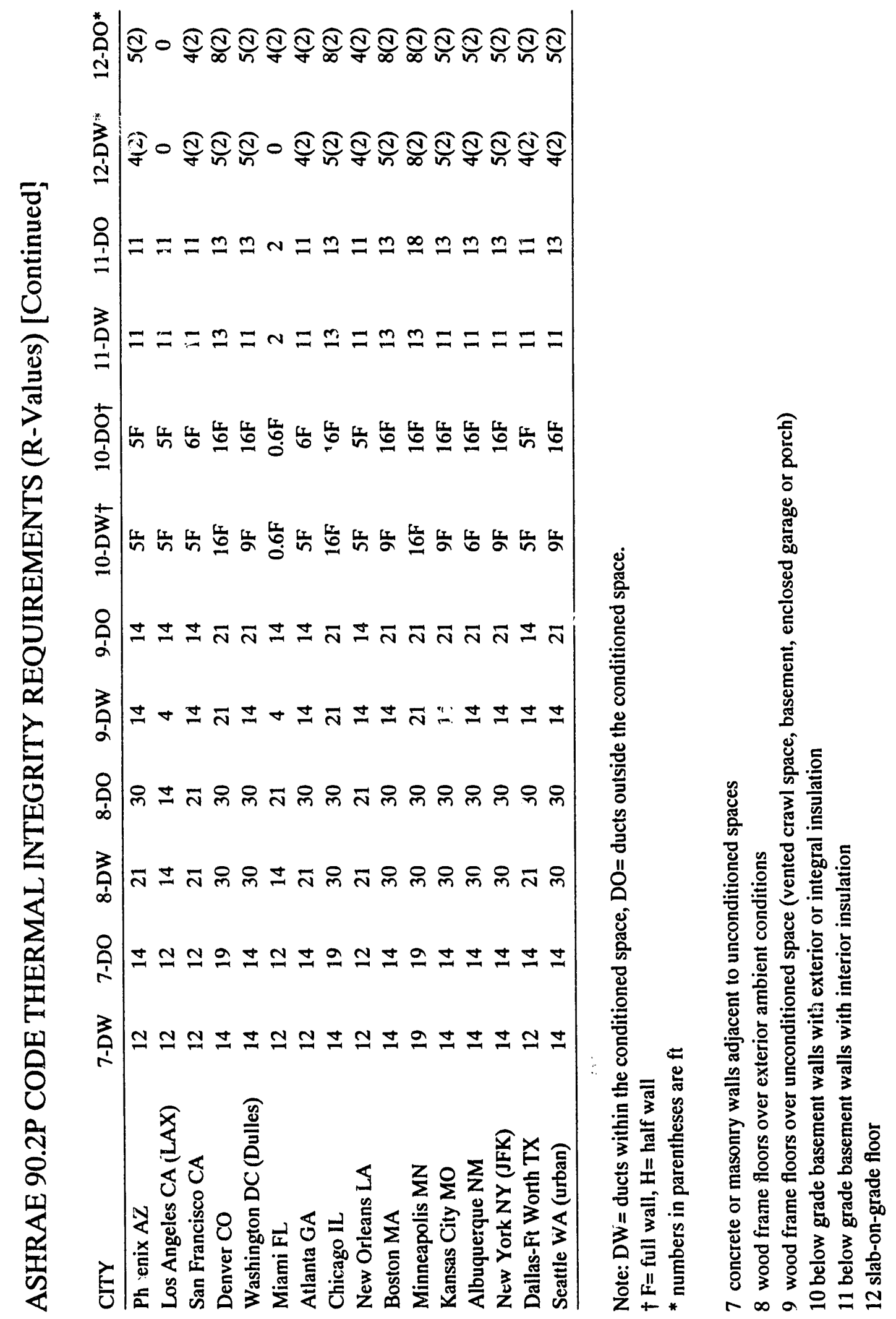




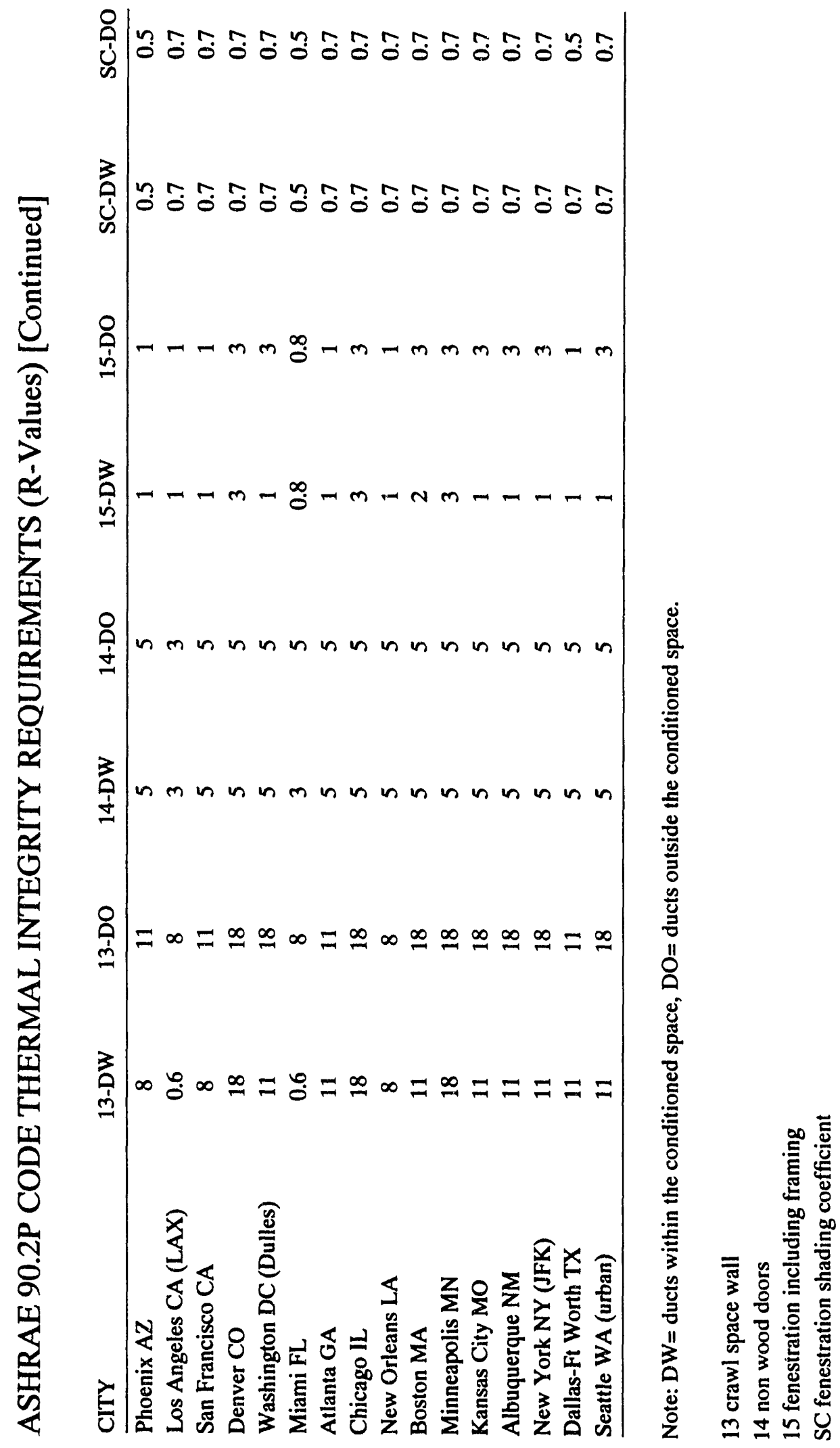


APPENDIX C: 1989 MODEL ENERGY CODE THERMAL REQUIREMENTS 


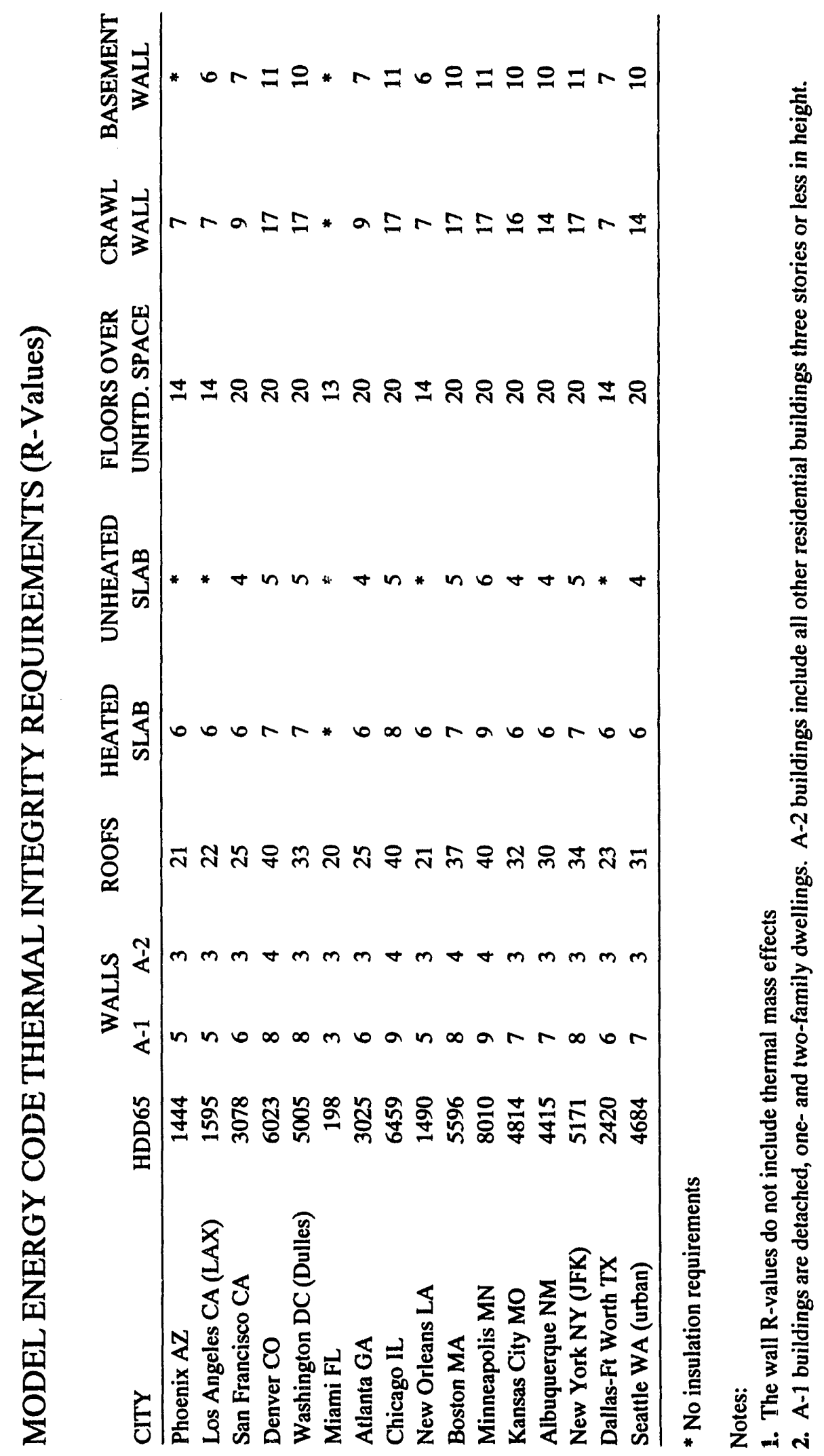



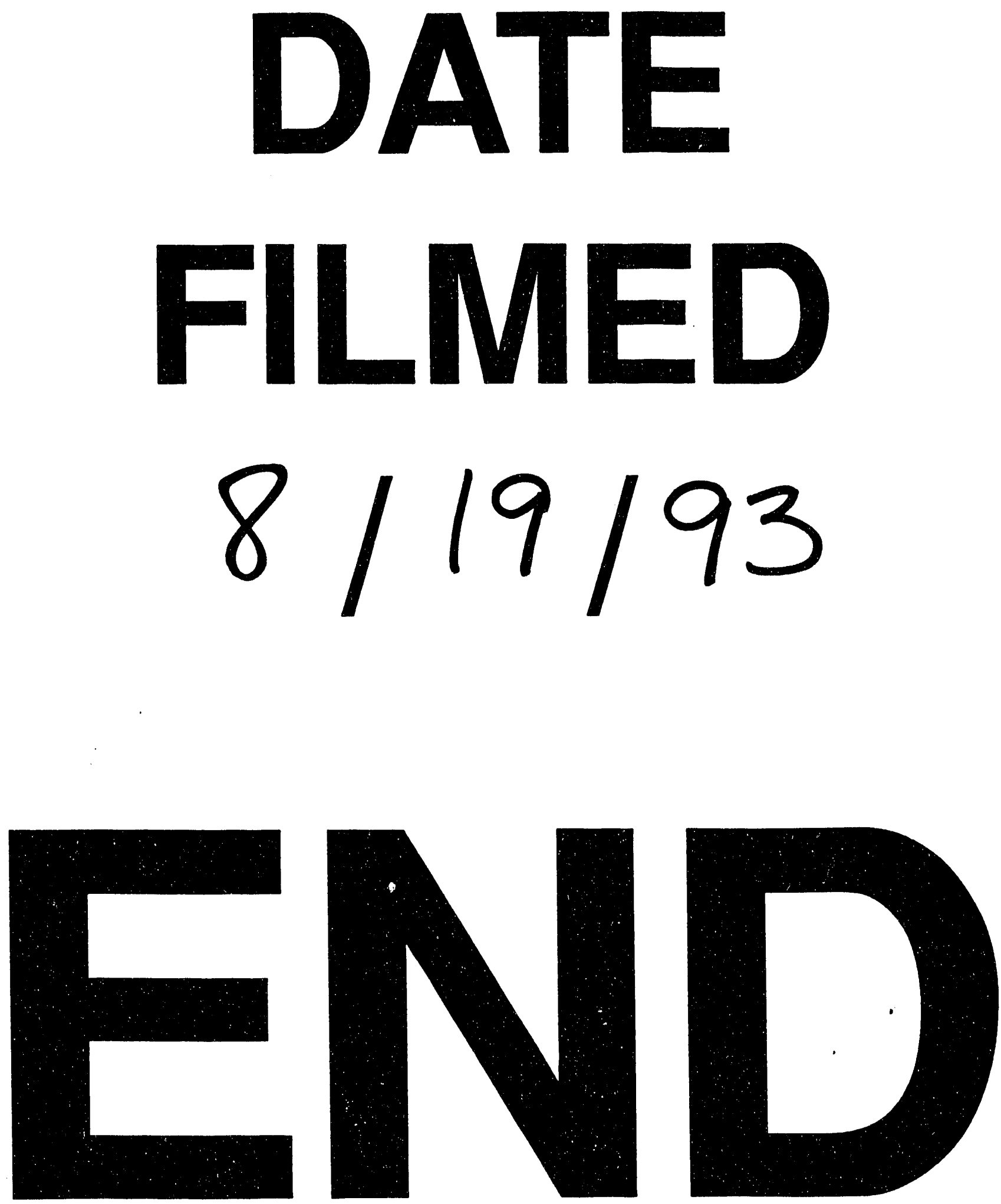
